\title{
Towards a Global Sustainable Information Society (GSIS)?
}

\author{
Christian Fuchs
}

ICT\&S Center: Advanded Studies and Research in Information and Communication Technologies \& Society, Sigmund Haffner Gasse 18, 5020 Salzburg, Austria; christian.fuchs@sbg.ac.at

\begin{abstract}
The development, diffusion, and adoption of new ICTs doesn't automatically result in ecological sustainability, it poses both new opportunities and risks. Embedded into the antagonism between capital and economy it seems like the logical of profitability frequently offsets ecological awareness and hence has negative effects on the realization of positive potentials of ICTs on the environment. Environmental problems are social problems, not technological problems, they are neither caused by science or technology as such, nor can they be solved by science or technology as such.

The discourse on sustainable development shows a shift from the view of nature as an enemy that must be controlled to a view that considers nature as an important pre-condition of human existence that must be treated carefully. In the discourse on sustainability there has been a shift from a focus on ecological issues towards the inclusion of broader societal issues. It has now become very common to identify an ecological, an economic, a social, and an institutional dimension of sustainability.

One can distinguish four types of sustainability concepts based on where in the nature-society-relationship they locate sustainability: ecological reductionism, social projectionism, dualism, man-nature-dialectic.

Both nature and society are self-organizing systems in the sense that they permanently produce themselves. Ecological sustainability means that humans appropriate nature in a way that allows ecological diversity, i.e. the autopoiesis of nature can develop in such a way that nature flourishes, reproduces its subsystems, differentiates itself and produces new qualities, i.e. new ecological life forms and subsystems. Societal sustainability can broadly be defined as a good life for all. A sustainable society encompasses ecological diversity, technological usability, economic wealth, political participation, and cultural wisdom. Ecological sustainability is based on social
\end{abstract}

sustainability and vice versa.

The discourse on the information society has been accompanied by discussion on how to measure the transition towards this new social formation. Institutions such as the EU, the OECD, and the UN, US Census Bureau, the ASEAN, or WSIS are using and discussing various indicators for measurement. These indicators are classified according to various typologies.

There are on the one hand indicators of sustainability that focus on ecological aspects and on the other hand indicators that besides the ecological dimension also take into account broader societal issues. The EU and the UN use a classification scheme that groups indicators according to environmental, economic, social, and institutional aspects. The discourse on sustainability has shifted from an early ecological focus towards the inclusion of economic, political, cultural, and social issues.

The approach suggested in this paper argues that sustainability is a multimodal issue having an ecological, a technological, an economic, a political, and a cultural dimension. Existing sustainability indicators lack aspects of information and ICT, existing information society indicators lack aspects of sustainability. What is needed are indicators that measure the degree to which a sustainable information society has been achieved in the various societal dimensions..

Keywords: sustainability, information society, knowledge society, information and communication technologies, ICTs, sustainable information society 


\section{Introduction}

The aim of this paper is to discuss the notion of a sustainable information society. Questions to which possible answers should be given are:

Which implications do new information and communication technologies (ICTs) and the transition towards the information society have for the ecology and sustainable development?

What is sustainable development?

Which dimensions of sustainability are there and how are they connected?

How are the information society and sustainable development measured?

Which indicators can measure the degree to which a sustainable information society has been achieved?

Part II of this paper focuses on the relationship of new information and communication technologies (ICTs) and sustainable development and advances still more to the concrete in discussing the role of new technologies for the eco-system of the information society. It argues that the information society is inherently a modern society coined by the logic analyzed in part II of this paper. Dimensions of analysis are sustainable development of the information society in context of transport (II.2), business (II.3), ecological cyberprotest (II.4), and the Third World (II.5).

Increasing ecological awareness has advanced the emergence of a discourse on concepts of sustainability and sustainable development. Part III takes a closer look at these discussions and develops a classification of definitions and concepts of sustainability. It first reconstructs the history of the concept (II.1) and then introduces a typology of sustainability approaches (III.2).

Part IV discusses indicators for measuring the information society and sustainability and tries to connect both issues.

\section{ICTs and Sustainable Development}

\section{1. Introduction}

Related to the rising production, use, and diffusion of ICTs there are a lot of hopes, dreams, and myths. This also applies for the ecological subsystem of society where discussions focus on the question if ICTs can advance ecological sustainability, i.e. biological diversity and environmental protection. "Our contention is that, as ICT becomes more sophisticated and more embedded in our organizational structures and everyday life, we are in a better position than ever before to make sustainable development work" (Alakeson/Aldrich/Goodman/Jorgensen 2003: 5). Counter to this quotation I don't think that ICTs automatically advance ecological sustainability, but that ICTs pose both new opportunities and risks for the ecosphere. There is a positive and a negative tendency: ICTs allow the reduction of travelling by doing parts of necessary communications online, it is a medium of ecological communication and the communication and co-operation of the ecological protest movement, but it also contributes to ecological degradation e.g. in the form of computer scrap and the waste and emissions generated in production processes of ICTs. I will discuss the implications of ICTs for sustainability in the areas of transport, business, ecological activism, and developing countries.

\section{2. ICTs, Transport, and Ecological Sustainability}

"Fast, cheap global communications could reduce the need for travel, so pollution levels would fall. (...) The ability to transfer information virtually, at high speed and almost no cost, and to communicate effectively at a distance would allow companies to locate away from established economic hubs, free workers to work from anywhere and, in doing so, reduce the environmental impact of goods and people moving from place to place" (Alakeson/Aldrich/Goodman/Jorgensen 2003: 3f, 9). The question is whether 
private and business Internet communication automatically reduces the need for travelling. This can be the case if people consciously choose to avoid unnecessary travelling and transport by plane and car, but Internet communication also makes it easier to connect people globally and to initiate and maintain social relationships and hence it can also raise the desire or need to meet people face to face more frequently.

Some scientists argue that due to the fact that telework allows knowledge workers to overcome spatiotemporal distances and to work from home the need for transport and hence environmental pollution would be reduced. The same argument can be employed for teleconferencing saying that by substituting personal meetings by teleconferences travelling can be reduced. But teleworkers normally don't work full time at home because they need to stay connected personally and face to face with their social work environment, the number of teleworkers is generally relatively low (in Europe the share of teleworkers in the total labour force ranges from less than 2 per cent to more than 10 per cent, cf. Schallaböck et al. 2003: 9), travelling to work produces only a relatively small share of total carbon dioxide emissions, and working from home doesn't automatically imply less transport because online work can produce new contacts that might generate the need for meeting people personally. Working at home can have negative environmental effects, e.g. people can't go shopping on the way home from work, but might take an extra trip by car from home to shops and supermarkets.

Companies often paint an optimistic picture of the effects of teleworking on the ecosystem, but studies show that although teleworkers frequently reduce their commuting distances "the overall distance travelled for commuting is growing though not very fast. That the last three years represent the highest figures, does not support the thesis which suggests that transport savings have been made because of telework" (Schallaböck et al. 2003: 26). A study of the Wuppertal Institute for Austria, Germany, Japan, the Netherlands, and the US, concludes that "the general experience shows, that growing functionality of and access to ICT correlates with growing demands for business travel. (...) Although the advantages provided by mobile telework are very clear, it obviously may contribute to an expansion of both the number of hours worked, and the number of hours travelled. (...) Individual case studies and panel surveys which are mostly based on small quantities of teleworkers show that teleworkers typically work about 1,5 full days per week at home as an average. As a result they save about 2500 kilometres distance travelled for commuting annually. This is based on single commuting distances, which are estimated to be rather high and far above the average for all employees. (...) Looking from a macro perspective at passenger transport does not reveal a significant influence from home-based telework on the number of commuting trips nor the commuting distances travelled. (...) From the macro view on passenger transport, business trips (and in particular the respective distances travelled) prove to be increasing in number significantly. This does not support the hypothesis of transport saving due to teleconferencing, but emphasises the impression that business trips and the use of enhanced ICT in business grow together" (Schallaböck et al. 2003: 35, 52f).

The European reality seems to be that telework and teleconferencing are simply too unimportant for having positive effects on transport savings and that there are rebound effects from online communication on the increase of travelling. About 5 per cent of the labour force in Europe can be considered as teleworkers, roughly 10 per cent of the working days of the complete European labour force can be considered as home-based telework (Schallaböck et al. 2003: 52). The result of another study is that "homeworkers are spending more time travelling than conventional workers" (Marletta et al. 2004).

Telework and teleconferences certainly pose an opportunity for reducing travelling, but this opportunity has thus far not been adequately realized. What is needed is a conscious commitment of business and individuals to reduce the amount of travels by car and plane. ICTs alone don't solve the problem. The reality of work and life today is that in a flexible economy and society individuals have to be flexible and have to travel long-distances in order to maintain work-related and private social relationships. 


\section{II.3. ICTs, Business, and Ecological Sustainability}

Some scientists argue that the shift from the "industrial society" to the "information society" means that the economy becomes less resource-intensive and that hence there is a "dematerialization" of production that creates a "weightless economy" (Coyle 1997, Kelly 1999, Leadbeater 2000, Quah 1999) that advances ecological sustainability. "On the one hand, there are (in the service sector) the traditional occupations that statisticians call 'community, social and personal services': haircuts, cleaning, babysitting, teaching, nursing, government administration and so on. On the other there are 'high value added' services such as currency trading, creating financial derivatives, software development, gene research or making programmes for satellite television. Most of these are high-technology, depending for their existence on modern computer power and telecommunications. They are also dematerialised, or weightless" (Coyle 1997: 2). The argument here is that knowledge-based industries and services are less resource intensive than industrial production, that ICTs can reduce negative environmental impacts of traditional industries by allowing more efficient ways of production and distribution, that certain products and services could be dematerialized/virtualized which would reduce their environmental impact, that such goods are traded and transported over the Internet which would reduce the amount of physical transport, and that ICTs can increase the efficiency of transportation.

A study of the Wuppertal Institute concludes: "The ICT sector's resource productivity (as measured by several ratios) is clearly higher than the resource productivity of the total economy - for direct as well as cumulated environmental pressures, i.e. the ICT sector is significantly 'cleaner' per unit value added generated. CO2-emissions and energy use per unit gross value added generated is comparably low in the ICT sector. (...) The ICT sector's (...) contribution to overall value added is moderate, ranging from five to eight per cent. The 'old' economy is still significant. (...) Regarding product-based ecommerce, the possible dematerialisation potentials appear to be small. The case study findings suggest that productbased ecommerce might even be more resource intense than traditional retailing business. While information-based ecommerce has the potential to decouple economic growth from resource consumption, significant savings on a macro scale are not expected, for various reasons. First, up to date ecommerce is just another sales channel, built-up and maintained in parallel with the traditional channels. Second, the number of products that can potentially be reduced to an 'informational core' is limited. In the sectors of building, food, clothing and community as well as large parts of health and leisure most products can not be digitised. This leaves only a fraction of the total material intensity, in which information-based ecommerce can potentially contribute to a decoupling. Third, consumer habits and rebound effects are likely to have a counterbalancing influence. Whether, with changed framework conditions, the benefits can outweigh the risks, remains to be seen. (...) Teleshopping (B2C) only has the potential to generate small transport savings. This is because shopping travel represents only a small portion of the overall distances travelled, teleshopping generates additional delivery transport, bigger potential for additional transport due to possible compensating passenger transport and rebound effects“ (Kuhndt et al. 2003: 23, 60, 81).

A study of the World Resource Institute concludes: "These findings indicate that technological progress and restructuring toward service-based economies in the study countries have substantially weakened the link between economic growth and resource throughput. The development of new patterns of economic growth, such as e-commerce, may weaken the link further. However, actual dematerialization has not been achieved. We see here that, despite decoupling between growth rates in GDP and material throughput, quantities of wastes and emissions generated by the study countries have increased in absolute terms over the 21-year study period. (...) Part of the explanation for the continued increase in overall waste quantities lies in the fact that traditional industries, despite their declining relative economic importance are not necessarily declining in terms of their physical operations. In addition, even economies with sophisticated high technology sectors continue to use older generation, inefficient technologies where 
they represent low-cost options. (...) Fossil fuel combustion is the dominant activity of modern industrial economies and is the single largest contributor to material outflows to the air and on land. Most of these flows are hazardous to human health or the environment. Technological advances and economic restructuring have contributed to significant decoupling between rates of economic growth and material throughput but they have not achieved any overall reduction in resource use or waste volumes" (WRI 2000: 19, 41).

The reality of dematerialization seems to be that fully virtualized products and the ICT sector constitute only a small portion of the economy, that the total resource use of the economy is constantly rising, and that hence thus far there has not been a massive "greening" of production and consumption induced by knowledge products and ICT. It is not true that "economic value is dematerialising" (Coyle 1997: 1). Postindustrial capitalism as a dematerialized ecologically sustainable economy is a "dangerous myth" (Foster 2002: 24). Alain Touraine has argued in this context that the information society is a "hyperindustrial society" (Touraine 1988). It is not a new society that is characterized by immaterial goods, but a new phase of development of capitalism that is both continuity and discontinuity of industrial capitalism and has emergent qualities such as the central importance of cognitive, communicative, and co-operative labour.

The knowledge economy is not an economy of invisible and intangible goods, there indded are many physical information commodities that are transported and sold. Ursula Huws (2001) argues that in capitalism there is a major tendency to transform services into physical products (commodification, cf. Fuchs 2005, Fleissner 2005) because with the help of the latter capital accumulation would be easier to achieve than with the first due to higher potentials for technological rationalization and outsourced/globalized production.

Another argument is that certain products and services can be entirely virtualized and transported in digital format over the Internet and that hence material and energy savings can be made. E.g. the Wuppertal Institute (Türk et al. 2003) found out in an analysis that downloading a CD over the Internet is 2,5 times as resource efficient as buying it in a music store. This way savings concerning energy and matter in production and transport surely can be made. But many users have the habit of not only storing files on their computers, they rather choose to burn music files on CDs because they prefer to play music on their CD players. Hence there are again material and energy impacts. MP3 players that are portable and can be connected to a hi-fi system surely pose a good alternative that to a certain extent allows resource savings, but the example shows that virtualization doesn't automatically result in ecological sustainability. The same is true for books, journals, and newspapers. If they are distributed in digital format online resource savings in production and distribution can be made. Also new flexible production technologies that are based on just-in-time-production (e.g. books on demand) allow resource savings. But almost no one wants to read a book or a whole newspaper online because it is not very comfortable to read on screen, therefore many people print out articles or whole books which results in a high consumption of paper, toner, and ink. There are certain alternatives such as e-paper that can be reused, but companies thus far have not widely supported reusable or eco-friendly equipment (such as e-paper, the "green PC", or refillable ink cartridges for printers) because reusable computer equipment is not only less resource-intensive, but might in the long-term also be less profitable. "The PC as the modern form of a typewriter and in particular the PC used as a medium to access e-mail, WWW and other Internet services do in fact have the potential to reduce paper consumption. (...) However, as the reader may know from every-day experience, the induction effect offsets the other effects by far, because today's PC and printer technology enables the user to print out hundreds of pages with just a few mouse clicks. Therefore, all in all, ICT contributes to the same general trend for paper that has been observed for the past 60 years" (Hilty/Ruddy 2000: 6). The antagonism between capitalism and ecology has thus far also had negative influences on companies' support for ecologically sustainable ICT equipment. The use of recyclable and reusable equipment could indeed reduce the environmental impact of ICTs, but for doing 
so the logic of capital accumulation needs to be subordinated under ecological and social awareness. The relationship of ICTs and sustainability is not only a question of ethical consumerism, but also one of corporate social and ecological responsibility. In capitalism not those technologies that most benefit society and ecology are promoted, but those that enable capital accumulation. Hence it is e.g. not solar or wind energy or the reusable computer that are promoted, but nuclear energy, fossil fuels, the automobile, and non-renewable computer equipment. "In recession times, decision-makers try to survive. Questions beyond the survival of their companies do not interest them at all; most common recipe: replace people by machines and save money, i.e.: jobs are played against profits and (ecological) reforms" (Mettler 1997: 7). As long as a company is profitable, it might be open-minded for ecological and social goals, but capitalism is based on competition and economic crisis is an inherent feature of the system, hence in the end in many cases the logic of profit will outstrip social and ecological awareness.

Moore's Law says that the speed of computers doubles every 18 months. Thus far this law has proven true. It results in a fast moral depreciation of computers and people frequently buy new computers in order to participate in technological progress. For ecological sustainability we don't necessarily have to slow down technological progress, but the way hardware is manufactured and diffused surely have to change because millions of people continuing to buy a whole new computer each two or three years is detrimental to reaching ecological goals. Advances in chip technology today (under capitalist conditions) result in an increasing reduction of the life span of computers. The average lifetime of a business PC is 2-3 years, the one of a mobile phone 18 months in Europe (EITO 2002: 256). What is needed are reusable, recyclable, and upgradeable computer hardware and periphery.

One should also add that ICTs are industrial products, their production and disposal generates waste and emissions. The knowledge society is not an immaterial society, but a new phase in the material reality of capitalism. It requires a large material infrastructures made up by computers, periphery, servers, routers, switches, network cables, etc. The hardware industry makes profit by selling computers and periphery. If computers were used for a longer time or if it were increasingly possible to renew only certain parts in order to come up to date with technological progress and not having to buy a whole new computer, environmental improvements could indeed be made. But his would require a step away from the logic of profitability towards the logic of ecological sustainability. Hence it would mean to accept lower profits in order to protect the environment. Such moves are possible, but they contradict the dominant economic logic. If corporate social responsibility shall not only be ideology, corporations must be ready to go beyond and to question to a certain extent capitalist logic.

The Internet runs only by consuming energy. The Wuppertal Institute found that in 2000 the Internet accounted for 5 per cent of Germany's total energy use (Barthel et al. 2000). The Internet not only is based on a material infrastructure, it also consumes energy that constitutes another material aspect of the information society. A study by the Fraunhofer Institut für Systemtechnik und Innovationsforschung in cooperation with the Centre for Energy Policy and Economics (2005) has found out that ICTs in business and households account for about $8 \%$ of total energy use in Germany. It is estimated that until 2010 ICT energy use will rise from 38 TWh (2001) to 55,4 TWh (ibid.: 275). Especially television sets, hi-fi systems, computers, servers, mobile phone infrastructure networks, mobile phones and fixed phone lines are considered as being very energy-intensive (ibid.). There are technological possibilities to reduce the energy consumption of television sets and monitors (by using LCD monitors and television sets and selling such machines at reasonable prices) as well as computers (by including components that automatically detach computers from energy supply if they are not used for a certain time, Switched Mode Power Supply). But the interests of the energy industry might be detrimental to establishing "green ICTs" because high amounts of energy use mean high profits, what is needed are political pressure and unified laws that define minimum standards of energy efficiency of ICTs and require producers to include energy 
consumption labels on ICTs. This might have negative consequences on profitability, but if sustainability shall be achieved the domination of society by economic logic must be challenged.

The miniaturization of ICTs doesn't automatically result in less environmental impacts because ICT production itself produces wastes and toxic emissions. ICT equipment such as personal computers or mobile phones contains toxic substances such as lithium or cadmium batteries. Environmental performance assessments of computer technologies show that the latter doesn't heavily reduce material outputs, the production of one PC requires 16-19 tonnes of material resources and more than $5000 \mathrm{kWh}$ energy, the emission of the production of one piece include $60 \mathrm{~kg}$ waste, $1850 \mathrm{~kg}$ carbon dioxide, $2 \mathrm{~kg}$ sulfur dioxide, and $1 \mathrm{~kg}$ nitrogen oxide (Grote 1996). "One study showed that the production of the average computer chip requires 45,46 litres of water, used primarily for washing. One chip plant in the USA uses between 4,5 and 13,5 million litres of water a day. (...) A study for the European Union in 1998 suggested that the production of a personal computer, including material production, manufacture and distribution, would lead to the release of 0,19 tonnes of greenhouse gases, $36 \mathrm{~kg}$ of overall waste, and require 3,6 GJ of energy" (EITO 2002: 255). In Germany 15 per cent of electronic waste is computer waste (Briefs 2000: 19), the EU produces 6 million tonnes of waste of electrical and electronic equipment a year (EITO 2002: 256). "Der Gesamtprozess der Informatisierung (...) ist durch ein Dilemma geprägt: Einerseits erlauben die luK-Techniken, vor allem in den Betrieben einen wirksameren Umweltschutz zu erreichen. Andererseits tragen ihre produktivitätssteigernden Effekte zu weiterem Wachstum und damit zur Umweltbelastung und -zerstörung bei. (...) Festzuhalten ist, dass - im Gegensatz zur gelegentlich geäußerten Ansichft - die luK-Techniken nicht an und für sich saubere, oder gar umweltfreundliche Techniken sind“ (Briefs 2000: 10, 20).

\section{II.4. Ecological Online-Communication and Ecological Cyberprotest}

The ecological movement like other protest movements makes use of ICTs in order to spread environmental information, raise environmental consciousness, co-ordinate environmental protest online, and protest against ecological degradation online. Hence there is a cognitive, a communicative, and a cooperative dimension of cyberprotest (Fuchs 2006). With the help of the Internet NGOs can organize protests against environmental degradation offline and online.

Also companies are increasingly providing information and reports on their environmental and social performance online because they are pressured by civil society to show ecological awareness. It remains an open question to which extent such information is ideological or reflects real material changes in patterns of production and consumption. The problem with eco-reports of companies published on the Internet frequently is that these analyses are not conducted and written by external observers such as NGOs, but by representatives of the companies themselves. Furthermore there is often a difference between ideas and material reality, companies often argue that they support ecological and social sustainability, but ideas are easily voiced, real changes much harder to achieve.

Figure 1 shows an example of ecological cyberprotest: On the website of Friends of the Earth UK it is possible to sign online petitions (in this case one that calls Tony Blair for ending G8 subsidies for oil and redirecting this money to providing renewable energy) that are automatically sent to the relevant stakeholders per e-mail. The Green Peace Cybercentre is the online-community of Greenpeace (http://act.greenpeace.org, http://act.greenpeace.org/cl2/de/de/actions), on this website cyberactivists can sign online petitions, send e-cards, and discuss Greenpeace-related topics in online discussion boards. In the petition section it is possible to generate petition letters that are sent per e-mail (cf. figure 2). These examples show that NGOs belonging to the ecological movement increasingly make use of cyberprotest. Cyberprotest seems to be an aspect of the information society that has positive influence on the societal diffusion of ecological information. 
Strategies for sustainable development "depend critically on awareness, trust, coordination and mechanisms for dialogue" and hence are in need of "effective communication" (Dalal/Bass 2002: 226). Environmental Informatics is concerned with developing computer applications that allow the monitoring, simulation, modelling of environmental processes and the storage, assessment, and communication of environmental data with the help of databases (environmental information systems) (Junker/Lang 2002). Environmental information system, environmental reporting, and environmental information on the World Wide Web can provide public information to environmental issues, concerns, and data and support learning and education strategies for making the ideas and possible practices of sustainable development more widely known. "In order to improve awareness, change attitudes and encourage action on sustainable development, various information products will be required, notably: documents and audiovisual, events, networks, databases, electronic media, and mass media“" (Dalal/Bass 2002: 236).

Reports on Shell's environmental and social impacts are available on the company's website. In the "Shell Report 2004" (http://www.shell.com/home/Framework?siteld=shellreport2004-en) the corporation e.g. argues: "In 2002, the most recent year for which international data is available, the Group produced energy products that delivered nearly 11.7 exajoules of energy. That was 20 times the power needed to provide electricity, heating and transportation for London, and equivalent to $3.9 \%$ of the world's final energy consumption. Our customers emitted an estimated 763 million tonnes of CO2 using these energy products. We released a further 111 million tonnes of $\mathrm{CO} 2$ and other GHGs making them. This is calculated on an equity ownership basis, including our share of joint ventures which we do not operate. Together, this is equivalent to $3.6 \%$ of global $\mathrm{CO} 2$ emitted from the combustion of fossil fuels. We recognise that our response to climate change means more than reducing our own emissions. A shift to lower carbon-emitting energy products is also needed, so the rapid rise in energy use does not bring an equally big increase in GHG emissions. Expanding our natural gas business will help. In the longer term, so will our efforts to lower the costs and increase the use of biofuels, wind and solar power, and hydrogen, and to develop efficient ways to capture and safely store the $\mathrm{CO} 2$ from fossil fuels But both meeting the energy supply challenge and first slowing, and then eventually reversing, the rise in carbon emissions will remain a major challenge for energy producers and users alike". Shell admits that $\mathrm{CO} 2$ emission is a serious environmental problem and promises that its won CO2 emissions will be 5\% lower in 2010 than in 1990. It also realizes that alternative energy forms are needed and argues that it will support alternative technologies in the long-term. The latter could be empty promises because it is obvious that the consumption of fossil fuels produces money profits for Shell, hence the company benefits from the ecological degradation caused by fossil fuels. Shell presents itself in this report as a company that is concerned for ecological and social sustainability. Greenpeace in its report on corporate crimes paints a much less optimistic picture of Shell: "Shell Chemicals started production of the "drins" (endrin, dieldrin and aldrin) in 1952 - ending completely in 1990. [...] As a result of drin production in Pernis, the Netherlands, river sediments, residential areas and several dumpsites were severely polluted. The production of drins by Shell in the US at the Rocky Mountain Arsenal has also led to a huge pollution scandal. Leaking basins and pipes have contaminated 70 square kilometres of land. The pollution caused by the Shell drins-producing plant in La Paulínia, Brazil, is described in separately in this report. Exposure of people to drins has led to many poisonings and deaths. Many incidents have been reported, for example the consumption of bread made from endrin-contaminated flour that affected at least 936 people and caused 26 deaths. Large quantities of expired, prohibited and unwanted drins are in storage worldwide8. In many cases the storage facilities are inadequate and packaging of the drins are in very bad condition. Exposure of workers, local communities and the environment to these very toxic pesticides cannot be excluded and accidents with these old pesticides can easily happen. Although the use of drins has been virtually banned in the USA and the Netherlands since the late 1970s due to known toxic effects, Shell continued the production and sales to industrialising countries up until 1992. Today, the drins are also banned by the United Nations (UN) because they are associated with the incidence of cancer and reproductive, endocrine and immune system dysfunctions. [...] The existence of stockpiles of these 
banned and obsolete pesticides in deteriorating conditions is known to Shell and other pesticide producing companies. Shell has removed some of the drin stockpiles and drin waste from several African countries. But the pesticide companies including Shell refuse to take full responsibility for the complete removal of stockpiles. Several known stockpiles, including drins, have not been treated and continue to put local communities and environment at great risk. Only in the US and partly in the Netherlands has Shell had to pay a share of the costs. As far as is known, Shell has not been held liable for poisoning or for the costs of removal of obsolete pesticide stockpiles. This case shows that Shell continued the production and sales of drin pesticides long after the company knew the product was very toxic and affected peoples' health. However, it seems almost impossible now to hold Shell liable for the negative impacts of the product. There is no global instrument available to make Shell accountable to the removal of banned and obsolete pesticides stockpiles including drins. Pesticides companies should be obliged to take full responsibility for the removal and safe destruction of the obsolete pesticides in industrialising countries" (Greenpeace 2002: 68f). Virtual reality produces a difference between actual and virtual reality, what exists in virtual reality must not necessarily correspond to actual reality, but can be as Jean Baudrillard (1983) has stressed a simulation and hyper-reality. Due to the information overload, information found in the World Wide Web is not automatically true (according to facts), but can be a simulated reality. Corporate online reporting shed a positive light on certain companies by leaving out certain information and emphasizing other information. The Shell-example shows that Internet reporting is related to the problem of simulation and hyperreality in Cyberspace.

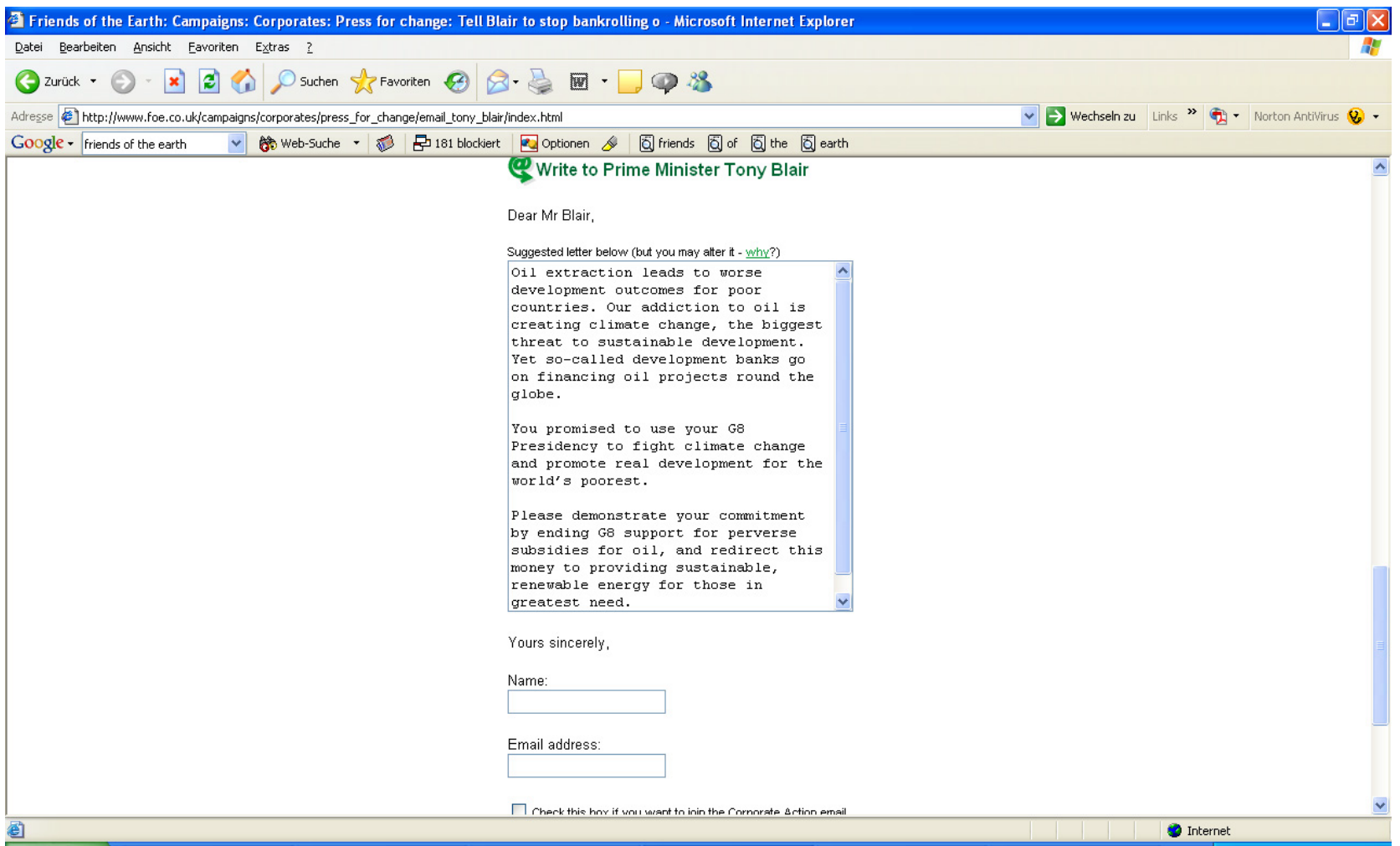

Fig. 1: Friends of the Earth: Environmental Cyberprotest 


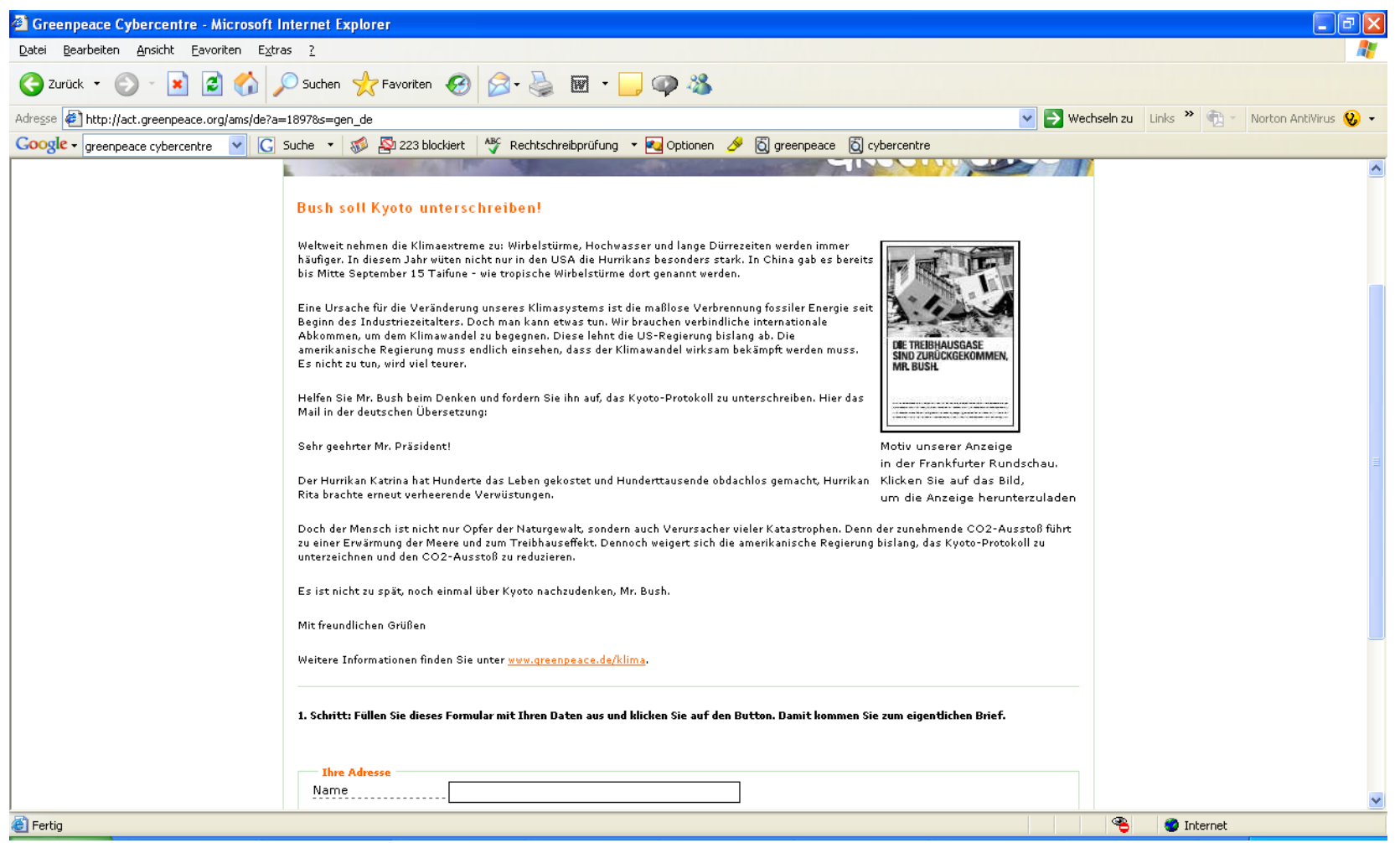

Fig. 2: Greenpeace Germany Cybercentre: Online Petition ("Bush Shall Sign Kyoto!")

Marletta et al. (2004) have shown in a study that political participation, education, and Internet usage are positively related to environmental sensibility and that "those internet users with the strongest environmental sensitivity are those who are most likely to have used the net to access environmental information". The Internet is mainly a sphere of commerce, sex, and entertainment where ecological information and communication is only a minority issue. Hence I think that ecological knowledge on the Internet is today more an insider affair than one of raising public ecological consciousness.

\section{II.5. ICTs, Sustainability, and the Third World}

In the book "Knowledge Societies. Information Technology for Sustainable Development" edited by Robin Mansell and Uta Wehn there is a chapter on "The Potential Uses of ICTs for Sustainable Development" that wants to focus on ICT applications that could assist developing countries to reap the "social and economic benefits associated with extremely rapid innovation in advanced ICT-based goods and services" (Mansell/Wehn 1998: 82). Sustainable development is here understood as social and economic development. The chapter lists and discusses a number of ICT applications in the areas of etravelling, e-government, e-transport, e-health, e-education, e-inclusion, and e-learning. These are technologies that today are mainly developed in Western countries and benefit the latter. The Third World is not only largely excluded from wealth, but also from technological progress. In 1999 there was 56 billion dollars in Western foreign aid for the Third World and the latter paid 136 billion dollars debt service to Western countries (Fuchs 2002: 370). Hence in total there was a value transfer from developing countries to developed countries and hence human aid in its current form is more ideology than real help. Although Africans make up $14,0 \%$ of the world population, Africa only accounts for $1,7 \%$ of the number of global Internet users (data from July 2005, source: World Internet Usage Statistics, http://www.internetworldstats.com/stats.htm).

I think what is needed for improving the situation of developing countries is on the one hand radical global redistribution of wealth starting with measures such as the increase of human aid, basic income for the absolute poor in the world, the elimination of debt burdens on Third World countries, and on the other 
hand a non-colonizing technology that is adapted to the needs of people in Third World countries and integrates their traditional knowledge and technologies. The authors of the chapter mention that "policy measures are needed to address the key areas within each country's overall development strategy that could benefit from the use of ICT applications to promote initiatives that will generate financial resources" (Mansell/Wehn 1998: 95) and that "a major goal of initiatives to implement ICT applications in developing countries is to help to alleviate poverty" (ibid.: 98). But this chapter creates the image that solutions to the problems can be provided by Western technologies that are applied in Third World countries. This position is one of cultural imperialism that neglects that local and traditional ideas are of high cultural importance in solving the problems of the Third World and to avoid creating the impression of cultural imperialism. Western habits, colonialism, and post-colonial practices are part of the causes of the problems that Third World countries are facing today. What is hence needed in addressing issues such as poverty and ICTs in the Third World is unity in diversity management.

In the Declaration of Principles of the World Summit on the Information Society (WSIS) passed in Geneva in 2003 technology transfer and ICT manufacturing is understood as a means for achieving a sustainable information society for developing countries: "33. To achieve a sustainable development of the Information Society, national capability in ICT research and development should be enhanced. Furthermore, partnerships, in particular between and among developed and developing countries, including countries with economies in transition, in research and development, technology transfer, manufacturing and utilization of ICT products and services are crucial for promoting capacity building and global participation in the Information Society. The manufacture of ICTs presents a significant opportunity for creation of wealth. [...] 43. Sustainable development can best be advanced in the Information Society when ICT-related efforts and programmes are fully integrated in national and regional development strategies. We welcome the New Partnership for Africa's Development (NEPAD) and encourage the international community to support the ICT-related measures of this initiative as well as those belonging to similar efforts in other regions. Distribution of the benefits of ICT-driven growth contributes to poverty eradication and sustainable development." (WSIS 2003a, Principles 33, 43). A sustainable information society is here considered as one where ICTs promote participation and poverty eradication. Furthermore sustainable production and consumption patterns, usability, e-health, and e-learning are considered as aspects of a sustainable information society: " 51 . The usage and deployment of ICTs should seek to create benefits in all aspects of our daily life. ICT applications are potentially important in government operations and services, health care and health information, education and training, employment, job creation, business, agriculture, transport, protection of environment and management of natural resources, disaster prevention, and culture, and to promote eradication of poverty and other agreed development goals. ICTs should also contribute to sustainable production and consumption patterns and reduce traditional barriers, providing an opportunity for all to access local and global markets in a more equitable manner. Applications should be user-friendly, accessible to all, affordable, adapted to local needs in languages and cultures, and support sustainable development. To this effect, local authorities should play a major role in the provision of ICT services for the benefit of their populations" (WSIS 2003a, Principle 51).

The WSIS Plan of Action (WSIS 2003b) argues that for achieving a sustainable information society governments, businesses, civil society, and international and regional institutions must take responsibility. WSIS argues in favour of a mixed strategy of political practice and economic investment for achieving a sustainable information society. Government should devise national strategies for digital inclusion, promote public access, e-government, e-business, e-learning, e-health, e-employment, e-environment, eagriculture, e-science, etc. For achieving a sustainable information society in developing countries, the WSIS Plan of Action argues on the one hand that debt cancellation is needed, on the other hand that more private national and international markets for ICTs should be provided by developing countries. "D2. c. For those developing countries facing unsustainable debt burdens, we welcome initiatives that have been undertaken to reduce outstanding indebtedness and invite further national and international 
measures in that regard, including, as appropriate, debt cancellation and other arrangements. Particular attention should be given to enhancing the Heavily Indebted Poor Countries initiative. These initiatives would release more resources that may be used for financing ICT for development projects. d. Recognizing the potential of ICT for development we furthermore advocate: i. developing countries to increase their efforts to attract major private national and foreign investments for ICTs through the creation of a transparent, stable and predictable enabling investment environment; ii. developed countries and international financial organisations to be responsive to the strategies and priorities of ICTs for development, mainstream ICTs in their work programmes, and assist developing countries and countries with economies in transition to prepare and implement their national e-strategies. Based on the priorities of national development plans and implementation of the above commitments, developed countries should increase their efforts to provide more financial resources to developing countries in harnessing ICTs for development; iii. the private sector to contribute to the implementation of this Digital Solidarity Agenda“ (WSIS 2003b).

What is missing here is the insight that markets don't automatically eliminate poverty because they don't determine how wealth is distributed. Hence what is needed are regulatory practices that ensure that the benefits from ICT and economic production can be shared by all. Capital here is assessed only as a positive factor in achieving sustainable development. WSIS assesses IC markets as very positive means of advancing social sustainability, it neglects aspects of political regulation of the economy and income distribution and gives priority to economic logic.

\section{II.6. Conclusion of Part II}

The development, diffusion, and adoption of new ICTs doesn't automatically result in ecological sustainability, it poses both new opportunities and risks. Embedded into the antagonism between capital and economy it seems like the logical of profitability frequently offsets ecological awareness and hence has negative effects on the realization of positive potentials of ICTs on the environment. What is needed are conscious decisions and political practices that put human interests first and create a social context where ICTs can be used in socially and ecologically sustainable ways.

Environmental problems are social problems, not technological problems, they are neither caused by science and technology as such, nor can they be solved by science or technology as such. Science and technology have due to their unsustainable social design contributed to environmental degradation, they have been turned into destructive forces by social forces. Heavy promotion of computer usage is not an appropriate means and automatism for achieving ecological sustainability, the latter requires alternative models of economic production. If humankind is interested in a sustainable society, the destructive character of the economy must be sublated, new models of economic production and social relationships are needed.

\section{A Classification of Definitions and Concepts of Sustainability/Sustainable Development}

\section{1. Introduction: A Short History of the Concept of Sustainability}

At the beginning of the third millennium the term sustainable development has gained importance well beyond ecological movements. The global social and ecological problems of society have resulted in an increasing awareness that in science has caused the development of new theories, concepts, and practices. These problems include poverty, inequalities in access to resources such as shelter, food, clean water and air, and employment, lack of medical supplies and social security, low life-expectancy, low enrolment and completion rates in primary, secondary and higher education, lack of political participation, gender inequality, violent conflicts, the over-use of non-renewable resources, ecological degradation, pollution, etc. in many parts of the world. Such problems are global in the sense that they affect the lives 
of all humans worldwide. E.g. global warming that is caused by the fact that human activities are now placing more carbon dioxide into the atmosphere more quickly than the natural sinks of the gas (oceans and green vegetation) can remove through processes of diffusion and photosynthesis, causes problems such as the slow melting of glaciers and ice-sheets, the increase of global mean temperature, and the vulnerability of society to natural disasters that pose risks for all humans. The side-effects of modernization are risks and non-knowledge, some scientists hence argue that we live in a high risk society (Beck 1986, 1999).

In the first UN Development Decade of the 1960s policies and thinking focused on economic growth and the application of science and technology as the route to prosperity in the underdeveloped world. Since it became clear in the 1970s that inequality between and within countries had worsened, there has been increasing awareness that additional policies are needed. People began to realize that there are deep-seated social and ecological problems of society that have become global problems that negatively influence human existence on earth. Text such as "The Population Bomb" (Ehrlich 1968), "Blueprint for Survival" (Goldsmith et al. 1972), and "The Limits to Growth" (Meadows et al. 1972) showed that there are limits to the dominant, expansive forms of development of modern society that cause global problems and that urgent actions are needed. An increasing number of people argued that development must be shaped in such a way that society reduces the energy-intensity of production and consumption and that poverty can be eradicated. At the 1972 UN Conference on the Environment in Stockholm environmental issues were set on the international political agenda. In 1973 following the Stockholm conference the United Nations Environment Programme (UNEP) was established. As another result of the conference numerous national environmental protection agencies were established.

The changes of the 1970s caused the increasing acknowledgement of the interdependence of development and social as well as ecological issues. By the early 1980 s sustainable development had begun to gain wider public attention, chiefly as a result of the publication of Robert Allen's "How to Save the World" (1980) and Lester Brown's "Building a Sustainable Society" (1981). In 1984 the Worldwatch Institute published its first annual "State of the World" report that provided a global perspective on the relation between the world's resource base and the dynamics of economic development. It concluded that "we are living beyond our means, largely by borrowing against the future".

In the early 1980s the World Commission on Environment and Development (WCED) was charged with formulating proposals for dealing with problems of environment and development. The General Assembly of the UN asked the WCED to propose long-term environmental strategies for achieving sustainable development by the year 2000 and beyond, to recommend ways concern for the environment may be translated into greater co-operation among developing countries and between countries at different stages of economic and social development, to consider ways and means by which the international community can deal more effectively with environmental concerns, and to help define shared perceptions of long-term environmental issues and the appropriate efforts needed to deal successfully with the problems of protecting and enhancing the environment, a long-term agenda for action during the coming decades, and aspirational goals for the world community (WCED 1987: ix).

In 1987 the WCED published the "Brundtland Report" (named after its Chair, the former Prime Minister of Norway, Gro Harlem Brundtland; WCED 1987) that gave much attention to the challenge of overcoming poverty and meeting basic needs and to integrating the environment into economic decision-making. The WCED defined sustainable development as "development that meets the needs of the present without compromising the ability of future generations to meet their own needs. Sustainable development is not a fixed state of harmony, but rather a process of change in which the exploitation of resources, the direction of investments, the orientation of technological development and institutional changes are made consistent with future as well as present needs" (WCED 1987: 43). The WCED created the first framework for concerted action to protect the Earth's life support systems while promoting both economic and social 
justice. The WCED identified seven core issues of sustainability: population and development, food security, species and ecosystems, energy, industry, and the urban challenge. It argued that the pursuit of sustainable development requires political participation, an economic system that provides solutions for tensions arising from disharmonious development, the preservation of the ecological base, sustainable patterns of trade and finance, and flexible and self-correcting administrative systems. It pointed out that ecological, economic, political, and social issues are interrelated. "Ecology and economy are becoming ever more interwoven - locally, regionally, nationally, and globally into a seamless net of causes and effects. (...) Sustainable development requires meeting the basic needs of all and extending to all the opportunity to fulfil their aspirations for a better life. A world in which poverty is endemic will always be prone to ecological and other catastrophes. (...) Hence, our inability to promote the common interest in sustainable development i soften a product of the relative neglect of economic and social justice within and amongst nations" (WCED 1987: 5. 8. 49). In 1988 the Centre for Our Common Future was established in order to spread the ideas of the Brundtland Report and of sustainability.

The sustainability discourse seems to signify a shift in consciousness and worldview that gives a high priority to human responsibility. Andrés R. Edwards (2005) argues that like the industrial revolution the "Sustainability Revolution" constitutes a major shift of societal paradigms. "The Sustainability Revolution is affecting the economic, ecological and social aspects of societies worldwide. (...) Sustainability is in fact a revolution with a new value system, consciousness and worldview. (...) The Sustainability Revolution evolved as a reaction to the Industrial Revolution's degradation of the environment and our well-being. The rampant environmental impacts and the recognition of te limits of natural resources combined to produce a new methods embodied in the sustainability Revolution" (Edwards 2005: 2. 5). However, the question is not only if there is a new worldview, but if the sustainability- worldview can be accompanied by material and social changes that constitute the transition towards a sustainable society. Sustainability is not mainly a spiritual issue, but a material one.

In 1992 the UN Conference on Environment and Development ("Earth Summit") took place in Rio de Janeiro, Brazil, where for the first time heads of state from all over the world gathered to discuss problems of sustainability. At the Earth Summit all participating countries agreed to the Rio Declaration on Environment and Development that put forward 27 principles for the future that can help in achieving sustainable development. The Declaration starts with the principle that "human beings are at the centre of concerns for sustainable development. They are entitled to a healthy and productive life in harmony with nature". It covers a wide range of issues such as the environment, poverty, demography, the economy, gender, youth, indigenous people, peace and shows that sustainability is an integrative concept that stresses the interdependence of all realms of society. The Rio Declaration made clear that we could no longer think of environment and economic and social development as isolated fields. The Agenda 21 document is the action plan implemented for achieving the goals of the Rio Declaration. It strives to reconcile the two requirements of a high quality environment and a healthy economy for all people of the world. All national governments represented at the Earth Summit committed themselves to the principles of action contained in the Agenda 21 document. At the Earth Summit the participants also agreed to the formation of the UN Commission on Sustainable Development as an international environmental organization that monitors the progress towards achieving the objectives of Agenda 21. Outcomes of the Earth Summit were the Statement of Principles on the Management, Conservation and Sustainable Development of All Types of Forests, the UN Framework Convention on Climate Change, the UN Convention on Biological Diversity, and a recommendation for an international convention on desertification.

An important instrument in international co-operation for achieving sustainable development are international treaties such as the Convention on International Trade in Endangered Species of Flora and Fauna (1973), the Montreal Protocol on Substances That Deplete the Ozone Layer (1987), the UN 
Framework Convention on Climate Change signed by more than 150 states at the Earth Summit in Rio (1992), the Convention on Biological Diversity (1992), United Nations Convention to Combat Desertification (1994), United Nations Convention to Combat Desertification (1994), United Nations Convention on the Law of the Sea (1994), the International Tropical Timber Agreement (1994), the Kyoto Protocol to the United Nations Framework Convention on Climate Change (1997), and many more.

The discourse on sustainable development shows a shift from the view of nature as an enemy that must be controlled to a view that considers nature as an important pre-condition of human existence that must be treated carefully. Following the Earth Summit the EU's "Towards Sustainability" (1993) has stressed that economic and social development should be linked to the improvement of the environment. In 2001 the EU has presented its plan for reaching a sustainable Europe ("A Sustainable Europe for a Better World: A European Union Strategy for Sustainable Development"). The latter identifies threats to sustainable development and suggests actions for reaching a sustainable Europe. The strategic goal of the European Union for 2010 that has been set at the Lisbon European Council in March 2000 is to "become the most competitive and dynamic knowledge-based economy in the world, capable of sustainable economic growth with more and better jobs and greater social cohesion". The European Union Strategy for Sustainable Development argues that in order to reach this goal "in the long term, economic growth, social cohesion and environmental protection must go hand in hand".

Following the Earth Summit, US-President Bill Clinton in 1993 established the President's Council on Sustainable Development (PCSD) providing a domestic agenda for sustainable development. In 1999 the Council completed its third and final report "Towards a Sustainable America: Advancing Prosperity, Opportunity, and a Healthy Environment fort he 21st Century" that recommends 140 actions aimed to "improve our economy, protect our environment, and improve our quality of life. Many of these actions address important current issues like sprawl, climate change, urban renewal, and corporate environmental responsibility" (President's Council on Sustainable Development 1999).

In 2002 the World Summit on Sustainable Development (WSSD) conference was held in Johannesburg with the intention of having a review ten years after the 1992 Rio Earth Summit. The outcomes include a Plan of Implementation and the Johannesburg Declaration on Sustainable Development. The Plan of Implementation designed a means for acting on the topics discussed at the Earth Summit such as poverty eradication, production and consumption issues and health concerns. The Johannesburg Declaration comprises 36 principles and emphasizes the current issues facing the world community and the significance of multilateralism and practical implementation strategies. Whereas the Earth Summit focused on the environmental issues of sustainability, the WSSD conference more effectively integrated economic and equity issues into the discussion. The Johannesburg Declaration identifies a number of challenges that humanity faces in creating a sustainable world:

"11. We recognize that poverty eradication, changing consumption and production patterns and protecting and managing the natural resource base for economic and social development are overarching objectives of and essential requirements for sustainable development. 12. The deep fault line that divides human society between the rich and the poor and the ever-increasing gap between the developed and developing worlds pose a major threat to global prosperity, security and stability.

13. The global environment continues to suffer. Loss of biodiversity continues, fish stocks continue to be depleted, desertification claims more and more fertile land, the adverse effects of climate change are already evident, natural disasters are more frequent and more devastating, and developing countries more vulnerable, and air, water and marine pollution continue to rob millions of a decent life. 14. Globalization has added a new dimension to these challenges. The rapid integration of markets, mobility of capital and significant increases in investment flows around the world have opened new challenges and opportunities for the pursuit of sustainable development. But the benefits and costs of 
globalization are unevenly distributed, with developing countries facing special difficulties in meeting this challenge".

The Declaration argues that decisions are needed to "to speedily increase access to such basic requirements as clean water, sanitation, adequate shelter, energy, health care, food security and the protection of biodiversity. At the same time, we will work together to help one another gain access to financial resources, benefit from the opening of markets, ensure capacity-building, use modern technology to bring about development and make sure that there is technology transfer, human resource development, education and training to banish underdevelopment forever" (Principle 18). It reaffirms the pledge to "place particular focus on, and give priority attention to, the fight against the worldwide conditions that pose severe threats to the sustainable development of our people, which include: chronic hunger; malnutrition; foreign occupation; armed conflict; illicit drug problems; organized crime; corruption; natural disasters; illicit arms trafficking; trafficking in persons; terrorism; intolerance and incitement to racial, ethnic, religious and other hatreds; xenophobia; and endemic, communicable and chronic diseases, in particular HIVIAIDS, malaria and tuberculosis“" (Principle 19).

In the discourse on sustainability there has been a shift from a focus on ecological issues towards the inclusion of broader societal issues. The "triangle of sustainability" introduced by the World Bank has been very important in shifting discussion on sustainability from purely ecological aspects towards more integrative concepts. Ismail Serageldin, then vice-president of the World Bank, identified an economic, a social, and an ecological dimension of sustainability. "It is not surprising that these concerns reflect the three sides of what I have called the "triangle of sustainability"-its economic, social, and ecological dimensions" (Serageldin 1995: 17). It has now become very common to identify an ecological, an economic, a social, and an institutional dimension of sustainability (as e.g. the EU and the UN do). "At the time of Rio, sustainable development was mainly about protecting nature, but now, in the wake of Johannesburg, it is first and foremost about protecting people. For nobody can close his or her eyes in front of what can be called the 21st century challenge, namely how best to extend hospitality to twice the number of people on the globe, in light of a rapidly deteriorating biosphere? Indeed, the historical pattern of scarcity, which had left its imprint to economic development and continues to shape it, today is outdated. While in the old days the world appeared full of nature, but void of people, today the world is void of nature, but full of people. The satisfaction of needs and wants is not constrained so much by the paucity of hands and brains, but by the scarcity of resources and living systems. Nature is now more of a limiting factor than money, given that development is more and more restricted not by the number of fishing boats, but by the decreasing numbers of fish; not by the power of pumps, but by the depletion of aquifers; not by the number of chainsaws but by the disappearance of primary forests. (World Summit on Sustainable Development 2002a: 22).

Frequently economic interests are detrimental to achieving ecological and social sustainability. Greenpeace concludes in a study on corporate crime that "these cases illustrate that irresponsible corporate behaviour continues to severely affect both the environment and people's health, and that the companies who are responsible fail to respond in an adequate manner. They show how companies routinely fail to compensate and/or assist impacted communities, how they evade obligations to clean up or remediate damaged environments, and, by and large, violate human and community rights by failing to monitor, report and provide essential information concerning their products and processes. Such behaviour is no less than criminal, and it is becoming increasingly difficult-sometimes impossible--to seek justice, and to hold these companies accountable and liable for their crimes" (Greenpeace 2002: 7). Therefore Greenpeace demands the extension of corporate liability: "Corporations must be held strictly liable without requirement of fault for any and all damage arising from any of their activities that cause environmental or property damage or personal injury, including site remediation. Parent companies as well as subsidiaries and affiliated local corporations must be held liable for compensation and restitution. 
Corporations must bear cradle to grave responsibility for manufactured products. States must implement individual liability for directors and officers for actions or omissions of the corporation, including for those of subsidiaries" (Greenpeace 2002: 4) .

\section{2. A Typology of Approaches on Sustainability}

In the relationship of nature and society human beings and groups act as subjects that appropriate and change nature in different ways. Although nature is active itself (it produces itself permanently in autopoietic cycles), it is an objective structure in society that is changed by man and enables the latter's activity. Hence one can conceive human individuals and groups as subjects and natural resources as objects in the nature-society-relationship. One can distinguish four types of sustainability concepts based on where in the nature-society-relationship they locate sustainability. Ecological reductionistic approaches define sustainability primarily in ecological terms, social projectionism considers sustainability as a quality of social systems, dualistic approaches speak of both a sustainable ecology and a sustainable society, but they consider both realms to be independent. Ecological reductionism ignores social aspects of sustainability such as wealth, participation, and wisdom, social projectionism is ignorant of the relative autonomy of nature, dualistic approaches ignore the interconnectedness and interdependence of nature and society. Dialectical approaches on sustainability try to solve the problems of these concepts by arguing that societal sustainability requires ecological sustainability and ecological sustainability societal sustainability, the two systems mutually enhance each other.

\begin{tabular}{|l|l|l|}
\hline \multicolumn{1}{|c|}{ Approach } & \multicolumn{1}{|c|}{ Nature (Object) } & \multicolumn{1}{c|}{ Society (Subject) } \\
\hline Ecological Reductionism & $\begin{array}{l}\text { Sustainability of } \\
\text { Ecology }\end{array}$ & \\
\hline Social Projectionism & & Sustainability of Society \\
\hline Dualism & $\begin{array}{l}\text { Sustainability of } \\
\text { Ecology }\end{array}$ & Sustainability of Society \\
\hline Dialectic Thinking & Interconnected Sustainability of Ecology and Society \\
\hline
\end{tabular}

Tab. 1: A Typology of Approaches on Sustainability

Both nature and society are self-organizing systems in the sense that they permanently produce themselves, i.e. their elements and unity, they are self-maintaining, self-reproducing, and (in the case of society) self-reflecting. Nature is made up of eco-systems that permanently reproduce themselves, they are living, autopoietic systems that permanently reproduce their elements and their unity. If man negatively influences nature by depleting and polluting natural resources, ecosystems are no longer able to autopoietically reproduce themselves and break down. Hence their processes of reproduction and differentiation come to a halt. Ecological sustainability means that humans appropriate nature in a way that allows ecological diversity, i.e. the autopoiesis of nature can develop in such a way that nature flourishes, reproduces its subsystems, differentiates itself and produces new qualities, i.e. new ecological life forms and subsystems.

Social systems and society are self-organizing in the sense that there is a permanent mutual production of social structures and practices of human actors. These processes are goal-oriented, i.e. humans have the ability to identify and anticipate different paths of development, to judge which ones they consider as desirable and to act according to these wishes, values, and desires. Societal sustainability is based on the desire of all human beings to live in a fair, just, and beautiful society. All humans want to live a good life, if one desires to have a good life for oneself, one must also recognize that all humans have the right to live such a life and hence societal sustainability can broadly be defined as a good life for all. Society is made up of different, interconnected subsystems: ecology, technology, economy, polity, and culture. Sustainability is a desirable aspect that humans strive for in all of these subsystems. A sustainable society encompasses ecological diversity, technological usability, economic wealth, political participation, and 
cultural wisdom. Usability means that technologies are designed in a user-friendly way and support humans in achieving their goals more easily. Economic wealth means that basic needs and social security should be provided for all human beings. Political participation requires a distribution of power that enables humans to adequately influence those decisions that affect them. A culturally wise society is one that is critical, self-reflective, allows a plurality of life-styles, meanings, ways of life, and values that complement each other (unity in diversity) and finds ways to solve and manage its problems in a way that brings advantages for all. Culture is made up by various subsystems such as the mass media, science, art, education, ethics/belief systems, medicine, sports, and the system of social relationships. In these systems cultural sustainability, i.e. wisdom, has different meanings such as wise knowledge and media (mass media), truth (science), beauty and imagination (art), literacy and good skills (education), openness and unity in diversity of values and rights (ethics), health (medicine), fitness (sports), love and understanding (social relationships).

In a dialectical approach on sustainability ecological sustainability is based on social sustainability and vice versa, i.e. biological diversity is best advanced by a society where we finds technological usability, economic wealth for all (i.e. a rather symmetrical distribution of wealth), political participation for all, and cultural wisdom and a biological rich and diverse ecosystem is a life-support system that is a good foundation for a socially sustainable society where one finds social systems that are usable, wealthy, participatory, and wise. An unsustainable ecosystem advances an unsustainable society and vice versa: If man pollutes nature and depletes non-renewable natural resources problems, i.e. if he creates an unhealthy environment, problems such as poverty, war, totalitarianism, extremism, violence, crime, etc. are more likely to occur. The other way round a society that is shaken by poverty, war, a lack of democracy and plurality, etc. is more likely to pollute and deplete nature. This can result in a vicious cycle where nature and society are connected in negative feedback loops that have destructive effects for both systems. If nature and society are connected in sustainable ways there can be positive feedback loops that enable both systems to flourish and to develop in sustainable ways. Sustainable development of the ecosystem means that it increases its diversity and reproduces itself, sustainable development of the sociosphere means that it increases wealth for all, fosters technological progress that benefits all, and enhances participation and wisdom for all. In a sustainable society social structures such as technology, property/use values, power, and knowledge/meaning are produced and enhanced in ways that benefit all human beings, the self-organization cycles of a sustainable society develop in such a way that a good life for all is possible, the self-organization of the ecosystem and the self-organization of the socio-sphere positively influence each other.

\begin{tabular}{|l|l|}
\hline Dimension & Quality \\
\hline Ecological Sustainability & Biological Diversity \\
\hline Technological Sustainability & Usability \\
\hline Economic Sustainability & Wealth for All \\
\hline Political Sustainability & Participation of All \\
\hline Cultural Sustainability & Wisdom \\
Sustainability of: & \\
& \\
Mass Media & Wise Knowledge and Media \\
Science & Truth \\
Art & Beauty and Imagination \\
Education & Literacy and Good Skills \\
Morals & Openness, Unity in Diversity of Values and \\
& Rights \\
Medicine & Health \\
Sports & Fitness \\
\hline
\end{tabular}




\begin{tabular}{|l|l|}
\hline Social Relationships & Love and Understanding \\
\hline
\end{tabular}

Tab. 2: Dimensions of Sustainability

I will now discuss examples for the different approaches on sustainability.

\section{III.2.1. Objective Approaches: Ecological Reductionism}

Concepts and definitions that belong to this type of approach are aware of ecological aspects of sustainability, but as the following definitions show they lack the awareness of societal, i.e. technological, economic, political, and cultural aspects of sustainability.

"Sustainable development - to be the indefinite survival of the human species (with a quality of life beyond mere biological survival) through the maintenance of basic life support systems (air, water, land, biota) and the existence of infrastructures and institutions which distribute and protect the components of these systems" (Brown et al. 1988). The focus here is on natural resources.

Sustainable development means "improving the quality of human life while living within the carrying capacity of supporting ecosystems. [...] Sustainable development - maintenance of essential ecological processes and life support systems, the preservation of genetic diversity, and the sustainable utilization of species and ecosystems" (IUCN/WWF/UNEP 1980: 210, 227). This definition stresses aspects of the ecosystem.

"If we now apply the idea to resources, sustainability ought to mean that a given stock of resources trees, soil quality, water, and so on - should not decline" (Markandya/Pearce 1988). Here the focus is on natural resources.

"Ecologically sustainable development is a condition in which society's use of renewable resources takes place without destruction of the resources or the environmental context which they require" (Solomon 1990).

"Maintenance of a steady state is one of the operational definitions of sustainable development. A steady state is a dynamic state in which changes tend to cancel each other out (...) Maintenance of a steady state in terms of resources, species and pollution would imply the following:

- $\quad$ use of (conditionally) renewable resources should, within a specific area and time span, not exceed the formation of new stocks. Thus, for instance, yearly extraction of groundwater should not exceed the yearly addition to groundwater reserves coming from rain and surface water;

- $\quad$ use of relatively rare nonrenewable resources, such as fossil carbon or rare metals, should be close to zero, unless future generations are compensated for current use by making available for future use an equivalent amount of renewable resources" (Opschoor/Reijnders 1991).

The last two definitions stress non-renewable natural resources.

"Biogeophysical sustainability is the maintenance and/or improvement of the integrity of the life-support system on Earth. Sustaining the biosphere with adequate provisions for maximizing future options includes providing for human economic and social improvement for current and future human generations within a framework of cultural diversity while: (a) making adequate provisions for the maintenance of biological diversity and (b) maintaining the biogeochemical integrity of the biosphere by conservation and proper use of its air, water and land resources. Achieving these goals requires planning and action at local, regional and global scales and specifying short- and long-term objectives that allow for the transition to sustainability" (Munasinghe/Shearer 1995). This concept stresses biological diversity and conservation of nature. 
"Sustainability is whether (not the extent to which) the productive potential of a certain natural system will continue (for a long time, at least several decades) under a particular management practice (intensity and type of technical and social activities, e.g. inputs of energy, nutrients, genetic variety, harvesting procedures, and cyclic variations over time)" (Carpenter 1995). Here the focus is on the natural system.

"We fundamentally depend on natural systems and resources for our existence and development. Our efforts to defeat poverty and pursue sustainable development will be in vain if environmental degradation and natural resource depletion continue unabated. At the country level, national strategies must include investments in improved environmental management and make the structural changes required for environmental sustainability. For many environmental priorities, such as shared waterways, forests, marine fisheries and biodiversity, regional and global efforts must be strengthened" (Annan 2005: 19) The three main problems of unsustainable development would be desertification, loss of biodiversity, and climate change. Hence this concept stresses ecological aspects.

"Prudence must be shown in the management of all living species and natural resources, in accordance with the precepts of sustainable development. Only in this way can the immeasurable riches provided to us by nature be preserved and passed on to our descendants. The current unsustainable patterns of production and consumption must be changed in the interest of our future welfare and that of our descendants" (United Nations 2000: 5). Here the focus is on the preservation of nature.

"But our natural world is under severe threat. For decades we've been over-exploiting the land and oceans, and we've pumped so much pollution into the air that we're actually changing the weather. The root cause of our environmental problems - a skewed approach to economics, and business that puts profits first - is also deepening inequalities. Across the world it's the people with least power and money who are worst hit when the environment is damaged - and they're not getting their fair share of the benefits. [...] We should all have a healthy environment. Healthy homes, streets, neighbourhoods, villages, cities and wild places. But not at someone else's expense" (Friends of the Earth: 2, 4). This concept stresses the importance of a healthy environment.

\section{2.2. Subjective Approaches: Social Projectionism}

Concepts of this type of approach on sustainability stress one or several aspects of society that are considered as being important for achieving sustainable development. Generally speaking not only do many of these definitions leave out the interconnection of ecological and societal issues, they also reduce societal sustainability to single aspects and lack a plural concept that integrates technological, economic, political, and cultural aspects of society.

"Sustainable development is development that meets the needs of the present without compromising the ability of future generations to meet their own needs. Sustainable development is not a fixed state of harmony, but rather a process of change in which the exploitation of resources, the direction of investments, the orientation of technological development and institutional changes are made consistent with future as well as present needs" (WCED 1987: 43). This (probably most well-known) definition of sustainability by the World Commission on Environment and Development is very general and focuses on social practices that guarantee the survival of future generations.

By using the notion of glacial time developed by Scott Lash and John Urry Manuel Castells (2004) advances an idea of sustainability that comes close to the one of the WCED: "The idea of limiting the use of resources to renewable resources, central to environmentalists, is predicated precisely on the notion that alteration of basic balances in the planet, and in the universe, may, over time, undo a delicate ecological equilibrium, with catastrophic consequences. (...) In any direct, personal terms, glacial time 
means to measure our life by the life of our children and of the children of our children. (...) To propose sustainable development as intergenerational solidarity brings together healthy selfishness and systemic thinking in an evolutionary perspective" (Castells 2004: 183f). Castells considers sustainability as a generational issue and as one of the evolution of society.

"Sustainable development involves devising a social and economic system, which ensures that these goals are sustained, i.e. that real incomes rise, that educational standards increase, that the health of the nation improves, that the general quality of life is advanced" (Pearce et al. 1989). This definition focuses on income, education, health, and social issues.

"Sustainable development - development that is likely to achieve lasting satisfaction of human needs and improvement of the quality of human life" (Allen 1980). Here sustainability is connected in very general terms to the quality of human life.

"The concept of sustainable economic development as applied to the Third World (...) is therefore directly concerned with increasing the material standard of living of the poor at the "grassroots" level, which can be quantitatively measured in terms of increased food, real income, educational services, health care, sanitation and water supply, emergency stocks of food and cash, etc., and only indirectly concerned with economic growth at the aggregate, commonly national, level. In general terms, the primary objective is reducing the absolute poverty of the world's poor through providing lasting and secure livelihoods that minimize resource depletion, environmental degradation, cultural disruption and social instability" (Baribier 1987). This definition focuses primarily on economic standards of living.

"Sustainable development is here defined as a pattern of social and structured economic transformations (i.e. development) which optimizes the economic and societal benefits available in the present, without jeopardizing the likely potential for similar benefits in the future. A primary goal of sustainable development is to achieve a reasonable (however defined) and equitably distributed level of economic well-being that can be perpetuated continually for many human generations" (Goodland/Ledoc 1987). Here the focus is on the distribution of economic resources.

"Sustainable development - economic development that can continue indefinitely because it is based on the exploitation of renewable resources and causes insufficient environmental damage for this to pose an eventual limit" (Allaby 1988). This definition stresses economic development.

"Sustainable development is the maintenance or growth of the aggregate level of economic well-being, defined as the level of per capita economic well-being" (Haveman 1989). Here sustainability is understood in purely economic terms.

"[Sustainable development] is usually applied to less developed countries and the kind of economic and social development needed to improve the living conditions of the world's poor without destroying or undermining the natural resource base" (McCormick 1991). This concept stresses poverty reduction.

"Sustainable development: The amount of consumption that can be sustained indefinitely without degrading capital stocks, including natural capital stocks" (Costanza/Wainger 1991). The focus here is on economic consumption.

"Sustainable development may be defined as the development and management of natural resources to ensure or enhance the long-term productive capacity of the resource base and improve the long-term wealth and well-being derived from alternative resource use systems, with acceptable environmental impacts" (Schultink 1992). This definition stresses social and economic aspects of sustainability. 
"[Sustainable development] is concerned with (a) the rights of future generations to the services of natural and produced assets and (b) whether the formal and informal institutions which affect the transfer of assets to future generations are adequate to assure the quality of life in the long-run" (Norgaard 1992). The focus here is on economic and natural resources.

"Sustainable development is a complex of activities that can be expected to improve the human condition in such a manner that the improvement can be maintained" (Munro 1995). Sustainability here refers in very general terms to human conditions.

"Human beings are at the centre of concerns for sustainable development. They are entitled to a healthy and productive life in harmony with nature. People are the most important and valuable resource of any nation. Countries should ensure that all individuals are given the opportunity to make the most of their potential. They have the right to an adequate standard of living for themselves and their families, including adequate food, clothing, housing, water and sanitation. [...] Sustainable development as a means to ensure human well-being, equitably shared by all people today and in the future, requires that the interrelationships between population, resources, the environment and development should be fully recognized, properly managed and brought into harmonious, dynamic balance. To achieve sustainable development and a higher quality of life for all people, States should reduce and eliminate unsustainable patterns of production and consumption and promote appropriate policies, including population-related policies, in order to meet the needs of current generations without compromising the ability of future generations to meet their own needs" (International Conference on Population and Development 2004: Principles 2+6, 8-10). The focus here is on basic resources such as food, clothes, houses, water, etc.

"A process of achieving human development in an inclusive, connected, equitable, prudent, and secure manner. Inclusiveness implies human development over time and space. Connectivity entails an embrace of ecological, social, and economic interdependence. Equity suggests intergenerational, intergeneration, and interspecies fairness. Prudence connotes duties of care and prevention: technologically, scientifically, and politically. Security demands safety from chronic threats and protection from harmful disruption" (Gladwin/Kennelly/Krause 1995). This concept stresses economic, technological, scientific, and political aspects of sustainability.

\section{2.3. Dualistic Approaches}

The following definitions show that there is a type of approach that acknowledges both ecological and societal aspects of sustainability, but doesn't see that the two aspects are interrelated.

"Our vision is of a life-sustaining Earth. We are committed to the achievement of a dignified, peaceful, and equitable existence. A sustainable United States will have a growing economy that provides equitable opportunities for satisfying livelihoods and a safe, healthy, high quality of life for current and future generations. Our nation will protect its environment, its natural resource base, and the functions and viability of natural systems on which all life depends. [...] To achieve our vision of sustainable development, some things must grow - jobs, productivity, wages, capital and savings, profits, information, knowledge, and education and others - pollution, waste, and poverty - must not" (President's Council on Sustainable Development 1999: ivf). In this concept one simply finds goals such as an efficient economy and a save environment, but there are no arguments on how nature and society are connected and if and how these goals can be achieved.

"Sustainability is the ability to achieve economic prosperity while protecting the natural systems of the planet, and providing a higher quality of life for its people" (US Environmental Protection Agency, 
http://www.epa.gov/sustainability/). Also in this definition economic prosperity and ecological diversity are proclaimed, but are seen as separate topics.

"Humanity stands at a defining moment in history. We are confronted with a perpetuation of disparities between and within nations, a worsening of poverty, hunger, ill health and illiteracy, and the continuing deterioration of the ecosystems on which we depend for our well-being. However, integration of environment and development concerns and greater attention to them will lead to the fulfilment of basic needs, improved living standards for all, better protected and managed ecosystems and a safer, more prosperous future. No nation can achieve this on its own; but together we can - in a global partnership for sustainable development" (United Nations Conference on Environment \& Development 1992a: 3). Here we find the proclamation of ecological and societal goals, but there is no indication on how these goals are connected. Also in the following two definitions by the UN both societal and ecological aspects are mentioned, but not connected.

"Human beings are at the centre of concerns for sustainable development. They are entitled to a healthy and productive life in harmony with nature. [...] The right to development must be fulfilled so as to equitably meet developmental and environmental needs of present and future generations. [...] In order to achieve sustainable development, environmental protection shall constitute an integral part of the development process and cannot be considered in isolation from it. [...] All States and all people shall cooperate in the essential task of eradicating poverty as an indispensable requirement for sustainable development, in order to decrease the disparities in standards of living and better meet the needs of the majority of the people of the world. [...] To achieve sustainable development and a higher quality of life for all people, States should reduce and eliminate unsustainable patterns of production and consumption and promote appropriate demographic policies" (United Nations Conference on Environment \& Development 1992b: Principles 1, 4, 5, 8).

"Sustainable development means that economic activities should only be extended as far as the level of maintenance of man-made and natural capital will permit. A narrower definition of sustainability excludes the substitution between natural and man-made assets and requires maintenance of the level of natural assets as well as man-made assets. A sustainable development seems to necessitate especially a sufficient water supply, a sufficient level of land quality (prevention of soil erosion), protection of existing ecosystems (e.g. the virgin tropical forests) and maintaining air and water quality (prevention of degradation by residuals). In these cases, the sustainability concept should not only imply constancy of the natural assets as a whole (with some possibility of substitution) but constancy of each type of natural asses (e.g. of the specific ecosystems)" (United Nations Statistical Office 1992). The focus here is on both human and natural assets, but both realms are treated separately.

"In broad terms the concept of sustainable development encompasses: 1. Help for the very poor because they are left with no option other than to destroy their environment;

2. The idea of self-reliant development, within natural resource constraints;

3. The idea of cost-effective development using differing economic criteria to the traditional approach; that is to say development should not degrade environmental quality, nor should it reduce productivity in the long run;

4. The great issues of health control, appropriate technologies, food self-reliance, clean water and shelter for all;

5. The notion that people-centered initiatives are needed; human beings, in other words, are the resources in the concept" (Tolba 1987).

This concept consists of a list of ecological and societal aspects of sustainability, interconnections are missing. 
"Sustainable development - improving the quality of human life while living within the carrying capacity of supporting ecosystems" (IUCN/WWF/UNEP 1991). Here both human life conditions and ecosystems are mentioned.

"Sustainable development means basing developmental and environmental policies on a comparison of costs and benefits and on careful economic analysis that will strengthen environmental protection and lead to rising and sustainable levels of welfare" (World Bank 1992). Environmental protection and welfare are treated here as two separate topics.

"A sustainable society is one that can persist over generations, one that is far-seeing enough, flexible enough, and wise enough not to undermine either its physical or its social systems of support" (Meadows et al. 1992). Both physical and social aspects are mentioned here, but it remains unclear how they are connected.

"Sustainable development should be a process which allows for the satisfaction of human necessities without compromising the basis of that development, which is to say, the environment" (Winograd 1995). Human necessities and the environment are both considered as important, but again there is no indication on how they are related to each other.

"A sustainable society implicitly connotes one that is based on a long-term vision in that it must foresee the consequences of its diverse activities to ensure that they do not break the cycles of renewal; it has to be a society of conservation and generational concern. It must avoid the adoption of mutually irreconcilable objectives. Equally, it must be a society of social justice because great disparities of wealth or privilege will breed destructive disharmony" (Hossain 1995). Social justice and conservation are considered as important here, but both ecological and social issues are treated separately.

"Ensure environmental sustainability: Amongst other things, the loss of environmental resources should be reversed, the number of people without access to safe drinking water (more than one billion today) halved by 2015, and by 2020 the living conditions of more than 100 million people living in slums significantly improved" (Global Marshall Plan Initiative 2004: 93). This is a very unclear concept of sustainability, there is no definition, the authors speak of environmental sustainability, but also mention social goals.

\section{2.4. Dialectical Approaches}

Such concepts acknowledge that there are both societal and ecological aspects of sustainability and that ecological sustainability is a foundation of societal sustainability and vice versa.

"At the core of the Brown Agenda are the dirty air risks of resource depletion and the need for and water in cities, which can make people sick in just a few hours, and which, together with issues on the Green Agenda, pose severe cross- generational risks. The short-term urgency of this agenda adds to the moral urgency of reducing poverty and developing the world's poorest communities. Indeed, it is the intersection of these three concerns-reducing poverty, protecting the environment, and improving the productivity of urban economic activities-that is the objective of our urban policy. It is not surprising that these concerns reflect the three sides of what I have called the "triangle of sustainability"-its economic, social, and ecological dimensions" (Serageldin 1995: 17). Serageldin identifies economic, social, and ecological dimensions of sustainability. This "triangle of sustainability" introduced by the World Bank has been very important in shifting discussion on sustainability from purely ecological aspects towards more integrative concepts. "Natural and human-made environmental resources - fresh water, clean air, forests, grasslands, marine resources, and agroecosystems - provide sustenance to people and are the 
foundation for social and economic development. [...] Our Environment Strategy focuses on forging links among environment, poverty, and development, with particular emphasis on the health, livelihoods, and vulnerability of poor people“" (World Bank 2005a: 52f).

"Sustainable development is development that meets the needs of people today without compromising those of future generations. It is about living within our means, valuing nature's services and ensuring development potential for those who follow us. Sustainable development means balancing economic needs with environmental and social needs - a tripartite alliance. The conservation of nature and natural processes is not an optional extra; rather, it is the foundation of human welfare because of the vital ecosystem services they provide, such as the provision of water, food and medicines" (World Wide Fund for Nature, WWF, http://www.wwf.org.uk/researcher/issues/internationaldevelopment/). This definition sees that ecological sustainability is a foundation of societal sustainability, but it leaves out that societal sustainability is also a foundation of ecological sustainability.

"The social fabric and the natural environment around us are as fundamental to our quality of life, and to that of future generations, as our economic performance. This vision of balanced and responsible progress in social, economic and environmental spheres is precisely what is captured by the idea of 'sustainable development"' (European Commission 2002: 3). "Nevertheless, there is a broad consensus that, at a minimum, sustainable development captures two important ideas: - That development has an economic, a social and an environmental dimension. Development will only be sustainable if a balance is struck between the different factors that contribute to the overall quality of life. - That the current generation has an obligation to future generations to leave sufficient stocks of social, environmental and economic resources for them to enjoy levels of well being at least as high as our own" (European Commission 2001: 10f).

This concept sees that there are social, economic, and environmental aspects of sustainability and it argues that a balanced interconnection should be achieved. There seems to be some type of interconnection between ecological and societal sustainability, but the balance that should be achieved is not defined in more detail.

"To avoid this impasse, it is important to promote sustainable livelihoods. Sustainable in both senses of the word: firstly, an activity that provides a decent income or sustenance and provides some status in society along with a meaningful life; and secondly, an activity which conserves and, if possible, regenerates the environment. Productive ecosystems are core assets for sustainable livelihoods, since grasslands, forests, fields, and rivers can be valuable sources of sustenance. This is the main reason why livelihood-centred strategies of poverty removal coincide with the interest in environmental protection. Ecology is thus essential for ensuring decent livelihoods in society. Securing community rights to natural resources is therefore a hallmark of livelihood politics. However, strengthening the rights of local communities means weakening the claims of distant income earners and consumers. Thus the direct or indirect demand of the corporate-driven middle classes for easily available and cheap resources will have to be checked since the interest of middle classes in expanding consumption and of corporations in profit expansion often collides with the interest of communities in securing their livelihoods. These resource conflicts will not be eased unless the economically well-off on the globe make the transition towards resource-light patterns of production and consumption" (World Summit on Sustainable Development 2002a: 22). The Summit here stresses that a healthy environment is the foundation of a sustainable society, societal and environmental issues are connected. It has acknowledged that there are three "interdependent and mutually reinforcing pillars of sustainable development - economic development, social development and environmental protection" (World Summit on Sustainable Development 2002b: 1). Economic growth, ecological balance and social progress are considered as interconnected issues.

"Sustainable economy: A sustainable economy is one which operates within environmental limits, generates employment and increases quality of life for all. At present our economy is threatening 
environmental limits, producing jobless growth and reducing quality of life. This situation has to be reversed. [...] Social sustainability: Inequality and exclusion undermine sustainability. If we fail to restore or create social justice in our communities in the UK then our efforts to make economic and environmental progress will be undermined by the costs of inequality (Chapter 11). Inequality worsens health, hampers economic performance and destroys social cohesion. [...] Investing in the public good of eliminating poverty rather than perpetuating it, as happens at present, is central to sustainability. Not only does this benefit the poor themselves but, as inequality is reduced and social cohesion is rebuilt, the whole of society gains. [...] Political sustainability: [...] Small groups of very powerful vested interests, representing a tiny minority of people, have a grossly disproportionate amount of influence over Governments. [...] We need, as a matter of urgency, to reverse the accelerating trend to remove decision-making away from the people who are affected by it. Sustainability in the UK demands a renewal of democracy that puts citizen rights and responsibilities at the heart of politics. But if we are to have a sustainable society, a stakeholder society even, then there needs to be far-reaching reforms that establish rights and ensure accountability" (Friends of the Earth 1998, Summary). This concepts connects environmental and ecological aspects, it argues that social sustainability (social justice) is needed for economic and environmental progress, and that there are political and democratic aspects of sustainability. What is missing is the insight that ecological sustainability is a foundation of social sustainability.

\section{Measuring the Sustainability of the Information Society}

\section{IV.1. Measuring the Information Society}

The discourse on the information and knowledge society has from its beginning been accompanied by questions of how to define and measure this transition of society. In sociological theories there are different definitions of and indicators for the existence of an information society. Fritz Machlup (1962) has introduced the concept of the knowledge industry. He has distinguished five sectors of the knowledge sector: education, research and development, mass media, information technologies, information services. Based on this categorization he calculated that in 1959 29\% per cent of the GNP in the USA had been produced in knowledge industries. Peter Drucker (1969) has argued that there is a transition from an economy based on material goods to one based on knowledge. Marc Porat (1977) distinguishes a primary (information goods and services that are directly used in the production, distribution or processing of information) and a secondary sector (information services produced for internal consumption by government and non-information firms) of the information economy. Porrat uses the total value added by the primary and secondary information sector to the GNP as an indicator for the information economy. The OECD has employed Porat's definition for calculating the share of the information economy in the total economy (e.g. OECD 1981, 1986). Based on such indicators the information society has been defined as a society where more than half of the GNP is produced and more than half of the employees are active in the information economy (Deutsch 1983).

For Daniel Bell the number of employees producing services and information is an indicator for the informational character of a society. "A post industrial society is one in which the majority of those employed are not involved in the production of tangible goods" (Bell 1976: 348). Similarly to Bell Peter Otto and Philipp Sonntag (1985) say that an information society is a society where the majority of employees work in information jobs, i.e. they have to deal more with information, signals, symbols, and images than with energy and matter. Radovan Richta (1977) argues that society has been transformed into a scientific civilization based on services, education, and creative activities. This transformation would be the result of a scientific-technological transformation based on technological progress and the increasing importance of computer technology. Science and technology would become immediate forces of production. 
Nico Stehr $(1994,2002)$ says that in the knowledge society a majority of jobs involves working with knowledge. "Economic capital - or, more precisely, the source of economic growth and value-adding activities - increasingly relies on knowledge. The transformation of the structures of the modern economy by knowledge as a productive force constitutes the 'material' basis and justification for designating advanced modern society as a 'knowledge society'. The significance of knowledge grows in all spheres of life and in all social institutions of modern society. [...] One can define knowledge as 'the capacity to act', as the potential to 'start something going'. [...] Thus scientific or technical knowledge is primarily nothing other than the ability to act. [...] What is new is the large number of professions that involve working with knowledge. At the same time the number of jobs that demand low cognitive skills is rapidly declining, resulting in less and less people being involved in the manufacture and distribution of material goods" (Stehr 2002). Also Alvin Toffler argues that knowledge is the central resource in the economy of the information society: "In a Third Wave economy, the central resource - a single word broadly encompassing data, information, images, symbols, culture, ideology, and values - is actionable knowledge" (Dyson/Gilder/Keyworth/Toffler 1994). Manuell Castells has added to the notion that in the information society the economy is based on information the idea that the information society is a network society, the network organization of society would be advanced by information technology. Hence for Castells an indicator for the informational character of society is the degree of networking in social systems. "The term 'informational' indicates the attribute of a specific form of social organization in which information generation, processing, and transmission become the fundamental sources of productivity and power because of new technological conditions emerging in this historical period. [...] As an historical trend, dominant functions and processes in the Information Age are increasingly organized around networks. Networks constitute the new social morphology of our societies, and the diffusion of network logic substantially modifies the operation and outcomes in processes of production, experience, power, and culture. While the networking form of social organization has existed in other times and spaces, the new information technology paradigm provides the material basis for its pervasive expansion throughout the entire social structure" (Castells 2000: 19, 500).

The shift towards the knowledge-based society has resulted in an increasing orientation of empirical sociological research and statistical analysis towards developing statistical indicators of the knowledgebased character of the economy and society (e.g. ASEAN 2002, Beirat für Wirschafts- und Sozialfragen 2002, BISER 2004, Council of the European Union 2003, EITO 2005, ESIS 2000, Eurobarometer 1997, 1998, 2000a, 2000b, 2000c, 2002; Eurostat 2002, 2003a, 2003b, Garland 2003, OECD 2002, 2004; SIBIS 2002/2003, UNCTAD 2003, 2004; UNESCO Institute for Statistics 2003, WSIS 2005).

The strategic goal of the European Union for 2010 that has been set at the Lisbon European Council in March 2000 is to "become the most competitive and dynamic knowledge-based economy in the world, capable of sustainable economic growth with more and better jobs and greater social cohesion". In order to reach this goal the EU has formulated the action plans eEurope 2002 and eEurope 2005. The goal is to make available the advantages of the information society to all citizens and businesses. In the action plan "eEurope 2005: An Information Society For All" the Commission of the European Communities (2002a: 3) defined priorities by arguing that by 2005, Europe should have "modern online public services, egovernment, e-learning services, e-health services, a dynamic e-business environment and, as an enabler for these widespread availability of broadband access, a secure information infrastructure". In 2005 the European Commission adopted the initiative "i2010: European Information Society 2010" to foster growth and jobs in the information society and media industries. The three main goals are to create an open and competitive single market for information society and media services within the EU, to increase EU investment in research on information and communication technologies (ICT) by $80 \%$, and to promote an inclusive European information society. 
In order to benchmark the success of the member states in achieving the goals defined in the eEurope action plans the European Council has defined main indicators plus supplementary indicators in the areas of 1. Citizens' access to and use of the Internet, 2. Enterprises' access to and use of ICTs, 3. Internet access costs, 4. E-Government, 5. E-Learning, 6. E-Health, 7.Buying and selling on-line, 8. E-Business readiness, 9. Internet users' experiences and usage regarding ICT-security, 10. Broadband penetration (Commission of the European Communities 2002a, Council of the European Union 2003). There are 16 policy indicators and 25 supplementary indicators. For benchmarking eEurope 2002 there were 23 indicators. The difference is that for eEurope 2005 the differentiation between policy indicators and supplementary indicators has been introduced for "making it easier to draw attention to results" (Council of the European Union 2003). Here is an overview of the indicators of eEurope 2005 (according to Council of the European Union 2003).

Citizens' Access to and Use of the Internet

Policy indicators:

A.1. Percentage of households or individuals having access to the Internet at home

A.2. Percentage of individuals regularly using the Internet

Supplementary indicators:

A.3. Percentage of households or individuals with access to the Internet broken down by device for accessing via PC, digital TV, mobile device (include all forms of mobile access; handheld computer, mobile phone, identifying $3 \mathrm{G}$ (UMTS) Separately when available)

A.4. Percentage of individuals with access to the Internet broken down by place of access (home, workplace, place of education, Internet cafe, PIAP etc)

A.5. Percentage of individuals using the Internet for specific purposes (broken down by purposes: sending/receiving emails, finding information about goods and services, reading/downloading online newspapers, playing/downloading games and music, internet banking) in the previous 3 months A.6. Percentage of households or individuals connected in Objective 1 regions.

B. Enterprises' Access to and Use of ICTs

Policy indicators:

B.1. Percentage of persons employed using computers connected to the Internet, in their normal work routine

Supplementary indicators:

B.2. Percentage of enterprises having access to the Internet

B.3. Percentage of enterprises having a website/homepage

B.4. Percentage of enterprises using Intranet/Extranet

B.5. Percentage of enterprises with persons employed working part of their time away from enterprise premises and accessing the enterprise's IT systems from there.

C. Internet Access Costs

Policy indicator:

C.1. Costs of Internet access broken down by different frequency of use: $20,30,40 \mathrm{hrs} / \mathrm{month}$, unmetered rates 
Supplementary indicators:

C.2. Identification of cheapest broadband access by type in each Member State.

D. E-Government

Policy indicator:

D.1. No. of basic public services fully available on-line (20 basic services as approved by the Internal Market/Consumers/Tourism Council of 12 March 2001 for the first eEurope benchmarking exercise).

Supplementary indicators:

D.2. Percentage of individuals using the Internet for interacting with public authorities broken down by purpose (purposes: obtaining information, obtaining forms, returning filled in forms

D.3. Percentage of enterprises using the Internet for interacting with public authorities broken down by purpose (purposes: obtaining information, obtaining forms, returning filled in forms, full electronic case handling)

D.4. No. of available basic public on-line services with integrated digital back office processes

D.5. Public procurement processes that are fully carried out online (electronically integrated) in \% (by value) of overall public procurement

D.6. Percentage of public authorities using open source software

\section{E. E-Learning}

Policy indicator:

E.1. Number of pupils per computer with Internet connection (broadband/non-broadband)

Supplementary indicators:

E.2. Percentage of individuals having used the Internet in relation to training and educational purposes broken down by: formalised educational activities (school, university etc.); post-educational courses; other courses related specifically to employment opportunities

E.3. Percentage of enterprises using e-learning applications for training and education of employees

F. E-Health

Policy indicators:

F.1. Percentage of Population (aged 16 and over) using Internet to seek health information whether for themselves or others

F.2. Percentage of general practitioners using electronic patient records

G. Buying and Selling On-line

Policy indicator:

G.1. Percentage of enterprises' total turnover from e-commerce

Supplementary indicators:

G.2. Percentage of individuals having ordered/bought goods or services for private use over the Internet in the last 3 months

G.3. Percentage of enterprises having received orders on-line

G.4. Percentage of enterprises having received on-line payments for Internet sales

G.5. Percentage of enterprises having purchased on-line

H. E-Business Readiness 
Policy Indicator:

E-Business index (composite indicator)

Components of Index:

(a) Adoption of ICT by business

a1. Percentage of enterprises that use Internet

a2. Percentage of enterprises that have a web site/home page

a3. Percentage of enterprises that use at least two security facilities at the time of the survey

a4. Percentage of total number of persons employed using computers in their normal work routine (at least once a week)

a5. Percentage of enterprises having a broadband connection to the Internet

a6. Percentage of enterprises with a LAN and using an Intranet or Extranet

(b) Use of ICT by business

b1. Percentage of enterprises that have purchased products / services' via the internet, EDI or any other computer mediated network where these are $>1 \%$ of total purchases

b2. Percentage of enterprises that have received orders via the internet, EDI or any other computer mediated network where these are $>1 \%$ of total turnover

b3. Percentage of enterprises whose IT systems for managing orders or purchases are linked automatically with other internal IT systems.

b4. Percentage enterprises whose IT systems are linked automatically to IT systems of suppliers or customers outside their enterprise group

b5. Percentage of enterprises with Internet access using the internet for banking and financial services

b6. Percentage of enterprises that have sold products to other enterprises via a presence on specialised internet market places

I. Internet Users' Experience and Usage Regarding ICT-Security

Policy indicators:

I.1. Percentage of individuals with Internet access having encountered security problems

I.2. Percentage of enterprises with Internet access having encountered security problems

Supplementary indicators:

I.3. Percentage of individuals having taken ICT security precautions within the last three months

I.4. Percentage of enterprises having taken ICT precautions

I.5. Percentage of individuals and enterprises that have installed security devices on their PCs and updated them within the last three months

\section{J. Broadband Penetration}

Policy indicators:

J.1. Availability of broadband access measured by percentage of total households or individuals by access platform

J.2. Percentage of enterprises with broadband access

J.3. Percentage of households or individuals with broadband access

J.4. Percentage of public administrations with broadband access

Supplementary indicators:

J.5. Difference between availability and penetration of broadband access broken down by type of access

J.6. Percentage of households or individuals equipped with home networking connections. 
Eurostat (2003b) has grouped these indicators of the information society into seven categories (for indicators on economic aspects of the European information society cf. also Eurostat 2003a: 73-85): 1. ICT sector, 2. ICT market and external trade, 3. ICT penetration, 4. ICT usage in households, 5. ICT usage in enterprises, 6. ICT and education, training, and skills; 7. ICT government and health.

The OECD has suggested a definition and classification of the ICT sector as "a combination of manufacturing and services industries whose products capture, transmit or display data and information electronically" (OECD 2004: 1, cf. also OECD 2002) on which measurements of the digital economy can be based. The United Nations Educational, Scientific and Cultural Organization (UNESCO Institute for Statistics 2003) is interested in cross-national comparative information society indicators and has suggested such measurements for the areas of ICT infrastructure, ICT access and use, ICT and education, ICT and culture, ICT and science \& technology. The United Nations Conference on Trade and Development (UNCTAD) has focused on measuring e-business and e-commerce (UNCTAD 2003, 2004). In the USA the US Census Bureau focuses on measuring the Electronic Economy (E-Stats, http://www.census.gov/eos/www/ebusiness614.htm, Mesenbourg 2000). The Association of South East Asian Nations (ASEAN) has been discussing how to best measure the digital economy (ASEAN 2002).

There have been a number of European research projects on information society indicators such as the "European Survey of Information Society" (ESIS, funded by Promise - Promoting the Information Society in Europe, 1997-2001, cf. ESIS 2000), "European Indicators, Cyberspace and the Science-TechnologyEconomy System" (IST-1999-20350) that aimed at deriving indicators and statistics about the European Science-Technology-Economy-System in Internet by making use of agent technology, "Benchmarking the Information Society e-Europe Indicators for European Regions" (IST-2000-30187) that aimed at benchmarking the relative progress of European Region in information society development, "Statistical Indicators for Benchmarking the Information Society" (IST-2000-26276), "Statistical Indicators for the Information Society-Measuring Forms, Content, Strategy and Impacts of B2B E-Commerce" (IST-200132193) that aimed at developing innovative indicators for understanding B2B e-commerce, "Knowledge Economy Indicators: Development of Innovative and Reliable Indicator Systems" (FP6-POLICIES-502529) that aims to develop and improve indicators for the knowledge economy and covers 30 European countries. The European Information Technology Observatory that since 2003 has published annual reports on information society statistics (EITO 2005) is funded by commercial sponsors and supported by the European Commission and the OECD. Such projects have provided important insights for measuring the European information society, but neither of them has made an effort of connecting theories, concept, principles, and indicators of sustainability to issues concerning the information society. The notion of a sustainable knowledge society and the elaboration of theoretical concepts, principles, as well as indicators that underpin such a notion is missing in these projects.

ESIS (2000) has focused on statistics in two main areas of analysis: 1. Telecommunication and telephone lines, 2. PCs, Internet, e-commerce and television. The Statistical Indicators for Benchmarking the Information Society (SIBIS 2002/2003) project has published information society statistics in 9 areas: basic access and usage, information security, e-commerce, e-work, e-government, e-health, digital literacy, learning and training, digital divides. The "Benchmarking the Information Society e-Europe Indicators for European Regions" project (BISER 2004) used a total of 20 indicators in the two areas of population-side indicators and establishment-side indicators for benchmarking the information society in 28 selected European regions.

There was a World Summit of the Information Society (WSIS) thematic meeting on "Measuring the Information Society" from February 7-9, 2005 in Geneva in which possibilities for an international unification of information society indicators were discussed. The final conclusions suggest 42 indicators in 3 areas: 1 . Infrastructure and access, 2. Access and use of ICTs by households and individuals, 3. Access 
and use of ICTS by businesses (WSIS 2005).

1. Infrastructure and access

A-1 Fixed telephone lines per 100 inhabitants

A-2 Mobile cellular subscribers per 100 inhabitants

A-3 Computers per 100 inhabitants

A-4 Internet subscribers per 100 inhabitants

A-5 Broadband Internet subscribers per 100 inhabitants

A-6 International Internet bandwidth per inhabitant

A-7 Percentage of population covered by mobile cellular telephony

A-8 Internet access tariffs ( 20 hours per month), in US\$, and as a percentage of per capita income A-9 Mobile cellular tariffs (100 minutes of use per month), in US\$, and as a percentage of per capita income

A-10 Percentage of localities with public Internet access centres (PIACs) by number of inhabitants (rural/urban)

A-11 Radio sets per 100 inhabitants

A-12 Television sets per 100 inhabitants

2. Access and use of ICTs by households and individuals

$\mathrm{HH}-1$ Proportion of households with a radio

$\mathrm{HH}-2$ Proportion of households with a TV

$\mathrm{HH}-3$ Proportion of households with a fixed line telephone

$\mathrm{HH}-4$ Proportion of households with a mobile cellular telephone

$\mathrm{HH}-5$ Proportion of households with a computer

HH-6 Proportion of individuals that used a computer (from any location) in the last 12 months

$\mathrm{HH}-7$ Proportion of households with Internet access at home

$\mathrm{HH}-8$ Proportion of individuals that used the Internet (from any location) in the last 12 months

$\mathrm{HH}-9$ Location of individual use of the Internet from all locations in the last 12 months

Response categories:

At home, At work, Place of education, At another person's home, Free Public Internet Access Centre (specific denomination depends on national practices), Charged Public Internet Access Centre (specific denomination depends on national practices), Others

$\mathrm{HH}-10$ Internet activities undertaken by individuals in the last 12 months

Response categories:

For getting information: About goods or services, Related to health or health services, From government organisations/public authorities via websites or e-mail, Other information or general Web browsing, For communicating, Purchasing or ordering goods or services, Internet banking or other financial services, For education and learning, For dealing with government organisations/public authorities, For leisure activities, Playing/downloading video or computer games, Obtaining movies, music or software,

Reading/downloading electronic books, newspapers or magazines, Other leisure activities

$\mathrm{HH}-11$ Proportion of individuals with use of a mobile telephone

$\mathrm{HH}-12$ Proportion of households with access to the Internet by type of access from home Response categories should allow an aggregation to narrowband and broadband, where broadband will exclude slower speed technologies, such as dial-up modem, ISDN and most 2G mobile phone access, and which will usually result in a speed of at least $256 \mathrm{kbit} / \mathrm{s}$.

$\mathrm{HH}-13$ Frequency of individual access to the Internet in the last 12 months (from any location) Response categories: at least once a day, at least once a week but not every day, at least once a month but not every week, less than once a month HH-R1 Proportion of households with electricity 1 
3. Access and use of ICTs by businesses

B-1 Proportion of businesses using computers

B-2 Proportion of employees using computers

B-3 Proportion of businesses using the Internet

B-4 Proportion of employees using the Internet

B-5 Proportion of businesses with a website (or web presence where the business has control over the content)

B-6 Proportion of businesses with an intranet

B-7 Proportion of businesses receiving orders over the Internet

B-8 Proportion of businesses placing orders over the Internet

B-9 Proportion of businesses accessing the Internet by modes of access

Response categories should allow an aggregation to narrowband and broadband, where broadband will exclude slower speed technologies, such as dial-up modem, ISDN and most 2G mobile phone access, and which will usually result in a speed of at least $256 \mathrm{kbit} / \mathrm{s}$.

B-10 Proportion of businesses with a Local Area Network (LAN)

B-11 Proportion of businesses with an extranet

B-12 Proportion of businesses using the Internet by type of activity

Response categories: Internet e-mail, Getting information: o About goods or services o From government organisations/public authorities via websites or e-mail o Other information searches or research activities, Performing Internet banking or accessing other financial services, Dealing with government

ICT-1 Proportion of total workforce involved in the ICT sector

ICT-2 Value added in the ICT sector (as a percentage of total value added)

ICT-3 ICT goods imports as percentage of total imports

ICT-4 ICT goods exports as percentage of total exports

\section{2. Measuring Sustainability}

As theoretical frameworks for sustainability indicators frequently project-based frameworks or the OECD's Pressure-State-Response (PSR) model are used. The first approach assumes that inputs are provided for the implementation of various project components that are used for implementing a project that produces outputs. In this approach the outputs have outcomes and impacts. Indicators are classified as input indicatros, output indicators, outcome indicators, and impact indicators. In the PSR framework (OECD 1994) one assumes that human activities exert pressures on the environment and change its quality and the quantity of natural resources. Information about these changes reaches the decisionmaking instances in society, which respond through policies. These societal responses strive to result in a change of human behaviour that in turn results in an altered state of the environment. Changes in this model have resulted in a stress on social, economic, and institutional aspects besides ecological ones that have been termed driving forces (Virtual Research and Development Centre 2001) and the inclusion of impact indicators, resulting in a Driving Forces-Pressures-State-Impact-Response (DPSIR) model (ibid.). When the United Nations Commission on Sustainable Development (UNCSD) initiated the development of sustainability indicators in 1995, it based its work on the PSR model. In 1996 the UNCSD developed a list of 134 indicators of sustainability (UNCSD 1996). Later the UNCSD chose to classify indicators according to thematic areas. In the European Union Eurostat set of indicators of sustainable development is based on the DPSR model.

Sustainability indicators such as the Ecological Footprint (Holmberg et al. 1999), the Pilot Environmental Sustainability Index (World Economic Forum 2000) the Living Planet Index (WWF/NEF/WCMC 1999), the early OECD core set of environmental indicators (OECD 1994), Eurostat's Environmental Pressure Indicators (TAU/EMAIL 2001), and Material Flow Analyses focus on the ecological dimension of sustainability. The European Environmental Bureau, Friends of Nature International, and Friends of the Earth Europe (2001) stress ecological aspects and identify a total of 11 
indicators in the areas of climate change, nature \& biodiversity, environment \& human health, waste \& resources. Many of these indicators are based on the OECD's Pressure-State-Response (PSR) model that assumes that human activities exert pressures on the environment that change the latter's state which results in responses of society in the form of policy measures.

The Ecological Footprint is a method for estimating the biologically productive area necessary to support current consumption patterns, given prevailing technical and economic processes. By comparing human impact with the planet's limited bioproductive area, this method tests a basic ecological condition for sustainability. The Ecological Footprint calculations have so far included land for energy supply, food, forest products, and the built environment, degraded areas, and sea space for fishing. For the waste side the land needed for sequestering $\mathrm{CO} 2$ is included in the Ecological Footprint (Holmberg et al., 1999).

The Pilot Environmental Sustainability Index is constructed in a hierarchical fashion. The five components describe the current environmental systems, stresses to those systems; the vulnerability of human populations to environmental disturbances and disasters, the social and institutional capacity to respond to environmental problems, and global stewardship, or the degree to which an economy behaves responsibly with respect to other economies. These components consist of a number of factors (for example, urban air quality, air pollution, basic sustenance, science and technical capacity, and contribution to international cooperation) considered to constitute the most fundamental building blocks of each component. For each factor, variables (for example, urban NO2 and SO2 concentration, SO2 and $\mathrm{NO}$ emissions per land area, percentage of households with electricity, scientific and technical articles per million populations, and number of memberships on environmental intergovernmental organizations) are identified to serve as measures (World Economic Forum 2000).

The Living Planet Index (LPI) is an index that primarily measures abundance - the area of the world's forests and the populations of different marine and freshwater species. Thus it is essentially measuring natural wealth and, particularly, how this natural wealth has changed over time. The LPI is an aggregate of three different indicators of the state of natural ecosystems. These are: the area of natural forest cover around the world, populations of freshwater species around the world, and populations of marine species around the world. (WWF/NEF/WCMC 1999)

In 1994, the OECD Environmental Policy Committee finalized the first part of a three-part work program. They developed a core set of environmental indicators to be used in environmental performance reviews in OECD countries (OECD 1994). The issues include climate change, ozone layer depletion, eutrophication, acidification, toxic contamination, urban environmental quality, biodiversity, landscape, waste, water resources, forest resources, fish resources, and soil degradation.

Eurostat (the statistical department of the EU) has developed a system of environmental pressure indicators. They show the important trends for ten policy fields: air pollution, climate change, loss of biodiversity, marine environment and coastal zones, ozone layer depletion, resource depletion, dispersion of toxic substances, urban environmental problems, waste, and water pollution and water resources (cf. TAU/EMAIL 2001).

Material Flows Analysis constitutes another type of ecological sustainability indicators. Because all environmental problems are ultimately related to flows of materials, World Resources Institute (WRI) is developing indicators that capture a picture of the material flows through industrial economies: industrial minerals, construction materials, metals, chemicals, infrastructure, fossil fuels, soil erosion, renewables, semi-manufactures, finished products, and the hidden flows (WRI 2000). Material flow accounting can systematically track the physical flows of natural resources through extraction, production, fabrication, use and recycling, and final disposal, accounting for all losses along the way. 
The discourse on sustainability has shifted from an early ecological focus towards the inclusion of economic, political, cultural, and social issues. Hence there are not only ecological indicators, but also ones that try to cover the whole bandwidth of societal issues concerning sustainability. Such broad indicators of sustainability covering a wide range of topics and societal areas are e.g. the United Nations Commission of Sustainable Development's (UNCSD) set of indicators of sustainable development, Eurostat's sustainability indicators, the World Development Indicators that are based on the Millennium Declaration, the sustainability indicators suggested by the Wuppertal Institute, the Genuine Progess Indicator, and the Barometer of Sustainability.

At its Third Session in 1995, the Commission on Sustainable Development (CSD) initiated the development of indicators for the measurement of sustainable development. A working list of 134 indicators was selected and 22 countries volunteered to test their applicability. The goal for 2001 was the development of a standardized set of indicators available as a tool to measure progress towards sustainable development. As such a standardization the United Nations Division for Sustainable Development (UNDSD 2001) suggests a total of 57 indicators in four key areas: social, economic, environmental, institutional.

Based on the UN indicators Eurostat (2001) developed 64 indicators of sustainability in the same four main areas as UNDSD. Eurostat's first pilot study on sustainability indicators was published in 1997 (Eurostat 1997). Figure 3 compares the EU and the UN sustainability indicators. The Wuppertal Institute has argued that besides indicators focusing on these four dimensions, interlinkage indicators should be introduced (environmental-economic, environmental-social, economic-social interlinkage indicators) (Spangenberg/Bonniot 1998, Spangenberg et al. 2002).

In 1996, the Development Assistance Committee of the Organization for Economic Co-operation and Development initiated an effort for developing sustainability indicators at an international level, the indicators for the then called International Development Goals (IDGs) initiative, inviting the United Nations, the World Bank and the International Monetary Fund to become partners. Over the four years that followed, five working groups discussed indicators for issues such as poverty, education, gender, infant and child mortality, maternal health, HIVIAIDS, malaria and other diseases, environment, and global partnership. At a later stage, the name of the targets changed from the IDGs to the MDGs (the Millennium Development Goals). Each goal has a number of targets identified, which are more specific in their character. There are 8 goals and 18 targets of the Millennium Declaration, for each target a set of indicators for monitoring progress is identified, resulting in a total of 48 major indicators that make up the World Development Indicators (World Bank 2005b). The development of these indicators in specific nations is monitored and the results are published regularly (http://devdata.worldbank.org/data-query/, http://www.worldbank.org/data/wdi2005/, cf. also United Nations 2005). The World Bank distinguishes six classes of indicators relating to different topics: world view, people, environment, economy, states and markets, and global links (World Bank 2005b).

In 1995, Redefining Progress created the Genuine Progress Indicator. It starts with the same accounting framework as the GDP, but then makes some crucial distinctions: It adds in the economic contributions of household and volunteer work, but subtracts factors such as crime, pollution, and family breakdown (Redefining Progress 1999).

The Barometer of Sustainability is a tool for combining indicators and displaying the results. Its key features are:

- Two axes, one for human well-being, the other for ecosystem well-being. This enables each set of indicators to be combined independently, keeping them separate to allow analysis of people-ecosystem interactions. 
- The axis with the lower score overrides the other axis. This prevents a high score for

human well-being from offsetting a low score for ecosystem well-being (or vice versa) -reflecting the view that people and the ecosystem are equally important and that sustainable development must improve and maintain the well-being of both.

- Each axis is divided into five bands. This allows users to define not just the end points of the scale but intermediate points as well, for greater flexibility and control of the scale (Prescott-Allen 1999) .

\begin{tabular}{|c|c|c|c|c|c|}
\hline \multicolumn{6}{|c|}{ SOCIAL DIMENSION } \\
\hline UN THEME & SUBTHEME & & ROSTAT INDICATOR & UN INDICATOR & EVALUATION \\
\hline \multirow{7}{*}{ 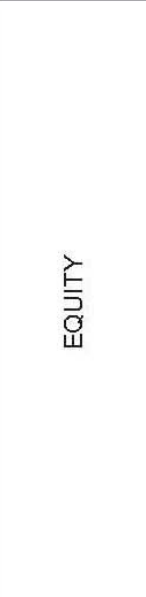 } & \multirow{5}{*}{$\begin{array}{l}\frac{Z}{0} \\
\frac{0}{0} \\
0\end{array}$} & $\operatorname{soc} 1$ & $\begin{array}{l}\text { Population living below } \\
\text { poverty line }\end{array}$ & $\begin{array}{l}\% \text { of population living } \\
\text { below poverty line }\end{array}$ & Unchanged \\
\hline & & $\operatorname{soc} 2$ & Measures of income inequality & Gini index of income inequality & Unchanged \\
\hline & & $\operatorname{soc} 3$ & Unemployment rate & Unemployment rate & Unchanged \\
\hline & & $\operatorname{soc} 4$ & Youth unemployment rate & - & Added \\
\hline & & $\operatorname{soc} 5$ & Social benefits per capita & - & Added \\
\hline & Gender equality & $\operatorname{soc} 6$ & Female to male wage ratio & $\begin{array}{l}\text { Average of female } \\
\text { wage to male wage }\end{array}$ & Unchanged \\
\hline & Child welfare & $\operatorname{SOC} 7$ & Child welfare & $\begin{array}{l}\% \text { of children under age } 1 \\
\text { living outside their own home }\end{array}$ & Changed \\
\hline \multirow{7}{*}{$\frac{\text { I }}{\stackrel{\Xi}{\leftrightarrows}}$} & Nutrition status & $\operatorname{soc} 8$ & Nutritional status of population & Nutritional status of children & Modified \\
\hline & Illness & $\operatorname{soc} 9$ & $\begin{array}{l}\text { Mortality due to selected } \\
\text { key illnesses }\end{array}$ & $\begin{array}{l}\text { Mortality and mortality due to } \\
\text { selected key illnesses }\end{array}$ & Changed \\
\hline & \multirow[t]{2}{*}{ Mortality } & $\operatorname{soc} 10$ & Infant Mortality & $\begin{array}{l}\text { Mortality rate unde } \\
5 \text { years old }\end{array}$ & Modified \\
\hline & & SOC 11 & Life expectancy at birth & Life expectancy at birth & Unchanged \\
\hline & Sanitation & $\operatorname{SOC} 12$ & $\begin{array}{l}\text { Population connected to } \\
\text { sanitation system }\end{array}$ & $\begin{array}{l}\% \text { population with adequate } \\
\text { sewage disposal facilities }\end{array}$ & Modified \\
\hline & \multirow{2}{*}{$\begin{array}{l}\text { Healthcare } \\
\text { delivery }\end{array}$} & $\operatorname{SOC} 13$ & National health expenditure & $\begin{array}{l}\% \text { Population with access to } \\
\text { primary health care facilities }\end{array}$ & Changed \\
\hline & & $\operatorname{soc} 14$ & $\begin{array}{l}\text { Immunisation against } \\
\text { childhood diseases }\end{array}$ & $\begin{array}{l}\text { Immunisation against infectious } \\
\text { childhood diseases }\end{array}$ & Unchanged \\
\hline \multirow{2}{*}{ 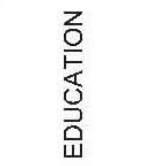 } & Education level & $\operatorname{SOC} 15$ & $\begin{array}{l}\text { Levels of } \\
\text { educational attainment }\end{array}$ & $\begin{array}{c}\text { Secondary or Primary School } \\
\text { completion ratio }\end{array}$ & Modified \\
\hline & Literacy & $\operatorname{soc} 16$ & Low qualification levels & Adult literacy rate & Modified \\
\hline \multirow{2}{*}{ 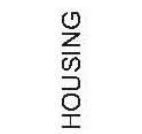 } & \multirow{2}{*}{$\begin{array}{l}\text { Living } \\
\text { conditions }\end{array}$} & $\operatorname{SOC} 17$ & Number of rooms per capita & Floor area per person & Modified \\
\hline & & $\operatorname{soc} 18$ & Household composition & - & Added \\
\hline SECURITY & Crime & $\operatorname{soc} 19$ & Reported crimes & $\begin{array}{l}\text { No. of Reported crimes } \\
\text { per } 1000 \text { population }\end{array}$ & Unchanged \\
\hline \multirow{3}{*}{$\begin{array}{l}z \\
\frac{z}{b} \\
\frac{1}{J} \\
\frac{0}{0} \\
0\end{array}$} & \multirow{3}{*}{$\begin{array}{l}\text { Population } \\
\text { change }\end{array}$} & $\operatorname{soc} 20$ & Population growth rate & Population growth rate & Unchanged \\
\hline & & $\operatorname{soc} 21$ & Population density & $\begin{array}{l}\text { Population of urban formal } \\
\text { and informal settlements }\end{array}$ & Changed \\
\hline & & $\operatorname{soc} 22$ & Net migration rate & - & Added \\
\hline
\end{tabular}




\begin{tabular}{|c|c|c|c|c|c|}
\hline \multicolumn{6}{|c|}{ ENVIRONMENTAL DIMENSION } \\
\hline UN THEME & SUBTHEME & \multicolumn{2}{|c|}{ EUROSTAT INDICATOR } & UN INDICATOR & EVALUATION \\
\hline \multirow{3}{*}{ 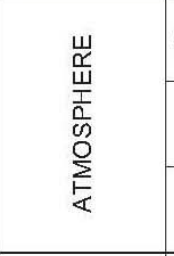 } & Climate change & ENV 1 & $\begin{array}{l}\text { Per capita emissions of } \\
\text { greenhouse gases }\end{array}$ & $\begin{array}{l}\text { Emissions of } \\
\text { greenhouse gases }\end{array}$ & Unchanged \\
\hline & $\begin{array}{l}\text { Ozone layer } \\
\text { depletion }\end{array}$ & ENV 2 & $\begin{array}{l}\text { Consumption of ozone } \\
\text { depleting substances }\end{array}$ & $\begin{array}{l}\text { Consumption of ozon } \\
\text { depleting substances }\end{array}$ & Unchanged \\
\hline & Air quality & ENV 3 & Air pollutants in urban areas & $\begin{array}{l}\text { Ambient concentration of } \\
\text { pollutants in urban areas }\end{array}$ & Unchanged \\
\hline \multirow{6}{*}{ 号 } & \multirow{3}{*}{ Agriculture } & ENV 4 & $\begin{array}{l}\text { Agricultural area and } \\
\text { organic farming }\end{array}$ & $\begin{array}{c}\text { Arable and permanent } \\
\text { crop area }\end{array}$ & Changed \\
\hline & & ENV 5 & Nitrogen balances & Use of fertilisers & Modified \\
\hline & & ENV 6 & Use of agricultural pesticides & Use of agricultural pesticides & Unchanged \\
\hline & \multirow{2}{*}{ Forests } & ENV 7 & Total forest area & Total forest area & Unchanged \\
\hline & & ENV 8 & Wood harvesting ratio & Wood Harvesting Intensity & Unchanged \\
\hline & Urbanisation & ENV 9 & Growth of built-up area & $\begin{array}{l}\text { Area of urban formal and } \\
\text { informal settlements }\end{array}$ & Changed \\
\hline \multirow{2}{*}{$\begin{array}{c}\text { OCEAN, SEA } \\
\text { AND } \\
\text { COASTS }\end{array}$} & Coastal zone & ENV 10 & $\begin{array}{l}\text { Eutrophication of coasts and } \\
\text { marine waters }\end{array}$ & $\begin{array}{c}\text { Algae concentratio } \\
\text { in coastal waters }\end{array}$ & Changed \\
\hline & Fisheries & ENV 11 & $\begin{array}{l}\text { Fish catches by selected } \\
\text { over exploited species }\end{array}$ & Annual catch by major species & Changed \\
\hline \multirow{3}{*}{ 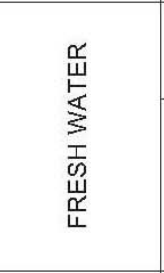 } & Water quantity & ENV 12 & Intensity of water use & $\begin{array}{c}\text { Annual withdrawal of ground and } \\
\text { surface water as } \\
\% \text { of total available water }\end{array}$ & Unchanged \\
\hline & \multirow{2}{*}{ Water quality } & ENV 13 & $\begin{array}{l}\text { BOD concentration in } \\
\text { selected rivers }\end{array}$ & $\begin{array}{l}\text { BOD concentration in water } \\
\text { bodies }\end{array}$ & Unchanged \\
\hline & & ENV 14 & Quality of bathing water & $\begin{array}{c}\text { Concentration of faecal coliform } \\
\text { in freshwater }\end{array}$ & Modified \\
\hline \multirow{2}{*}{ 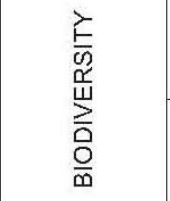 } & Ecosystem & ENV 15 & $\begin{array}{l}\text { Protected area as a } \\
\% \text { of total area }\end{array}$ & $\begin{array}{c}\text { Protected area as a } \% \text { of total } \\
\text { area }\end{array}$ & Unchanged \\
\hline & Species & ENV 16 & Number of threatened species & $\begin{array}{l}\text { Abundance of selected } \\
\text { key species }\end{array}$ & Changed \\
\hline
\end{tabular}




\begin{tabular}{|c|c|c|c|c|c|}
\hline \multicolumn{6}{|c|}{ ECONOMIC DIMENSION } \\
\hline UN THEME & SUBTHEME & \multicolumn{2}{|c|}{ EUROSTAT INDICATOR } & \multirow{2}{*}{$\begin{array}{l}\text { UN INDICATOR } \\
\text { GNP per capita }\end{array}$} & \multirow{2}{*}{$\begin{array}{c}\text { EVALUATION } \\
\text { Modified }\end{array}$} \\
\hline \multirow{8}{*}{ 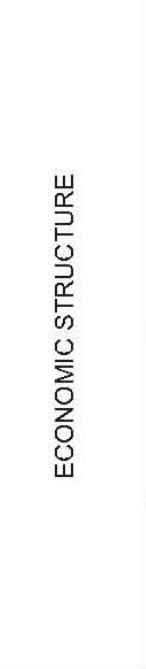 } & \multirow{4}{*}{ 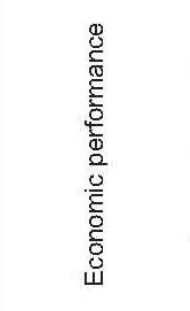 } & ECON 1 & Per capita GDP & & \\
\hline & & ECON 2 & Investment share in GDP & Investment share in GNP & Modified \\
\hline & & ECON 3 & Value added by main sector & - & Added \\
\hline & & ECON 4 & Inflation rate & - & Added \\
\hline & 힝 & ECON 5 & Net current account & $\begin{array}{l}\text { Balance of trade in } \\
\text { goods and services }\end{array}$ & Unchanged \\
\hline & & ECON 6 & EU and international markets & - & Added \\
\hline & $\frac{\bar{\pi}}{0} \frac{0}{2}$ & ECON 7 & Public debt & Debt/GNP & Modified \\
\hline & 焉 $\frac{\pi}{6}$ & ECON 8 & Aid to developing countries & $\begin{array}{l}\text { Total ODA given or } \\
\text { received as \% of GNP }\end{array}$ & Unchanged \\
\hline \multirow{13}{*}{ 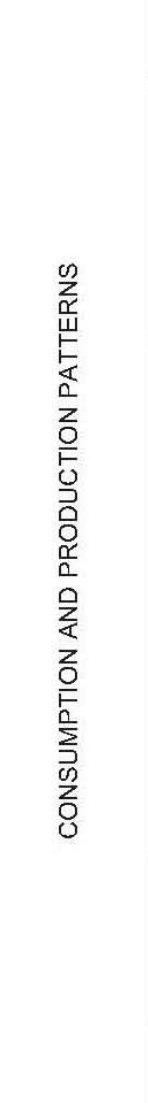 } & $\begin{array}{c}\text { Material } \\
\text { consumption }\end{array}$ & ECON 9 & Material Consumption & Intensity of Material Use & Unchanged \\
\hline & 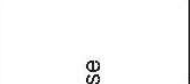 & ECON 10 & $\begin{array}{l}\text { Per capita Gross inland } \\
\text { energy consumption }\end{array}$ & $\begin{array}{c}\text { Annual energy consumption } \\
\text { per capita }\end{array}$ & Unchanged \\
\hline & के & ECON 11 & Renewable energy sources & $\begin{array}{l}\text { Share of consumption of } \\
\text { renewable resources }\end{array}$ & Unchanged \\
\hline & & ECON 12 & Intensity of energy use & Intensity of energy use & Unchanged \\
\hline & \multirow{6}{*}{ 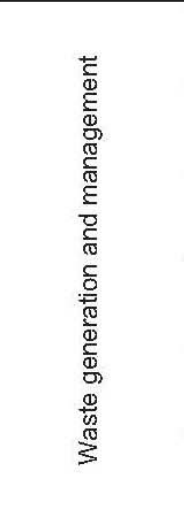 } & ECON 13 & $\begin{array}{l}\text { Generation and disposal } \\
\text { of municipal waste }\end{array}$ & $\begin{array}{l}\text { Generation of industrial and } \\
\text { municipal solid waste }\end{array}$ & Modified \\
\hline & & ECON 14 & Generation of industrial waste & - & Added \\
\hline & & ECON 15 & $\begin{array}{l}\text { Generation and disposal } \\
\text { of hazardous waste }\end{array}$ & $\begin{array}{c}\text { Generation of } \\
\text { hazardous waste }\end{array}$ & Unchanged \\
\hline & & ECON 16 & $\begin{array}{l}\text { Generation and disposal } \\
\text { of radioactive waste }\end{array}$ & $\begin{array}{l}\text { Generation of } \\
\text { radioactive waste }\end{array}$ & Unchanged \\
\hline & & ECON 17 & $\begin{array}{l}\text { Recycling of waste: } \\
\text { paper and glass }\end{array}$ & $\begin{array}{l}\text { Waste Recycling } \\
\text { and Reuse }\end{array}$ & Unchanged \\
\hline & & ECON 18 & $\begin{array}{l}\text { Waste treatment and } \\
\text { disposal facilities }\end{array}$ & - & Added \\
\hline & \multirow[t]{2}{*}{ Transportation } & ECON 19 & Passenger transport by mode & $\begin{array}{l}\text { Distanced travelled per } \\
\text { capita per mode of transport }\end{array}$ & Unchanged \\
\hline & & ECON 20 & Freight transport by mode & - & Added \\
\hline & $\begin{array}{c}\text { Environmental } \\
\text { Protection }\end{array}$ & ECON 21 & $\begin{array}{l}\text { Environmental protection } \\
\text { expenditures }\end{array}$ & - & Added \\
\hline
\end{tabular}




\begin{tabular}{|c|c|c|c|c|c|}
\hline \multicolumn{6}{|c|}{ INSTITUTIONAL DIMENSION } \\
\hline UN THEME & SUBTHEME & & ROSTAT INDICATOR & UN INDICATOR & EVALUATION \\
\hline $\begin{array}{l}\text { INSTITUTIONAL } \\
\text { FRAMEWORK }\end{array}$ & \multicolumn{3}{|c|}{$\begin{array}{l}\text { Member States contributions on national SDI experiences } \\
\text { (Annex to Institutional Dimension) }\end{array}$} & National Sustainable Developmer & Changed \\
\hline \multirow{4}{*}{ 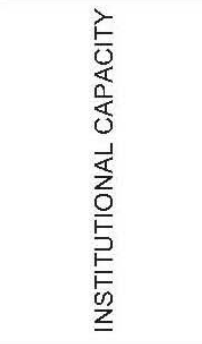 } & $\begin{array}{l}\text { Information } \\
\text { access }\end{array}$ & INST 1 & Internet access & $\begin{array}{l}\text { Number of radios or internet } \\
\text { accounts per } 1000 \text { inhabitants }\end{array}$ & Modified \\
\hline & $\begin{array}{l}\text { Communication } \\
\text { infrastructure }\end{array}$ & INST 2 & Communication infrastructure & $\begin{array}{l}\text { Main telephone lines and cell } \\
\text { phones per } 1000 \text { inhabitants }\end{array}$ & Unchanged \\
\hline & $\begin{array}{l}\text { Science and } \\
\text { Technology }\end{array}$ & INST 3 & $\begin{array}{c}\text { Expenditure on research and } \\
\text { development }\end{array}$ & $\begin{array}{l}\text { Expenditure on research and } \\
\text { development as a \% of GDP }\end{array}$ & Unchanged \\
\hline & $\begin{array}{l}\text { Natural disaster } \\
\text { preparedness } \\
\text { and response }\end{array}$ & INST 4 & $\begin{array}{l}\text { Risks to human and natural } \\
\text { capital }\end{array}$ & $\begin{array}{l}\text { Economic and human } \\
\text { loss due to natural disasters }\end{array}$ & Changed \\
\hline
\end{tabular}

Fig. 3: The sustainability indicators used by the EU and the UN (Source: Eurostat 2001)

\section{IV.3. Measuring the Sustainability of the Information Society}

As the previous two sections have shown there are both indicators for measuring the information society and sustainability. There is a lack of attempts trying to measure the progress towards a sustainable information society. If we assume that important societal changes are taking place and affecting all realms of society that are due to the increasing importance of information, ICTs, networks, and globalization, it is not sufficing to measure the degree to which society is an information society, but one also should develop indicators that show to which degree we live in a sustainable information society that provides human well-being and ecological diversity. The task of a theory of the information society is on the one hand to discuss and advance essence, principles, and dynamics of the new societal formation, and on the other hand to identify aspects and indicators of sustainability that allows stakeholders to develop guidelines for advancing the sustainable character of the information society. The information society indicators that are currently used and discussed focus on quantifying the production, diffusion, and use of ICTs in society, but they frequently lack an explicit inclusion of sustainability issues. Approaches on measuring sustainability discuss broad societal issues, but they frequently lack taking adequately into account issues of information and ICTs. Some of them simply ignore such topics, others only include measurements of computer and Internet diffusion in society. The task at hand is to identify principles, tendencies, opportunities, risks, dimensions, and indicators of a sustainable information society, to assess and develop ideas of how to use information and ICTs in such a way that ecological, economic, social, and institutional sustainability can be advanced, and to work out indicators for measuring the degrees of sustainability of the various dimensions of the information society.

In researching the relationship between information society and sustainability important results have been achieved concerning the ecological dimension (cf. e.g. Alakeson/Aldrich/Goodman/Jorgensen 2003; Hilty et al. 2004a, b, 2005: Hilty/Ruddy 2000). Lorenz Hilty in this context speaks of a sustainable information society (Hilty et al. 2005, Hilty/Ruddy 2000). "Sustainability in the information society is a more recent field of research, which concentrates on the consequences of information and communication technology (ICT) for the objective of sustainable development" (Hility et al. 2005: 38). Thus far sustainable development in the context of information society research has primarily been considered from the ecological perspective. A recent publication entitled "Towards a Sustainable Information Society" acknowledges that sustainability is now a multidimensional concept, but it doesn't give an explicit definition (Servaes/Carpentier 2006: 5-15).

During the last decade there has been a shift from considering sustainability as a purely ecological concept to defining it in broader societal terms. Hence the discourse on ICT, knowledge, and sustainability shouldn't halt at ecological issues. I have argued that there are ecological, technological, economic, 
political, and cultural aspects of sustainability and that goals of sustainability are biological diversity, technological usability, economic wealth for all, political participation and justice for all, and cultural wisdom and unity in diversity management. Information and ICTs pose both new opportunities and risks in all of these subsystems of society, it is antagonistic and produces in parallel various tendencies that run counter to and contradict each other. Table 3 identifies opportunities and risks of the various dimensions of the information society. A sustainable information society is one that advances opportunities and minimizes risks, it is a society that makes use of ICTs and knowledge for fostering a good life for all human beings of current and future generations by strengthening biological diversity, technological usability, economic wealth for all, political participation of all, and cultural wisdom.

Depending on how ICTs are socially designed and applied they can have positive and/or negative effects on society. They can either have positive or destructive effects on the ecosystem, they can be designed in user-friendly ways or not, can be treated as free goods available to all for free or as commodities that are unequally accessed and distributed (the same is true for knowledge), can either support political participation or surveillance, can advance participatory online-media and the plurality of political information and communication or one-dimensional mass media, can foster a higher publication rate and speed in science (scientific online journals and reviews) or have due to the increasing publication speed negative effects on quality standards provided by the peer-review system, can put forward new forms of art (cyberart, electronic art) that involve audience-participation or have negative influences on the authenticity of artworks, they can support more co-operative or more individualized forms of learning and ethics, can foster both cultural diversity or fundamentalism, can have positive or negative effects on health and medical awareness, can advance and socialize or individualize and limit physical activity and games, and they can be helpful in advancing friendships and love or the sowing of hate (as in the case of right-wing extremists using the World Wide Web). In all cases today ICTs and information don't either have solely positive nor solely negative effects, but both positive and negative ones at the same time. There are enabling and constraining tendencies of ICTs and information in society and ecology today, it is a political task to advance and realize opportunities and to avoid risks that are related to ICTs.

\begin{tabular}{|l|l|l|}
\hline Dimension & Quality & $\begin{array}{l}\text { ICT- and Information-related } \\
\text { Opportunities and Risks }\end{array}$ \\
\hline Ecological Sustainability & Biological Diversity & $\begin{array}{l}\text { Ecologically Sustainable vs. } \\
\text { ecologically destructive ICTs }\end{array}$ \\
\hline Technological Sustainability & Usability & $\begin{array}{l}\text { User-oriented, user-friendly, } \\
\text { enabling vs. Unusable, } \\
\text { constraining ICTs }\end{array}$ \\
\hline Economic Sustainability & Wealth for All & $\begin{array}{l}\text { Free knowledge and ICTs vs. } \\
\text { Knowledge and ICTs as } \\
\text { commodity and private property }\end{array}$ \\
\hline $\begin{array}{l}\text { Political Sustainability } \\
\text { Sustainability of: }\end{array}$ & Participation of All & $\begin{array}{l}\text { Participation vs. Control enabled } \\
\text { by ICTs }\end{array}$ \\
\hline Mass Media & Wisdom & $\begin{array}{l}\text { Wisdom vs. False Consciousness } \\
\text { advanced by ICTs }\end{array}$ \\
& Wise Knowledge and Media \\
Science & $\begin{array}{l}\text { Participatory, wise Online- } \\
\text { Journalism vs. Manipulative, one- } \\
\text { dimensional Online-Journalism }\end{array}$ \\
Art & Truth & $\begin{array}{l}\text { Speed vs. Quality of E-Science } \\
\text { Bura Gain and participatory art vs. }\end{array}$ \\
\hline
\end{tabular}




\begin{tabular}{|l|l|l|}
\hline \multicolumn{1}{|l|}{ Education } & $\begin{array}{l}\text { Aura and authenticity loss of } \\
\text { works of art in cyberspace }\end{array}$ \\
Morals & $\begin{array}{l}\text { Literacy and Good Skills } \\
\text { Openness, Unity in Diversity of } \\
\text { Values and Rights } \\
\text { Searning }\end{array}$ & $\begin{array}{l}\text { Open VS. Fundamental } \\
\text { Cyberethics }\end{array}$ \\
Sealth & $\begin{array}{l}\text { Positive vs. Negative effects of } \\
\text { ICTs on health }\end{array}$ \\
Social Relationships & Fitness & $\begin{array}{l}\text { Advancement/socialization vs. } \\
\text { limitation/individualization of } \\
\text { physical activity and games }\end{array}$ \\
Cove and Understanding & Cyberlove vs. Cyberhate \\
\hline
\end{tabular}

Tab. 3: Dimensions of the Sustainability of the Information Society

In table 4 I have for gathered for each dimension of sustainability some indicators that could be used for measuring the degree to which a sustainable information society has been achieved. In the second column I list some important indicators of sustainability, in the third column I list a couple of already existing as well as new indicators for measuring the connection of sustainability with knowledge and ICTs.

\begin{tabular}{|c|c|c|}
\hline System & Sustainable Society Indicators & $\begin{array}{l}\text { Sustainable Information } \\
\text { Society Indicators }\end{array}$ \\
\hline Ecology & $\begin{array}{l}\text { Traditional fuel consumption (\% } \\
\text { of total energy requirements, } \\
\text { UNHDP 2005) } \\
\text { Electricity consumption per } \\
\text { capita (kilowatt-hours, UNHDP } \\
2005 \text { ) } \\
\text { Intensity of material use }{ }^{1} \text { (kgs, } \\
\text { tonnes or m3 per } \$ 1,000 \text { of } \\
\text { GDP, UNDSD 2001) } \\
\text { GDP per unit of energy use } \\
\text { (2000 PPP US\$ per kg of oil } \\
\text { equivalent, UNHDP 2005) } \\
\text { Energy intensity=Energy use per }\end{array}$ & $\begin{array}{l}\text { E-Sustainability Index } 1= \\
\text { Intensity of material use in ICT } \\
\text { and knowledge-based industries } \\
\text { and services (kgs, tonnes or } \mathrm{m}^{3} \\
\text { per } \$ 1,000 \text { of GDP) } \\
\text { E-Sustainability Index } 2= \\
\text { Transport intensity }{ }^{5} \text { of ICT and } \\
\text { knowledge-based industries and } \\
\text { services (in tonne kilometres per } \\
\text { unit of GDP) } \\
\text { (Spangenberg/Bonniot 1998) } \\
\text { E-Sustainability Index } 3= \\
\text { Energy intensity }{ }^{6} \text { of ICT and } \\
\text { knowledge-based industries and } \\
\text { services (in Megajoules per unit }\end{array}$ \\
\hline
\end{tabular}

${ }^{1}$ The quantities of minerals and metals, including primary and secondary (recycled) materials, consumed per unit of real Gross Domestic Product (GDP).

2 Energy consumption for transportation relative to the amount of freight or passengers carried and the distance travelled.

${ }^{3}$ The indicator compares the total forest felling as a percentage of the net annual increment.

${ }^{4}$ This indicator is defined as the number of tonnes of freight transported multiplied by the distance transported, by different modes of transport.

${ }^{5}$ Transport intensity is a measure that relates two key indicators: the volume of freight transport (measured in tonne kilometres, i.e. the number of tonnes of freight transported multiplied by the transport distance) and the economic output (GDP).

${ }^{6}$ Energy intensity is the ratio of total primary energy consumption or final energy consumption to gross domestic product or physical output. 


\begin{tabular}{|c|c|}
\hline $\begin{array}{l}\text { unit of GDP (Megajoules }(\mathrm{mJ}) \\
\text { per } \$ \text {, UNDSD 2001) } \\
\text { Intensity of energy use in the } \\
\text { commercial/service sector } \\
\text { (Megajoules per US } \$(\mathrm{~mJ} / \$) \text { or } \\
\text { megajoules per square meters } \\
\left(\mathrm{mJ} / \mathrm{m}^{2}\right), \text { UNDSD 2001) }\end{array}$ & $\begin{array}{l}\text { of GDP (\$, Euro)) } \\
\text { E-Sustainability Index } 3= \\
\text { Number of business-oriented } \\
\text { teleconferences and electronic } \\
\text { communication events / Number } \\
\text { of business-travels by car or } \\
\text { plane }\end{array}$ \\
\hline $\begin{array}{l}\text { Intensity of energy use in } \\
\text { manufacturing (Megajoules (mJ) } \\
\text { per unit output of the } \\
\text { manufacturing sector in constant } \\
\text { US dollars, UNDSD 2001) }\end{array}$ & $\begin{array}{l}\text { E-Waste index = Amount of non- } \\
\text { recyclable electronic waste per } \\
\text { capita (in tons) } \\
\text { Rate of ICT-Related Waste } \\
\text { recycling and reuse }\end{array}$ \\
\hline $\begin{array}{l}\text { Intensity of energy use in the } \\
\text { residential sector (Gigajoules } \\
\text { (GJ) per capita or GJ per } \\
\text { household, UNDSD 2001) } \\
\text { Intensity of energy use in } \\
\text { transportation }{ }^{2} \text { (Megajoules per } \\
\text { tonne-kilometre (mJ/tonne-km) } \\
\text { for freight, and Megajoules per } \\
\text { passenger-kilometre } \\
\text { (mJ/passenger-km) for } \\
\text { passengers, UNDSD 2001) }\end{array}$ & $\begin{array}{l}\text { E-Traffic Index = Number of } \\
\text { important activities completed } \\
\text { online / Number of important } \\
\text { activities completed by using car } \\
\text { or plane (per capita) }\end{array}$ \\
\hline $\begin{array}{l}\text { Generation of industrial waste } \\
\text { (Tonnes, Eurostat 2001) }\end{array}$ & \\
\hline $\begin{array}{l}\text { Generation and disposal of } \\
\text { municipial waste (Eurostat 2001) }\end{array}$ & \\
\hline $\begin{array}{l}\text { Generation of hazardous wastes } \\
\text { (Metric tonnes or tonnes per unit } \\
\text { of GDP, UNDSD 2001) }\end{array}$ & \\
\hline $\begin{array}{l}\text { Generation of radioactive waste } \\
\text { (cubic metre }\left(\mathrm{m}^{3}\right) \text { per annum, } \\
\text { UNDSD 2001) }\end{array}$ & \\
\hline $\begin{array}{l}\text { Rate of waste recycling and } \\
\text { reuse }(\%, \text { UNDSD 2001) }\end{array}$ & \\
\hline $\begin{array}{l}\text { Distance travelled per capita by } \\
\text { mode of transport (Kilometers } \\
\text { per year, UNDSD 2001) }\end{array}$ & \\
\hline Carbon dioxide em & \\
\hline
\end{tabular}




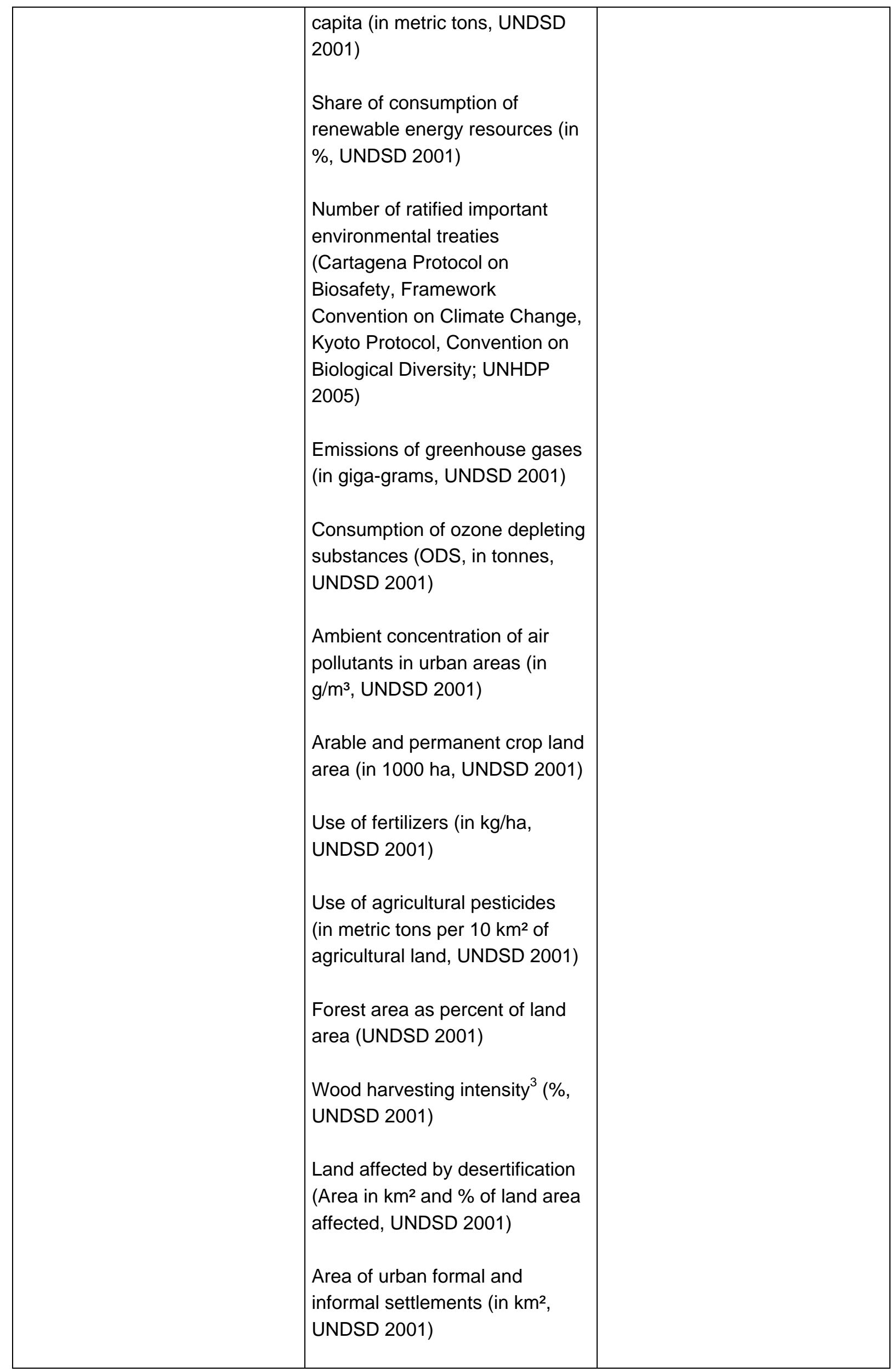




\begin{tabular}{|c|c|c|}
\hline & $\begin{array}{l}\text { Algae concentration in coastal } \\
\text { waters (mg of chlorophyll per } \mathrm{m}^{3} \text {, } \\
\text { UNDSD 2001) } \\
\text { Percent of total population living } \\
\text { in coastal areas (UNDSD 2001) } \\
\text { Annual catch by major species in } \\
\text { fishery (in metric tons, UNDSD } \\
\text { 2001) } \\
\text { Annual withdrawals of ground } \\
\text { and surface water as percent of } \\
\text { total renewable water (UNDSD } \\
\text { 2001) } \\
\text { Biochemical oxygen demand } \\
\text { (BOD) in water bodies (in mg/l of } \\
\text { oxygen consumed in } 5 \text { days at a } \\
\text { constant temperature of } 20^{\circ} \mathrm{C} \text {, } \\
\text { UNDSD 2001) } \\
\text { Concentration of faecal coliforms } \\
\text { in Freshwater (\%, UNDSD 2001) } \\
\text { billion tonne-km, Eurostat } 2001 \text { ) } \\
\text { Area of selected key } \\
\text { Ecosystems (Area (km2 or ha) of } \\
\text { selected ecosystem types; } \\
\text { UNDSD 2001) } \\
\text { Protected area as a percent of } \\
\text { total area (UNDSD } 2001 \text { ) } \\
\text { Abundance of selected key } \\
\text { species (UNDSD } 2001 \text { ) } \\
\text { disposal facilities (Eurostat } \\
2001 \text { ) }\end{array}$ & \\
\hline Technology & $\begin{array}{l}\text { Telephone mainlines (per 1,000 } \\
\text { people, UNHDR 2005) } \\
\text { Research and development } \\
\text { (R\&D) expenditures (\% of GDP, }\end{array}$ & $\begin{array}{l}\text { Internet users (per 1,000 people, } \\
\text { UNHDR 2005) } \\
\text { Number of Internet hosts (per } \\
1000 \text { people, UNHDR 2001) }\end{array}$ \\
\hline
\end{tabular}




\begin{tabular}{|c|c|c|}
\hline & $\begin{array}{l}\text { UNHDR 2005) } \\
\text { Researchers in R\&D (per million } \\
\text { people, UNHDR 2005) } \\
\text { Access to electricity (\% of } \\
\text { households, UNHDR 2001) }\end{array}$ & $\begin{array}{l}\text { Cellular subscribers (per 1,000 } \\
\text { people, UNHDR 2005) } \\
\text { Number of ISDN subscriptions } \\
\text { per thousand inhabitants } \\
\text { (Eurostat 2005) } \\
\text { Usability Index (WWW) = } \\
\text { Number of visited websites } \\
\text { considered having good usability } \\
\text { / Total number of visited } \\
\text { websites } \\
\text { Usability Index } \\
\text { (Telecommunication) = Number } \\
\text { of used telecommunication } \\
\text { devices considered having good } \\
\text { usability per capita / Total } \\
\text { number of used } \\
\text { telecommunication devices per } \\
\text { capita }\end{array}$ \\
\hline Economy & $\begin{array}{l}\text { Poverty rate (\%, national poverty } \\
\text { line) (UNDSD 2001) } \\
\text { Human Poverty Index (HPI-1, } \\
\text { HPI-2, UNHDR 2005) } \\
\text { Population rate surviving on less } \\
\text { than } \$ 1 \text { per day (developing } \\
\text { countries, UNHDR 2005) } \\
\text { Population rate surviving on less } \\
\text { than } \$ 2 \text { per day (developing } \\
\text { countries, UNHDR 2005) } \\
\text { Rate of population below 50\% of } \\
\text { median income (developed } \\
\text { countries, UNHDR 2005) } \\
\text { Population rate surviving on less } \\
\text { than } \$ 4 \text { per day (developed } \\
\text { countries, UNHDR 2005) } \\
\text { Population rate surviving on less } \\
\text { than } \$ 11 \text { per day (developed } \\
\text { countries, UNHDR 2005) } \\
\text { Gini coefficient (measures }\end{array}$ & $\begin{array}{l}\text { Digitial divide index } 1 \text { = Number } \\
\text { of home Internet users / Total } \\
\text { population number } \\
\text { Digital divide index } 2 \text { = Number } \\
\text { of home computer users / Total } \\
\text { population number } \\
\text { Digital divide index } 3 \text { = (Global } \\
\text { number of Internet users * } \\
\text { Number of inhabitants of the } \\
\text { specific country) / (Number of } \\
\text { Internet users in the specific } \\
\text { country * World population) (=the } \\
\text { relationship of the global Internet } \\
\text { penetration rate to the } \\
\text { local/national Internet } \\
\text { penetration rate; the higher the } \\
\text { amount, the higher is the digital } \\
\text { divide in the nation/community } \\
\text { analyzed) } \\
\text { Digital divide index } 4=\text { (Global } \\
\text { number of Internet hosts * } \\
\text { Number of inhabitants of the } \\
\text { specific country) / (Number of } \\
\text { Internet hosts in the specific }\end{array}$ \\
\hline
\end{tabular}




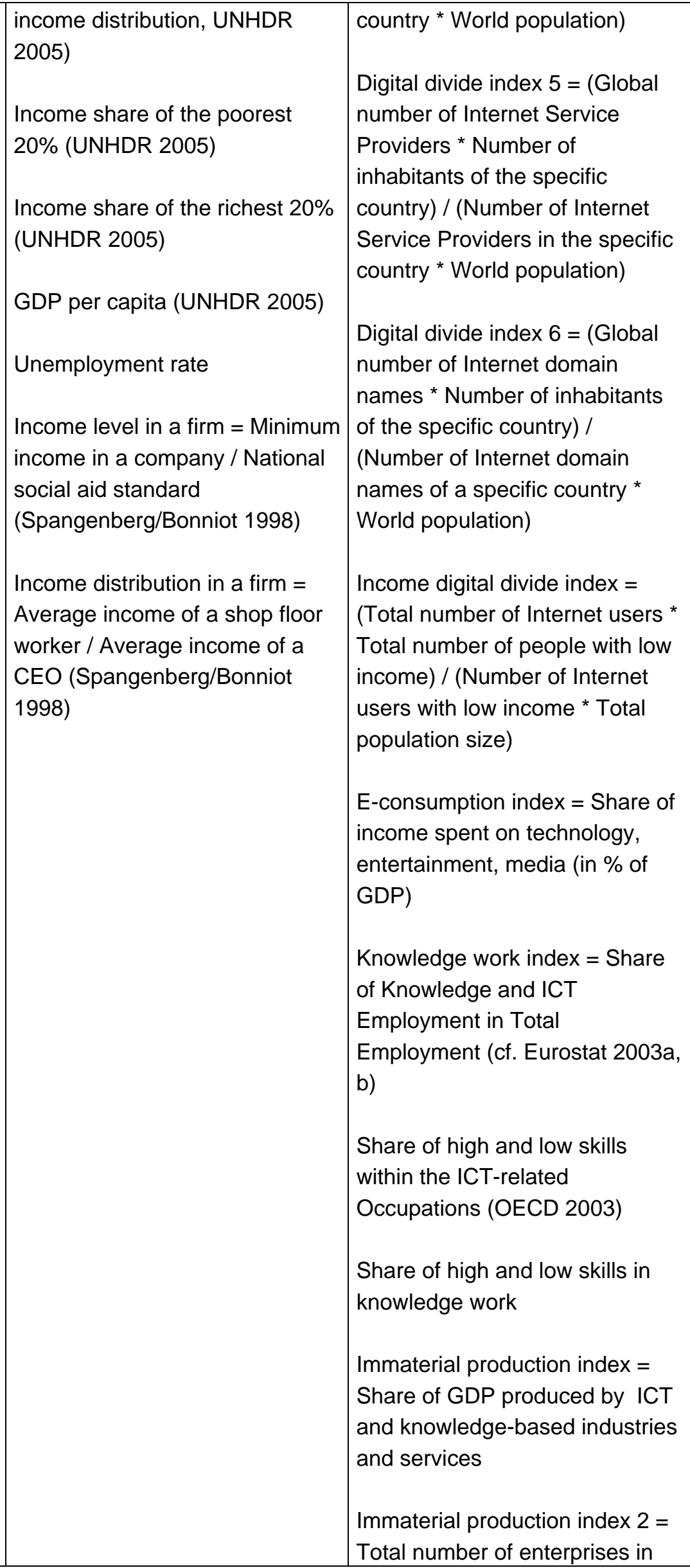




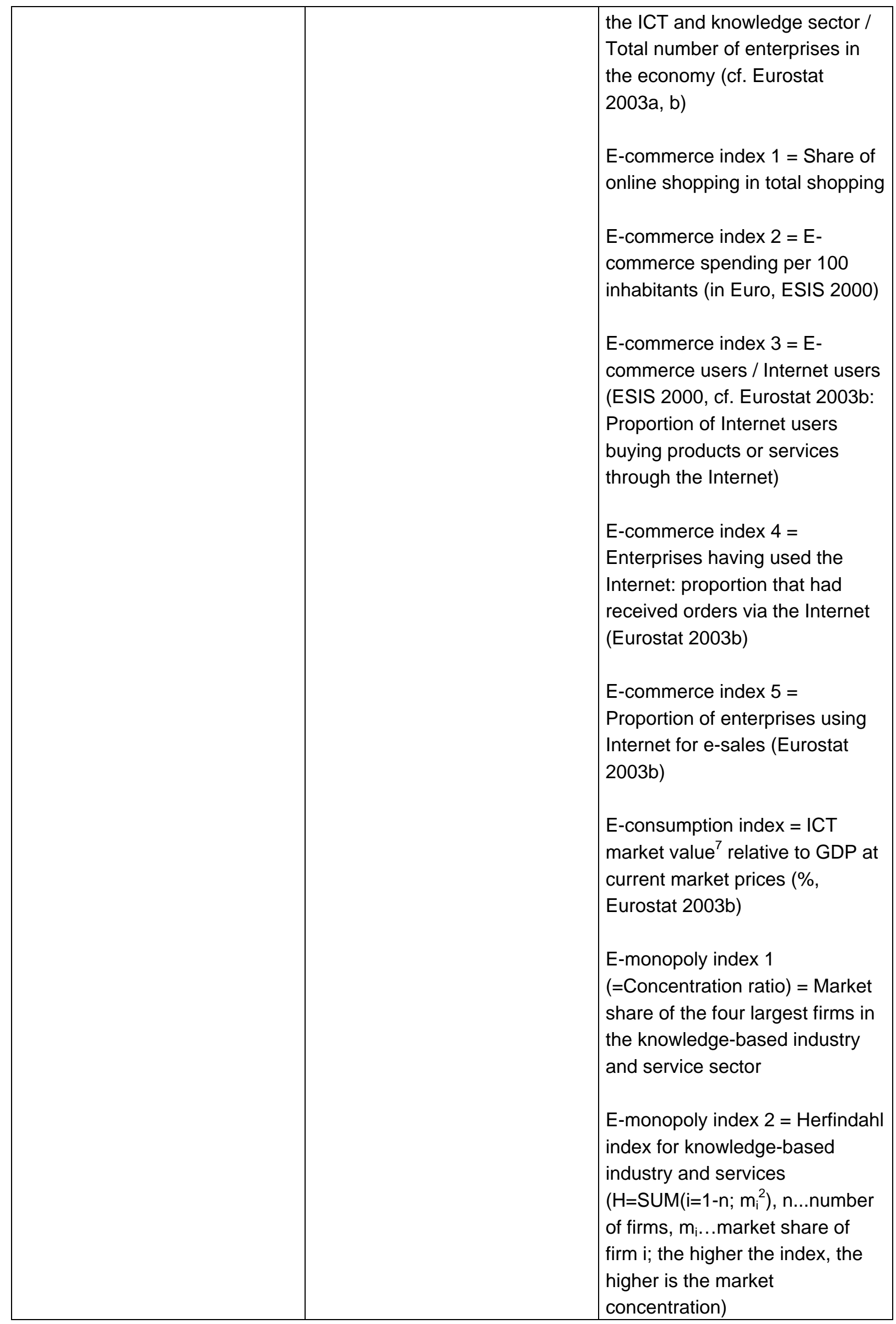

\footnotetext{
${ }^{7}$ The ICT market value represents the total end user spending on ICT equipment and services.
} 


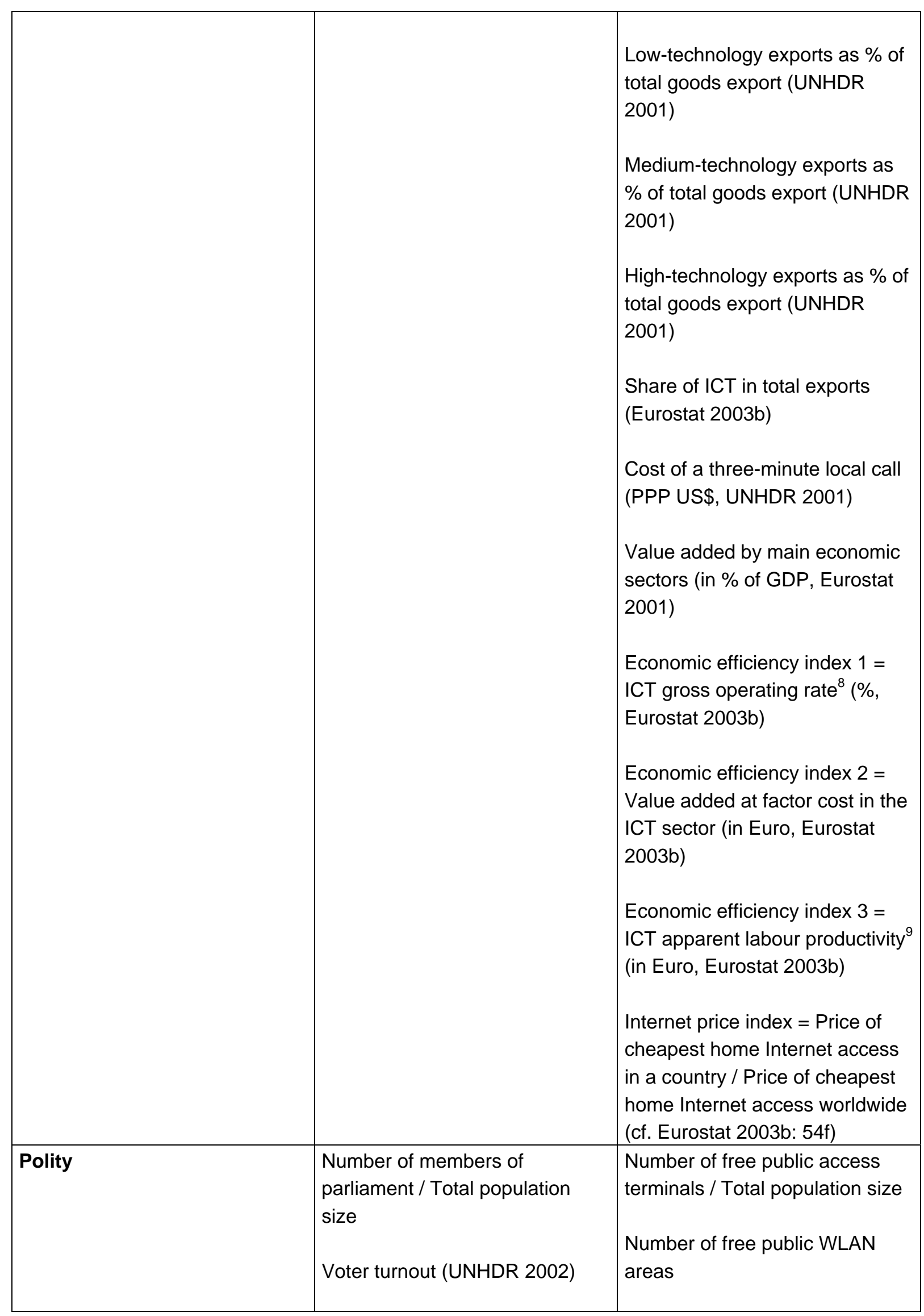

${ }^{8}$ The gross operating rate (GOR) measures profitability by showing how much of the value added is left after the labour factor input has been compensated as a percentage of turnover.

${ }^{9}$ Apparent labour productivity can be measured by how much value added is generated per person employed. 


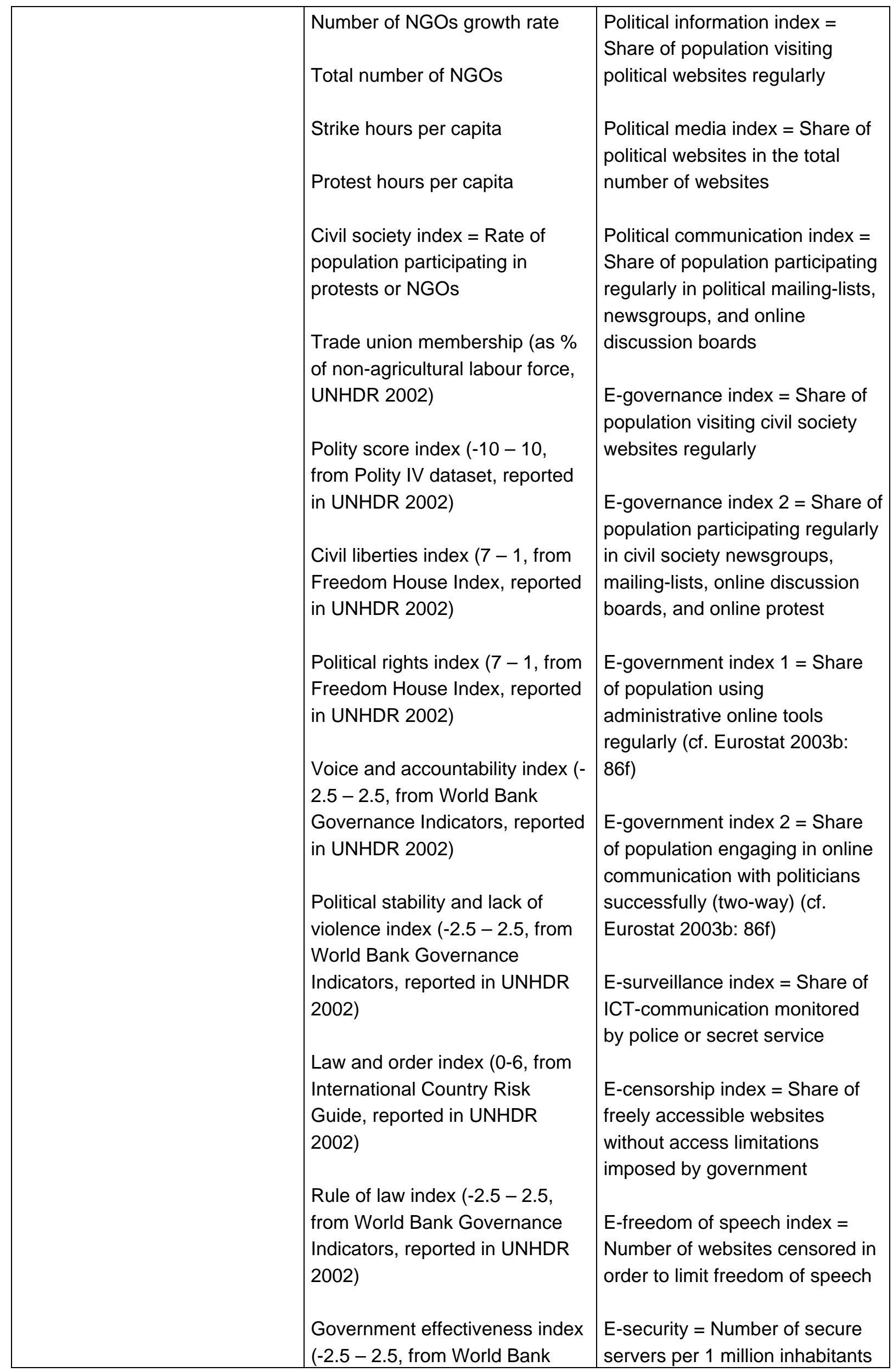




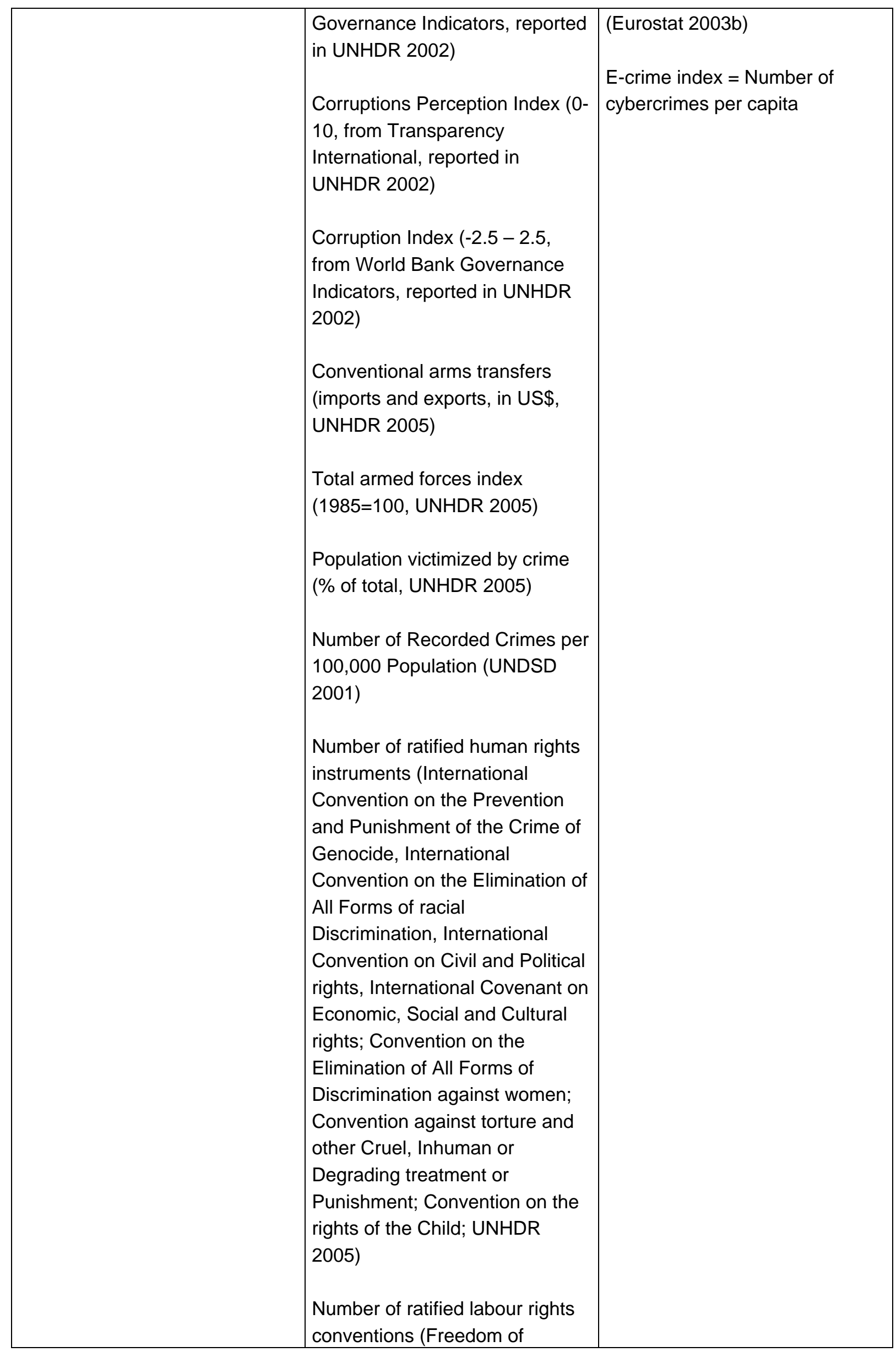




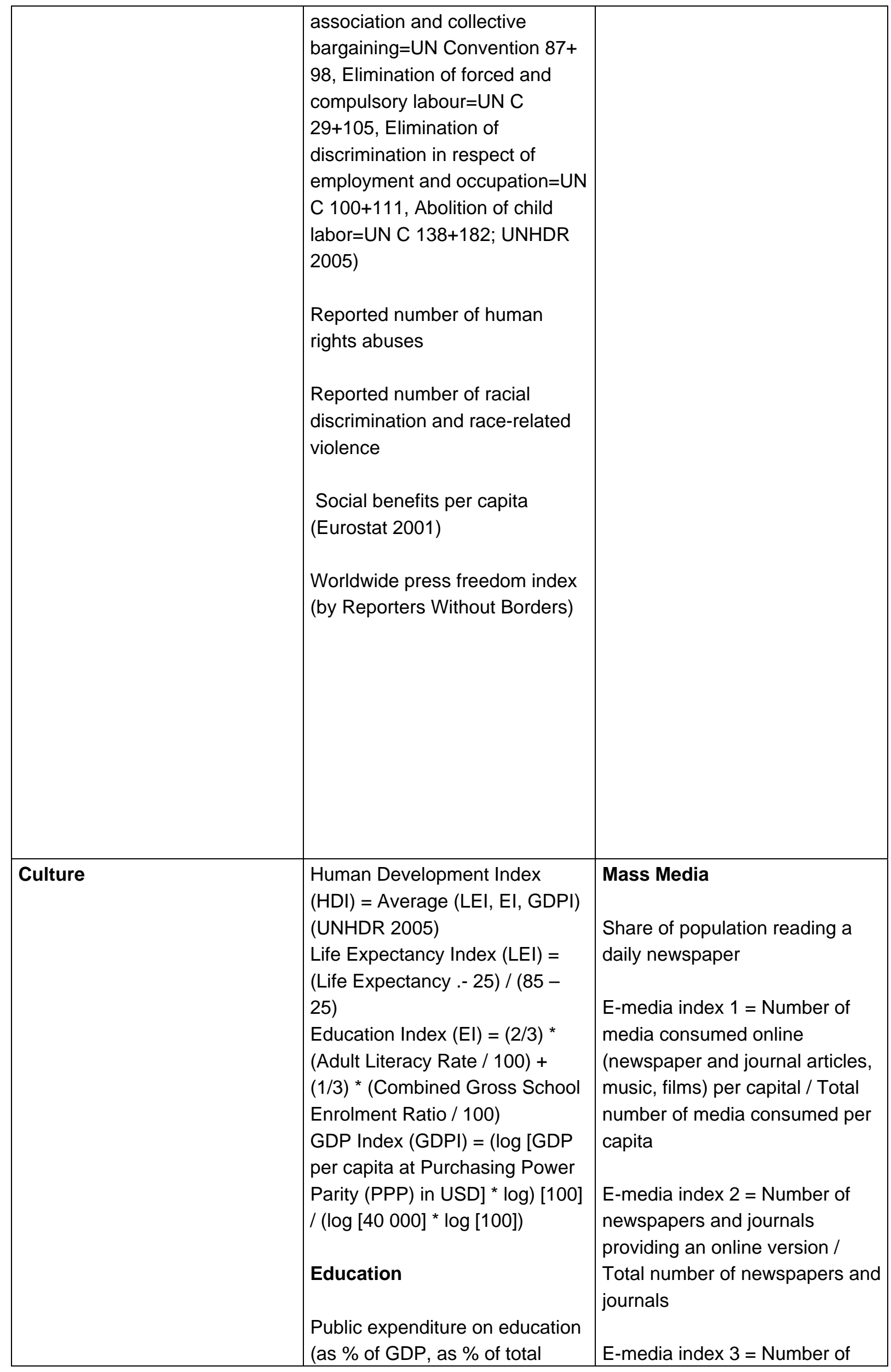




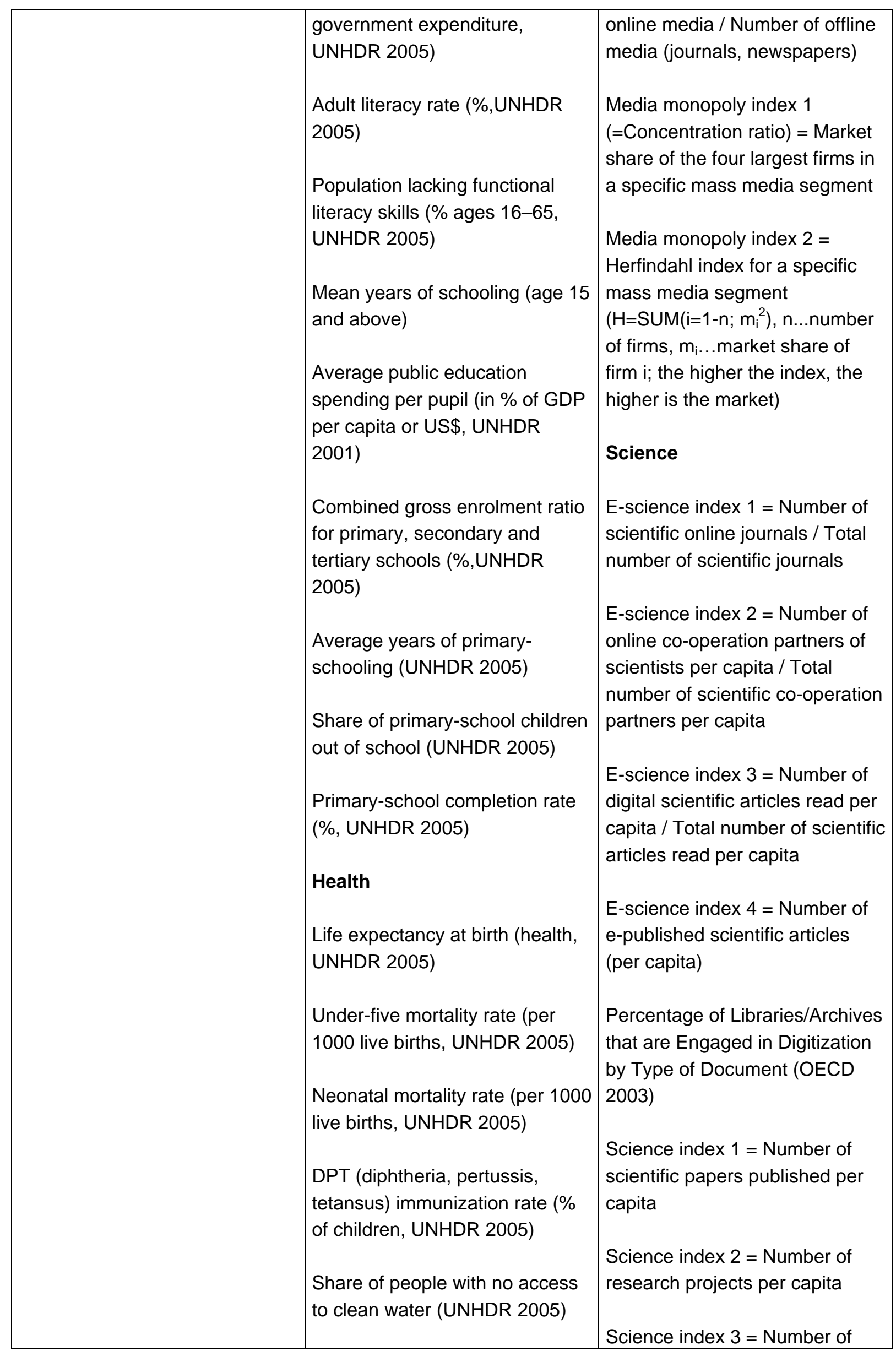




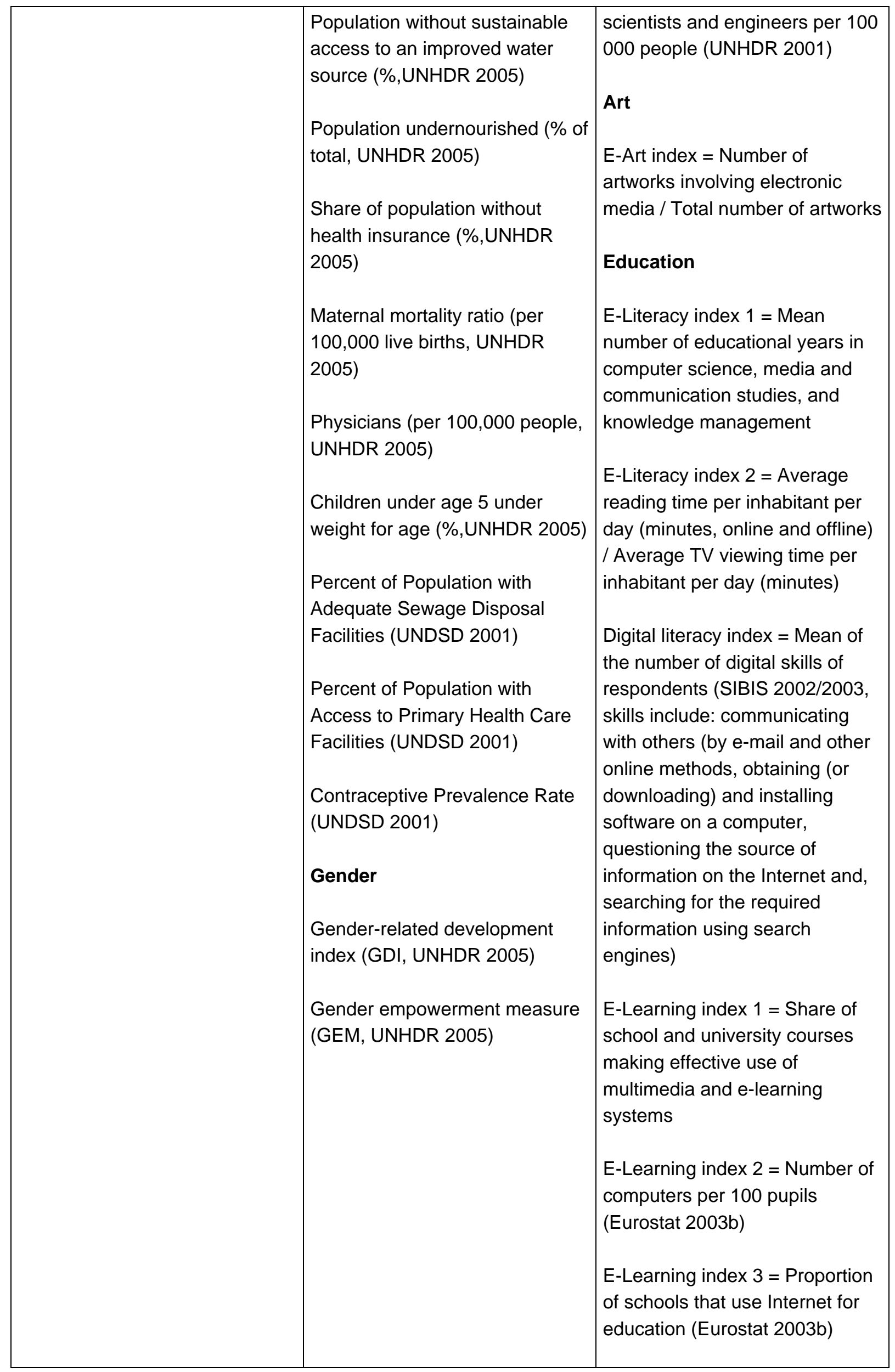




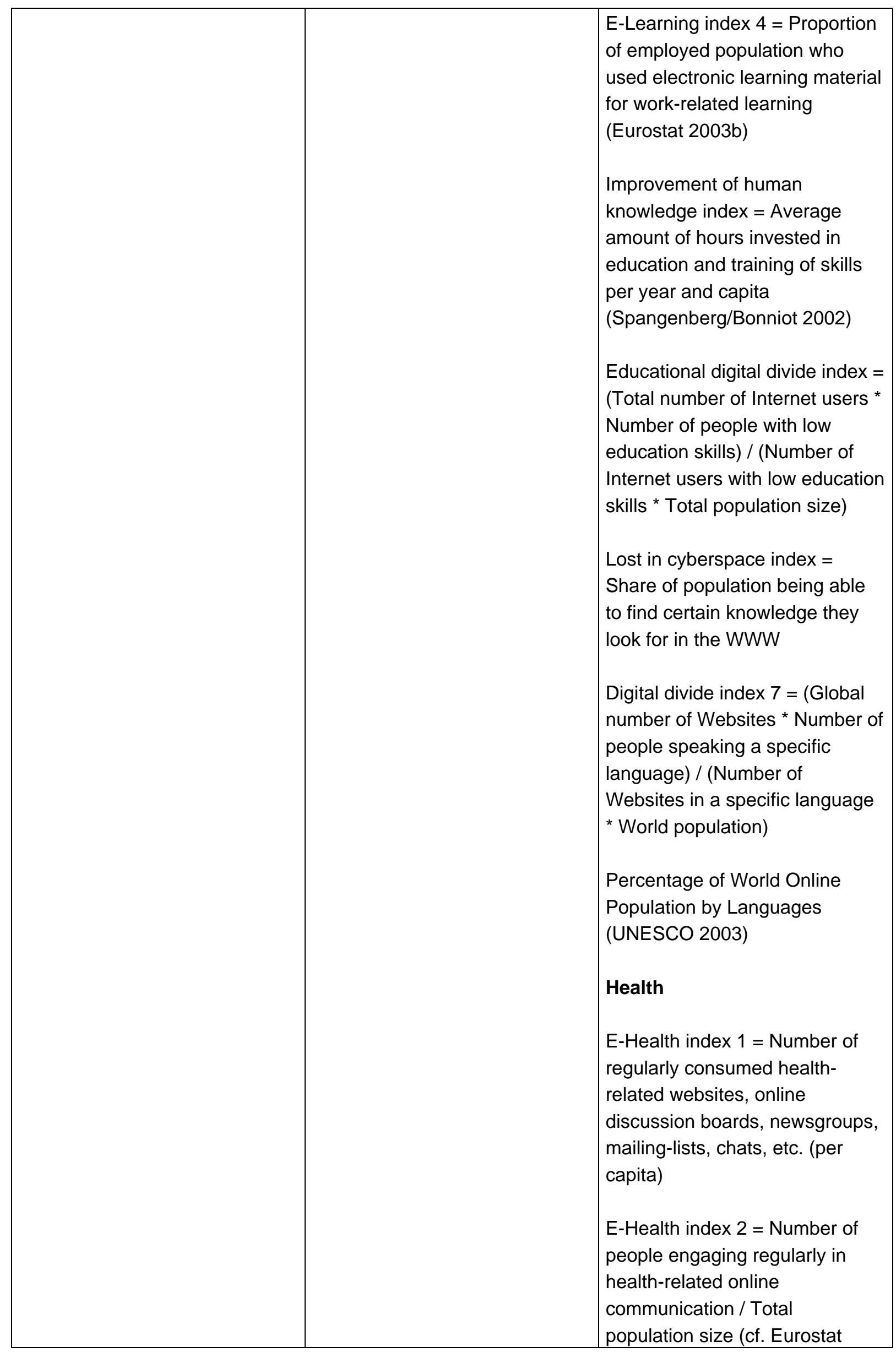




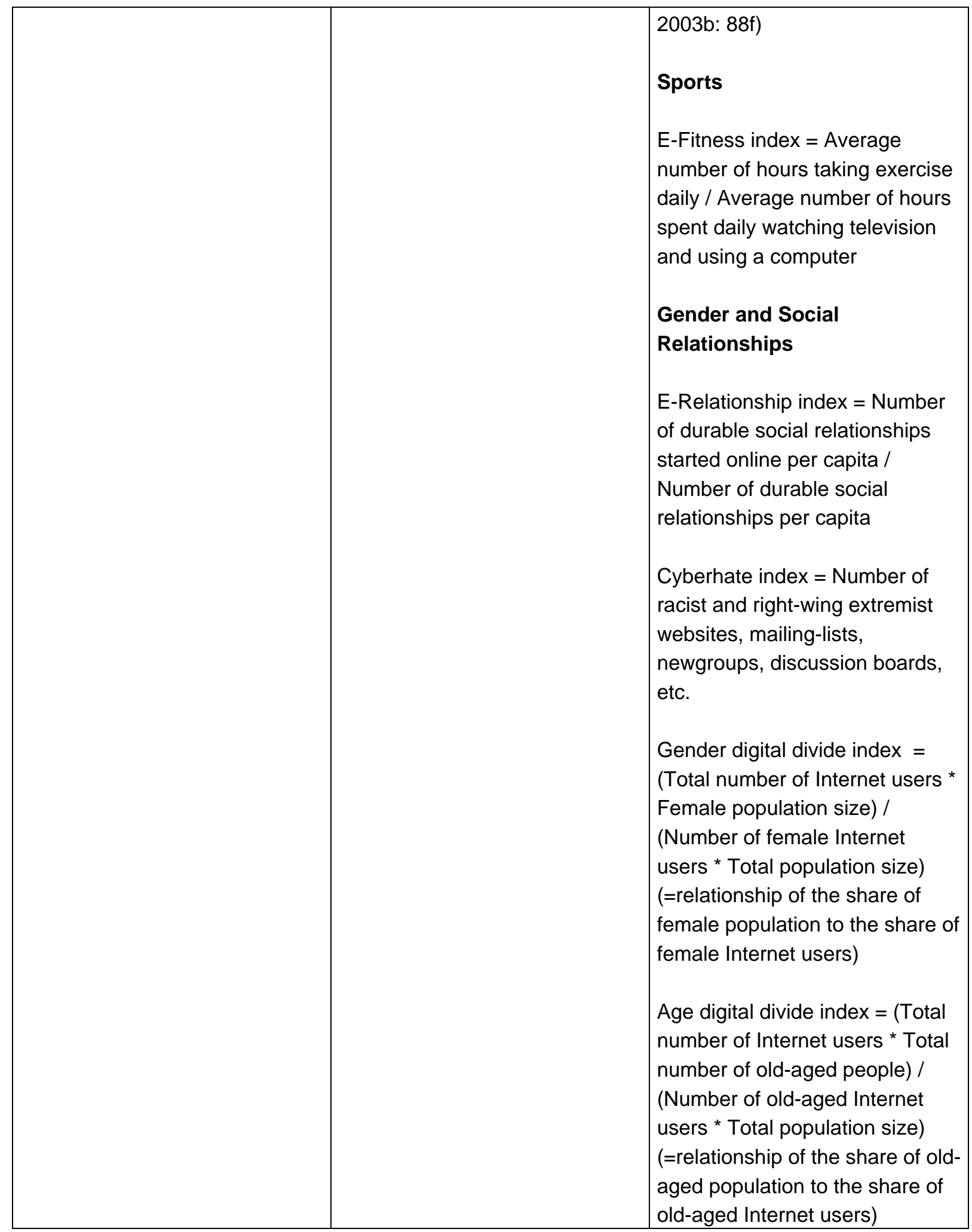

Tab. 4: A Set of Possible Indicators for Measuring the Sustainability of Society and the Information Society

\section{Conclusion}

Based on dialectical thinking one must conceive sustainability as a broad notion that covers both ecological and societal aspects that are mutually connected. A sustainable society requires a sustainable ecosystem and vice versa. The modern mode of production that is based on the logic of accumulation has produced unsustainable patterns of development that continue to shape the information society. The emergence of the information society has put forward both new opportunities and risks for sustainable 
development. A theory of the information society should help analyzing and identifying risks, opportunities, and choices. For doing so a multidimensional concept of sustainability and the sustainable information society as well as concepts for indicators that measure the degree to which a sustainable information society has been achieved are necessary.

\section{References:}

Alakeson, Vidhya/Aldrich, Tim/Goodman, James/Jorgensen, Britt (2003) Making the Net Work. Sustainable Development in a Digital Society. Teddington. Forum for the Future.

Allaby, M. (1988) Dictionary of the Environment. London. MacMillan Press.

Allen, Robert (1980) How to Save the World. London. Kogan Page.

Annan, Kofi (2005) Report of the UN Secretary-General: In larger freedom: towards development, security and human rights for all. United Nations http://www.globalmarshallplan.org/e5095/e5097/e5350/annan report larger freedom 20050321 eng.pdf

Association of South East Asian Nations (ASEAN) The ASEAN Workshop on Measurement of Digital Economy. Ratchathewi, Bangkok. Online: http://www.ecommerce.or.th/project/asean-measurement/measurement report.pdf

Barbier, E. (1987) The Concept of Sustainable Economic Development. In: Environmental Conservation, Vol. 14, No.2.

Barthel, C. et al. (2000) International Climate Policy \& the IT-Sector, Japan \& Germany. Wuppertal. Wuppertal Institute.

Baudrillard, Jean (1983) Simulations. New York. Semiotext(e)

Beck, Ulrich (1986) Die Risikogesellschaft. Frankfurt/Main. Suhrkamp.

Beck, Ulrich (1999) Modern Society as a Risk Society. In: Meja, Volker/Stehr, Nico (Eds.) (1999) The Sociology of Knowledge. 2 Volumes. Cheltenham/Northampton. Edgar Elgar. Vol. 2, pp. 262-277.

Beirat für Wirschafts- und Sozialfragen (2001) Digitale Wirtschaft. Wien. Bundeskammer für Arbeit und Angestellte.

Bell, Daniel (1976) The Coming of Post-Industrial Society. New York. Basic Books.

Benchmarking the Information Society e-Europe Indicators for European Regions (BISER) (2004) BISER eEurope Regions Benchmarking Report. Bonn. empirica $\mathrm{GmbH}$.

Briefs, Ulrich (2000) Ökologische Produktion und Neue Medien. Produkte der Zukunft auf dem Gebiet der Informations- und Kommunikationstechniken. Bonn. Friedrich Ebert Stiftung.

Brown, J. et al. (1988) Global Sustainability: Towards Measurement. In: Environmental Management, Vol 12, No. 2.

Brown, Lester (1981) Building a Sustainable Society. New York. Norton and Company.

Burkett, Paul (2005) Entropy in Ecological Economics: A Marxist Intervention. In: Historical Materialism, Vol. 12, No. 1. pp. 117-152.

Castells, Manuel (2000) The Rise of the Network Society. The Information Age: Economy, Society and Culture Volume 1. Second Edition. Malden. Blackwell.

Castells, Manuel (2004) The Power of Identity. Second Edition. Malden. Blackwell.

Commission of the European Communities (2002b) eEurope 2005: Benchmarking Indicators. Brussels. European Commission.

Commission of the European Communities (2002a) eEurope 2005: An Information Society for All. Action Plan. Brussels. European Commission.

Costanza, R./Wainger, Lisa (1991) Ecological Economics Mending the Earth. Berkeley. North Atlantic Books.

Council of the European Union (2003) Legislative Acts and other Instruments: Council Resolution on the Implementation of the eEurope 2005 Action Plan. Brussels. Council of the European Union.

Coyle, Diane (1997) The Weightless World. Strategies for Managing the Digital Economy. London. Capstone.

Dalal, Barry/Bass, Stephen (2002) Sustainable Development Strategies. A Resource Book. London/Sterling, VA. Earthscan Publications Ltd.

Deutsch, Karl (1983) Soziale und politische Aspekte der Informationsgesellschaft. In: Sonntag, Philipp (Ed.) (1983) Die Zukunft der Informationsgesellschaft. Frankfurt/Main. Haag \& Herchen. pp. 68-88.

Drucker, Peter (1969) The Age of Discontinuity. London. Heinemann.

Dyson, Esther/Gilder, George/Keyworth, George/Toffler, Alvin (1994) Cyberspace and the American Dream: A Magna Carta for the Knowledge Age. In: Future Insight 1.2. The Progress \& Freedom Foundation.

Edwards, Andrés R. (2005) The Sustainability Revolution. Portrait of a Paradigm Shift. Gabriola Islan. New Society Publishers.

Ehrlich, P.R. (1968) The Population Bomb. New York. Balantine.

Elliott, Jennifer A. (1999) Sustainable Development. Second Edition. London/New York. Routledge.

Eurobarometer (2002) Flash Eurobarometer 2002: Internet and the Public at Large. Brussels. European Commission.

Eurobarometer (2000a) Measuring Information Society, 2000. A Eurobarometer survey carried out for the European Commission by INRA (Europe) - European Coordination Office. Brussels. European Commission.

Eurobarometer (2000b) MIS Special Enterprises. Survey organised and managed by the Directorate General, Education and Culture. Brussels. European Commission.

Eurobarometer (2000c) Internet for the General Public. Survey organised and managed by the Directorate General, Education and Culture. Brussels. European Commission. 
Eurobarometer (1998) Measuring Information Society, 1998. A Eurobarometer survey carried out for the European Commission by INRA (Europe) - European Coordination Office. Brussels. European Commission.

Eurobarometer (1997) Measuring Information Society, 1997. A Eurobarometer survey carried out for the European Commission by INRA (Europe) - European Coordination Office. Brussels. European Commission.

European Commission (2002) A European Union Strategy for Sustainable Development. Luxembourg. Office for Official Publications of the European Communities.

European Commission (2001) Consultation Paper for the Preparation of a European Union Strategy for Sustainable Development. http://europa.eu.int/comm/environment/eussd/consultation paper en.pdf

European Environmental Bureau/Friends of Nature International/Friends of the Earth Europe (2001) Indicators for sustainable development. http://www.foeeurope.org/publications/2002/indicators for.htm

European Information Technology Observatory (EITO) (2002) Jahrbuch 2002. Frankfurt/Main. EITO.

European Information Technology Observatory (EITO) (2005) European Information Technology Observatory 2005. Frankfurt/Main. EITO.

European Survey of Information Society (ESIS) (2000) Information Society Indicators in the Member States of the European Union. A report prepared by the ESIS Project Management Support Team: Brussels. European

Eurostat (2003a) Business in Europe. Statistical Pocketbook. Data 1995-2002. Luxembourg: Off. for Official Publ. of the Europ. Communities.

Eurostat (2003b) Information Society Statistics Pocketbook. Luxembourg. Office for Official Publications of the European Communities.

Eurostat (2002) Information Society Statistics - Pocketbook 2002. Luxembourg. Office for Official Publications of the European Communities.

Eurostat (2001) Measuring Progress Towards a More Sustainable Europe. Proposed Indicators for Sustainable Development. Luxembourg. Office for Official Publications of the European Communities.

Eurostat (1997) Indicators of Sustainable Development. A Pilot Study Following the Methodology of the United Nations Commission on Sustainable Development. Luxembourg. Office for Official Publications of the European Communities.

Fleissner, Peter (2005) Commodification, Information, Value and Profit. In: Poiesis \& Praxis: International Journal of Technology Assessment and Ethics of Science. Vol. 3 (2005), published online at: http://dx.doi.org/10.1007/s10202-005-0007-y

Foster, John Bellamy (2002) Ecology Against Capitalism. New York. Monthly Review Press.

Frauenhofer Institut für Systemtechnik und Innovationsforschung (ISI)/Centre for Energy Policy and Economics (CEPE) (2005) Der Einfluss moderner Gerätegenerationen der Informations- und Kommunikationstechnik auf den Energieverbrauch in Deutschland bis zum Jahr 2010. Möglichkeiten zur Erhöhung der Energieeffizienz und zur Energieeinsparung in diesen Bereichen. Abschlussbericht an das BM für Wirtschaft und Arbeit. Karlsruhe/Zürich.

Friends of the Earth: Poverty, justice and the environment. http://www.foe.co.uk/resource/factsheets/poverty justice environment.pdf Friends of the Earth (1998) Tomorrow's World: Britain's share in a Sustainable Future. UK. Earthscan.

Fuchs, Christian (2006) The Self-Organization of Cyberprotest. In: The Internet \& Society 2006. Ashurst. WIT Press. (Forthcoming)

Fuchs, Christian (2005) Wissenskapitalismus und Bedingungsloses Grundeinkommen. Contribution at the Conference "Grundeinkommen 2005“, October 7-9, 2005, Vienna. Online Proceedings: http://www.grundeinkommen2005.org

Fuchs, Christian (2002) Krise und Kritik in der Informationsgesellschaft. Wien/Norderstedt. Libri BOD.

Garland, Christopher (2003) Information Society Statistics. Brussels. Eurostat. KS-NP-03-022-EN-N.

Gladwin, T./Kennelly, J./Krause, T. (1995) Shifting paradigms for sustainable development: Implications for management theory and research. In: Academic Management Review. Vol. 20, No. 4, pp. 874-907.

Global Marshall Plan Initiative (2004) Global Marshall Plan (Author: Franz Josef Radermacher). A Planetary Contract. Hamburg. Global Marshall Plan Foundation.

Goldsmith, E. et al. (Eds.) (1972) Blueprint for Survival. Harmondsworth. Penguin.

Goodland, R./Ledoc, G. (1987) Neoclassical Economics and Principles of Sustainable Development. In: Ecological Modelling. Vol. 38 (1987).

Greenpeace (2002) Corporate Crimes. The need for an international instrument on corporate accountability and liability. Amsterdam. Greenpeace International.

Grote, Andreas (1994) Grüne Rechnung. Das Produkt Computer in der Ökobilanz. In: CT, 10/1996.

Haveman, Robert (1989) Thoughts on the Sustainable Development Concept and the Environmental Effects of Economic Policy. Pari. OECD seminar on "The Economics of Environmental Issues." Paper No. 5. Sept. 25, 1989.

Hilty, Lorenz et al. (2004a) Assessing the Human, Social, and Environmental Risks of Pervasive Computing. In: Human and Ecological Risk Assessment, 10, pp. 853-874.

Hilty, Lorenz et al. (2004b) The Precautionary Principle in the Information Society. In: Human and Ecological Risk Assessment, 10. pp. 787-799.

Hilty, Lorenz et al. (2005) The Precautionary Principle in the Information Society. Effects of Pervasive Computing on Health and Environment. Berne. TA-SWISS, Center for Technology Assessment.

Hilty, Lorenz/Ruddy, Thomas F. (2000) Towards a Sustainable Information Society. In: Informatik/Informatique, No. 4, 2000, pp. 2-.7. Holmberg, John et al (1999) The ecological footprint from a systems perspective of sustainability. In: International Journal of Sustainable Development and World Ecology. Vol. 6. pp. 17-33. 
Hossain, Kamal (1995) Evolving Principles of Sustainable Development and Good Governance. In: Ginther, K./Denters, E./J.I.M. de Waart, Paul (Eds.) (1995) Sustainable Development and Good Governance. Norwell. Kluwer.

Huws, Ursula (2001) Der Mythos der New Economy. In: Das Argument, Vol. 42, No. 5/6. pp. 646-660.

International Conference on Population and Development (2004) Programme of Action. Adopted at the International Conference on Population and Development, Cairo, 5-13 September 1994. United Nations Pupulation Fund (UNFPA).

IUCN (The World Conservation Union)/WWF (World Wide Fund for Nature)/UNEP (United Nations Environment Programme) (1980) The World Conservation Strategy. Gland, Switzerland. IUCN.

IUCN (The World Conservation Union)/WWF (World Wide Fund for Nature)/UNEP (United Nations Environment Programme) (1991) Caring for the Earth. Gland, Switzerland. IUCN.

Junker, Horst/Lang, Corinna V. (2002) Betriebliche Umweltinformatik, Nachhaltigkeit und Informationsgesellschaft. In: Floyd, Christiane/Fuchs, Christian/Hofkirchner, Wolfgang (Eds.) Stufen zur Informationsgesellschaft Festschrift zum 65. Geburtstag von Klaus Fuchs-Kittowski. Frankfurt/Main. Peter Lang. pp. 349-372.

Kelly, Kevin (1999) New Rules for the New Economy. New York. Viking.

Kuhndt, M. et al. (2003) Project Theme Report: Virtual Dematerialisation. eBusiness and Factor X. Online: http://www.digitaleu.org/uploadstore/theme reports/dematerial report.pdf

Leadbeater, Charles (2000) The Weightless Society. New York. Texere Publishing Ltd.

Machlup, Fritz (1962) The Production and Distribution of Knowledge in the United States. Princeton. Princeton University Press.

Mansell, Robin/Wehn, Uta (Eds.) (1998) Knowledge Societies. Information Technology for Sustainable Development. Oxford. Oxford University Press.

Markandya, Anil/Pearce, David (1988) Natural Environments and the Social Rate of Discount. In: Project Appraisal. Vol. 3 , No.1.

Marletta, Piercarlo et al. (2004) The Environmental Impact of ISTs. E-Living Project Report. Online: http://www.eurescom.de/eliving/deliverables/e-liv-D14-Ch3-Environment.pdf

McCormick, John (1991) Reclaiming Paradise. Bloomington. Indiana University Press.

Meadows, D.H. et al. (1972) The Limits to Growth. New York. Universe Books.

Meadows, Donella et.al. (1992) Beyond the Limits. Post Mills. Chelsea Green Publishing.

Mesenbourg, Thomas L. (2000) Measuring Electronic Business: Definitions, Underlying Concepts, and Measurement Plans. Online: http://www.census.gov/epcd/www/ebusines.htm

Mettler, Peter H. (1997) Sustainable Technology - Sustainability of What? FUTU Publication 3/97. Finland Futures Research Centre. Online: http://www.tukkk.fi/tutu/Julkaisut/futu/FUTU 3 97.pdf

Munasinghe, Mohan/Shearer, Walter (1995) An Introduction to the Definition and Measurement of Biogeophysical Sustainability. In: Munasinghe, Mohan/Shearer, Walter (Eds.) (1995) Defining and Measuring Sustainability: The Biogeophysical Foundations. Washington, D.C. World Bank.

Munro, David (1995) Sustainability: Rhetoric or Reality. In: Trzyna, T. (Ed.) (1995) A Sustainable World: Defining and Measuring Sustainable Development. Sacramento. California Institute for Public Affairs.

Norgaard, Richard (1992) Sustainability of the Economics of Assuring Assets for Future Generations. World Bank, Asia Regional Office, Working Paper Series No. 832.

OECD (1981) Information Activities, Electronics and Telecommunications Technologies: Impact on Employment, Growth and Trade. Paris. OECD.

OECD (1986) Trends in The Information Economy. Paris. OECD.

OECD (1994) Environmental Indicators. OECD Core Set. Paris. OECD.

OECD (2002) Measuring the Information Economy. Paris. OECD.

OECD (2004) OECD work on measuring the Information Society. Paper submitted to the 19th meeting of the Voorburg Group on Services Statistics, held in Ottawa, Canada, September 27 to October 1, 2004. http://www.oecd.org/dataoecd/6/0/33809872.pdf Opschoor, Hans/Reijnders, Lucas (1991) Indicators of Sustainable Development: An Overview. In: Kuik, Onno/Verbruggen, Harman (Eds.) (1991) In Search of Indicators of Sustainable Development. Norwell. Kluwer.

Otto, Peter/Sonntag, Philipp (1985) Wege in die Informationsgesellschaft. München. dtv.

Pearce, David et al. (1989) Blueprint for a Green Economy. London. Earthscan Publications.

Porat, Marc (1977) The Information Economy. Washington, DC. US Department of Commerce.

Prescott-Allen, Robbert (1999) System Assessment Method. Origins and Key Features. Washington, DC. World Conservation Union. President's Council on Sustainable Development (1999) Towards a Sustainable America: Advancing Prosperity, Opportunity, and a Healthy Environment for the 21st Century. http://clinton4.nara.gov/media/pdf/tsa.pdf

Quah, Danny T. (1999) The Weightless Economy in Growth. In: The Business Economist. Vol. 30. No. 1. pp. 40-53.

Redefining Progress (2004) The Genuine Progress Indicator. 1950-2002. Redefining Progress (http://www.redefiningprogress.org)

Richta, Radovan (1977) The Scientific and Technological Revolution and the Prospects of Social Development. In: Dahrendorf, Ralf (Ed.) (1977) Scientific-Technological Revolution. Social Aspects. London. Sage. pp. 25-72.

Schallaböck, Karl Otto et al. (2003) Telework and Sustainable Development. Online: http://www.forumforthefuture.org.uk/uploadstore/GeSI case study.pdf

Schultink, G. (1992) Evaluation of Sustainable Development Alternatives: Relevant Concepts, Resource Assessment, Approaches and Comparative Spatial Indicators. In: International Journal of Environmental Studies. Vol. 41, pp. 203-224. 
Segnestam, Lisa (2002) Indicators of Environment and Sustainable Development. Theories and Practical Experience. Washington, DC. World Bank.

Serageldin, Ismail (1995) The Human Face of the Urban Environment. In: Serageldin, Ismail et al. (Eds.) (1995) Proceedings of the Second Annual World Bank Conference on Environmentally Sustainable Development: The Human Face of the Urban Environment. Washington, D.C., September 19-21, 1994. Washington, D.C. World Bank. pp. 16-20.

Servaes, Jan/Carpentier, Nico (Eds.) (2006) Towards a Sustainable Information Society. Deconstructing WSIS. Bristol. Intellect.

Solomon, Allan (1990) Toward Ecological Sustainability in Europe (Climate, Water Resources, Soils, and Biota). IIASA Research Report RR-90-006. Laxenburg. IIASA.

Spangenberg, Joachim/Bonniot, Odile (1998) Sustainability Indicators - A Compass on the Road towards Sustainability. Wuppertal Paper No. 81. Wuppertal. Wuppertal Institut für Klima, Umwelt, Energie.

Spangenberg, Joachim et al. (2002) Sustainability Indicators for the Knowledge-Based Society. Measuring the Sustainability of the Information Society. In: Futura, 2/02, pp. 85-95.

Statistical Indicators for Benchmarking the Information Society (SIBIS) SIBIS Pocket Book 2002/2003. Bonn. empirica GmbH.

Stehr, Nico (1994) Arbeit, Eigentum und Wissen. Frankfurt/Main. Suhrkamp.

Stehr, Nico (2002) A World Made of Knowledge. Lecture at the Conference "New Knowledge and New Consciousness in the Era of the Knowledge Society", Budapest, January 31st 2002. Online: http://www.crsi.mq.edu.au/pdfworddocs/worldknowledge.pdf

TAU/EMAIL (2001) Towards environmental pressure indicators for the EU. Second edition. TAU Consultora Ambiental and Environment Management And Information Liaison.

Tolba, Mustafa (1987) Sustainable Development - Constraints and Opportunities. London. Butterworth.

Touraine, Alain (1988) Return of the Actor. Minneapolis. University of Minnesota Press.

Türk, Volker et al. (2003) The Social and Environmental Impacts of Digital Music. A Case Study with EMI. Wuppertal Institute.

United Nations Commission for Sustainable Development (UNCSD) (1996) Indicators of Sustainable Development Framework and Methodologies. New York. United Nations.

United Nations Conference on Environment \& Development (1992a) Agenda 21. Adopted at the United Nations Conference on Environment \& Development, Rio de Janeiro, Brazil, 3-14 June 1992.

http://www.sidsnet.org/docshare/other/Agenda21 UNCED.pdf

United Nations Conference on Environment \& Development (1992b) Rio Declaration on Environment and Development. Adopted at the United Nations Conference on Environment \& Development, Rio de Janeiro, Brazil, 3-14 June 1992.

United Nations Conference on Trade and Development (UNCTAD) (2003) Information Society Measurements: The Case of EBusiness. Background paper by the UNCTAD secretariat forthe Expert Meeting of E-Measurement, 8-10 September 2003. Online: http://www.unctad.org/en/docs//c3em19d2 en.pdf

United Nations Conference on Trade and Development (UNCTAD) (2004) E-Commerce and Development Report 2004. New York/Geneva. United Nations. Online: http://www.unctad.org/en/docs/ecdr2004 en.pdf

United Nations Division for Sustainable Development (UNDSD) (2001) Indicators of Sustainable Development: Guidelines and Methodologies. New York. United Nations.

United Nations Educational, Scientific and Cultural Organization (UNESCO) Institute for Statistics (2003) Measuring and Monitoring the Information and Knowledge Societies: A Statistical Challenge. Paris. UNESCO.

United Nations Human Development Report (2005) UNHDP 2005. New York/Oxford. United Nations Development Programme (UNDP).

United Nations Human Development Report (2002) UNHDP 2002. New York/Oxford. United Nations Development Programme (UNDP).

United Nations Human Development Report (2001) UNHDP 2001. New York/Oxford. United Nations Development Programme (UNDP).

United Nations Statistical Office (1992) SNA Draft Handbook on Integrated Environmental and Economic Accounting. New York. UN Publications.

United Nations (2005) The Millennium Development Goals Report 2005. New York. United Nations.

United Nations (2000) United Nations Millennium Declaration. http://www.globalmarshallplan.org/e5095/e5097/e5975/millennium declaration eng.pdf

Virtual Research and Development Centre (2001) Livestock and Environment Toolbox. http://lead.virtualcentre.org/en/dec/toolbox/homepage.htm

Winograd, Michael (1995) Environmental Indicators for Latin America and the Caribbean. In: Trzyna, T. (Ed.) (1995) A Sustainable World: Defining and Measuring Sustainable Development. Sacramento. California Institute for Public Affairs.

World Bank (2005a) Focus on Sustainability 2004. Washington, DC. World Bank.

World Bank (2005b) World Development Indicators 2005. Washington, DC. World Bank.

World Bank (1992) World Development Report, 1992: Development and the Environment. Oxford. Oxford University Press. World Commission on Environment and Development (WCED) (1987) Our Common Future. Oxford. Oxford University Press. World Economic Forum (2000) Pilot Environmental Sustainability Index. Davos. WEF. 
World Resource Institute (WRI) (2000) The Weight of Nations. Material Outflows from Industrial Economies. Developing Environmental Indicators. Washington, DC. WRI.

World Summit on Sustainable Development (2002a) The Jo'burg Memo. Fairness in a Fragile World. Berlin. Heinrich Böll Foundation World Summit on Sustainable Development (2002b) Report of the World Summit Sustainable Development. New York. United Nations.

World Summit on the Information Society (WSIS) (2005) WSIS Thematic Meeting on "Measuring the Information Society". Geneva, 7-9 February 2005. Online: http://www.itu.int/wsis/docs2/thematic/unctad/final-conclusions.PDF World Summit on the Information Society (WSIS) (2003a) Declaration of Principles. Building the Information Society: A Global Challenge in the New Millennium Online: http://www.itu.int/wsis/docs/geneva/official/dop.html

World Summit on the Information Society (WSIS) (2003b) Plan of Action. Online: http://www.itu.int/wsis/docs/geneva/official/poa.html WWF/NEF/WCMC (1999) Living Planet Report 1999. Gland. Switzerland. 